University of Nebraska - Lincoln

DigitalCommons@University of Nebraska - Lincoln

USDA Wildlife Services - Staff Publications

U.S. Department of Agriculture: Animal and Plant Health Inspection Service

$7-1-2021$

\title{
Risks of introduction and economic consequences associated with African swine fever, classical swine fever and foot-and-mouth disease: A review of the literature
}

\author{
Vienna Brown \\ USDA APHIS Wildlife Services, vienna.r.brown@usda.gov \\ Ryan S. Miller \\ USDA Centers for Epidemiology and Animal Health \\ Sophie C. McKee \\ USDA Animal and Plant Health Inspection Service (APHIS) \\ Karina H. Ernst \\ USDA Animal and Plant Health Inspection Service (APHIS)
}

Fidore this _anepeqditional works at: https://digitalcommons.unl.edu/icwdm_usdanwrc

¿Paftipaleand Plant Health Inspection Service(ARHIS)

Policy Commons, Other Environmental Sciences Commons, Other Veterinary Medicine Commons,

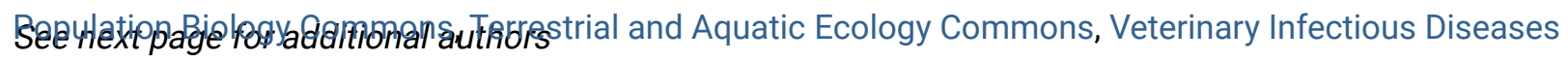

Commons, Veterinary Microbiology and Immunobiology Commons, Veterinary Preventive Medicine,

Epidemiology, and Public Health Commons, and the Zoology Commons

Brown, Vienna; Miller, Ryan S.; McKee, Sophie C.; Ernst, Karina H.; Didero, Nicole M.; Maison, Rachel M.; Grady, Meredith J.; and Shwiff, Stephanie A., "Risks of introduction and economic consequences associated with African swine fever, classical swine fever and foot-and-mouth disease: A review of the literature" (2021). USDA Wildlife Services - Staff Publications. 2489.

https://digitalcommons.unl.edu/icwdm_usdanwrc/2489

This Article is brought to you for free and open access by the U.S. Department of Agriculture: Animal and Plant Health Inspection Service at DigitalCommons@University of Nebraska - Lincoln. It has been accepted for inclusion in USDA Wildlife Services - Staff Publications by an authorized administrator of DigitalCommons@University of Nebraska - Lincoln. 


\section{Authors}

Vienna Brown, Ryan S. Miller, Sophie C. McKee, Karina H. Ernst, Nicole M. Didero, Rachel M. Maison, Meredith J. Grady, and Stephanie A. Shwiff 


\title{
Risks of introduction and economic consequences associated with African swine fever, classical swine fever and foot-and- mouth disease: A review of the literature
}

\author{
Vienna R. Brown ${ }^{1}$ (D) | Ryan S. Miller ${ }^{2}$ | Sophie C. McKee ${ }^{1,3}$ | Karina H. Ernst ${ }^{1,3}$ | \\ Nicole M. Didero ${ }^{1,3}$ | Rachel M. Maison ${ }^{4}$ | Meredith J. Grady ${ }^{5}$ Stephanie A. Shwiff ${ }^{6}$
}

${ }^{1}$ National Feral Swine Damage Management Program, United States Department of Agriculture, Animal and Plant Health Inspection Service, Fort Collins, CO, USA

${ }^{2}$ Center for Epidemiology and Animal Health, United States Department of Agriculture, Animal and Plant Health Inspection Service, Veterinary Services, Fort Collins, CO, USA

${ }^{3}$ Department of Economics, Colorado State University, Fort Collins, CO, USA

${ }^{4}$ Department of Biomedical Sciences, Colorado State University, Fort Collins, CO, USA

${ }^{5}$ Human Dimensions of Natural Resources Department, Colorado State University, Fort Collins, CO, USA

${ }^{6}$ National Wildlife Research Center, United States Department of Agriculture, Animal and Plant Health Inspection Service, Fort Collins, CO, USA

\section{Correspondence}

Vienna Brown, National Feral Swine Damage Management Program, United States

Department of Agriculture, Animal and Plant Health Inspection Service, Fort Collins, CO, USA.

Email: vienna.r.brown@usda.gov

Funding information

U.S. Department of Agriculture; Animal and

Plant Health Inspection Service

\begin{abstract}
African swine fever (ASF), classical swine fever (CSF) and foot-and-mouth disease (FMD) are considered to be three of the most detrimental animal diseases and are currently foreign to the U.S. Emerging and re-emerging pathogens can have tremendous impacts in terms of livestock morbidity and mortality events, production losses, forced trade restrictions, and costs associated with treatment and control. The United States is the world's top producer of beef for domestic and export use and the world's third-largest producer and consumer of pork and pork products; it has also recently been either the world's largest or second largest exporter of pork and pork products. Understanding the routes of introduction into the United States and the potential economic impact of each pathogen are crucial to (a) allocate resources to prevent routes of introduction that are believed to be more probable, (b) evaluate cost and efficacy of control methods and (c) ensure that protections are enacted to minimize impact to the most vulnerable industries. With two scoping literature reviews, pulled from global data, this study assesses the risk posed by each disease in the event of a viral introduction into the United States and illustrates what is known about the economic costs and losses associated with an outbreak.
\end{abstract}

\section{KEYWORDS}

domestic livestock, economic impact, feral swine, foreign animal diseases, risk assessment

\section{1 | INTRODUCTION}

Domestic livestock production plays a vital role in human health and nutrition, food security, rural poverty reduction and overall agronomic health (Randolph et al., 2007; Tomley \& Shirley, 2009). The Food and Agriculture Organization (FAO) estimates that $40 \%$ of the global value of agricultural output is provided by livestock and 1.3 billion people are dependent on livestock for their livelihoods and food security (FAO, 2019a). Emerging and re-emerging pathogens pose a significant threat to livestock industries across the globe, as they can have serious impacts in terms of livestock morbidity and mortality, production losses, consumer demand and costs associated with treatment and control. Some of the most challenging and economically burdensome diseases are those transmitted between wildlife and domestic animals (Miller et al., 2017). Diseases transmitted at the domestic animal-wildlife interface are increasingly challenging 
veterinary health systems with African swine fever (ASF), classical swine fever (CSF) and foot-and-mouth disease (FMD) being three of the most concerning among animal diseases (OIE, 2019). Globally, between 1995 and 2005, the number of outbreaks of these three diseases reached all-time maximums (Figure 1) and has continued to be important animal diseases of economic concern (OIE, 2019).

Disease control measures such as movement bans, culling and vaccination (when available) can be used to reduce the frequency of disease already present in a population by eliminating causes of disease or reducing them to levels of little or no consequence. Analysis of the effectiveness of a disease mitigation strategy is difficult because of inherent uncertainties about the likelihood of disease outbreak and spread parameters (Elbakidze et al., 2009). Further, the ideal cost-minimizing strategies (determined in either ex-ante or ex-post analysis) also depend on relative costs, ancillary benefits and effectiveness of mitigation strategies (Elbakidze \& McCarl, 2006). For these reasons, 'explicit risk-based investigation' (Elbakidze et al., 2009, p. 932) of mitigation of these three diseases are necessary to inform the possible outbreak costs and benefits of mitigation. Thus, a comprehensive understanding of the risks and consequences associated with a potential outbreak of ASF, CSF and/ or FMD is crucial in order to (a) allocate resources to prevent routes of introduction that are believed to be more probable, (b) consider costs and efficacy of control methods and (c) ensure that appropriate mitigation tactics are put in place to minimize impact to the most vulnerable industries. Here, we illustrate the findings of two separate scoping reviews of global literature to identify epidemiological risks, economic measures and scientific gaps for ASF, CSF and FMD.
African swine fever virus (ASFV), a large, double-stranded DNA virus in the Asfarviridae family, is the causative agent of African swine fever. This virus is believed to have evolved in southern and eastern Africa (Penrith, 2009) as a sylvatic cycle exists between warthogs (Phacochoerus africanus) and soft ticks (Ornithodoros; Bakkes et al., 2018). While asymptomatic in warthogs, ASF is a haemorrhagic disease that can cause mortality nearing $100 \%$ in susceptible populations of domestic swine and wild boar (Blome et al., 2013). In 2007, ASFV was introduced to the Caucuses region and subsequently spread throughout Europe and Asia infecting domestic and wild pigs. In the fall of 2018, the virus was introduced to China and has spread rampantly throughout Southeast Asia (FAO, 2019b; Le et al., 2019; Zhou et al., 2018).

Classical swine fever virus (CSFV) is a pestivirus which is the causative agent of classical swine fever. Infection can take several forms (acute, chronic or prenatal) depending on the virus strain and host immune status, which is heavily influenced by age (Moennig, 2000). Clinical signs can range from acute death to non-specific signs, including fever, anorexia, lethargy, respiratory signs, conjunctivitis, diarrhoea and central nervous system involvement (Brown \& Bevins, 2018a). Although CSFV is often fatal, death may or may not follow imminently. Neonatal piglets infected with CSFV in utero may be aborted or stillborn or demonstrate congenital signs soon after birth resulting in death, depending on when in utero the foetus was exposed. Classical swine fever was eradicated from the United States in 1976 after an official eradication scheme began in 1961 (Edwards et al., 2000). Presently, the virus is endemic in several countries in South and Central America, Asia, and parts

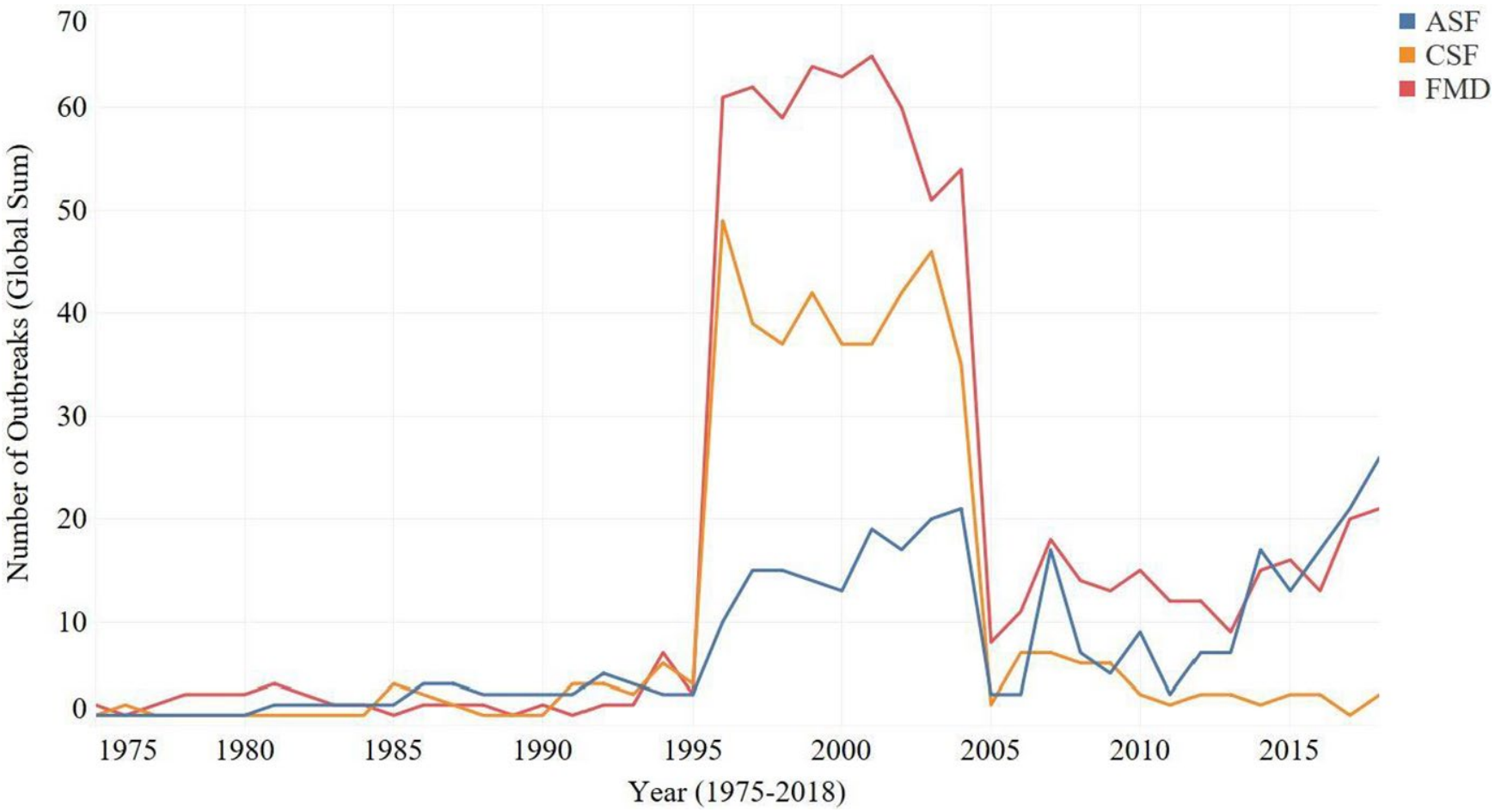

FIGURE 1 Number of ASF, CSF and FMD outbreaks worldwide, by year (OIE, 2019) [Colour figure can be viewed at wileyonlinelibrary. com] 
of Eastern Europe and neighbouring countries. The presence of the virus in Africa is unknown (Blome et al., 2017).

Foot-and-mouth disease, caused by foot-and-mouth disease virus (FMDV), is a highly contagious virus that infects cloven-hoofed animals, including cattle, buffaloes, sheep, goats, pigs and various wildlife species (FAO, 2012; Grubman \& Baxt, 2004). This virus can be spread both horizontally and vertically and causes low mortality but high morbidity. These disease dynamics contribute to the significant costs associated with an outbreak as affected animals have reduced growth rates and decreased milk production resulting from vesicles that develop in and around the oral cavity and along the hooves (Alexandersen et al., 2003). Foot-and-mouth disease is endemic in large areas of Asia and Africa, and South America had its most recent outbreak in Colombia in 2017. Based on strict trade measures, North America, Europe and Australia have been able to maintain an FMDV-free status in recent years without vaccination (Niedbalski et al., 2019).

Transboundary animal diseases are challenging to manage as the demand for animal protein increases, globalization of international trade increases, and climate change continually threatens ecosystems and agricultural production systems. Given the considerable impact of these three diseases, they have been the focus of a significant number of studies evaluating risks which have sought to provide guidance it mitigate risk, conduct contingency planning and insights to potential economic outcomes (e.g. Boklund et al., 2013; Halasa, Boklund, et al., 2016; Halasa, Bøtner, et al., 2016). The majority of this work has likely resulted from World Organisation for Animal Health (OIE) requirements to conduct risk and economic consequence assessments, resulting in most available assessments being narrowly focused to specific geographic region(s) and often addressing OIE guidelines. Despite the significant amount of work available for ASF, CSF and FMD, there remains a paucity of work to synthesize the literature and identify gaps and needs.

Knowledge about the economic consequences of ASF, CSF and FMD can better inform effective allocation of resources for disease prevention and potential response. Economic analyses have been carried out in regions around the world since at least the late 1970s; however, there has yet to be a rigorous meta-analysis or review of either the economic literature for ASF, CSF and FMD individually or collectively in more than 10 years. KnightJones and Rushton (2013) provide an extensive table of existing

TAB LE 1 Risk evaluation \& economic scoping review, PRISMA steps

\begin{tabular}{|c|c|c|c|c|c|}
\hline \multirow[b]{2}{*}{ PRISMA step } & \multirow[b]{2}{*}{ Text evaluated } & \multicolumn{2}{|l|}{ Search terms } & \multicolumn{2}{|l|}{ Exclusion criteria } \\
\hline & & Risk & Economic & Risk & Economic \\
\hline Identification & $\begin{array}{l}\text { Primary search } \\
\text { terms in title, } \\
\text { abstract, index } \\
\text { terms }\end{array}$ & $\begin{array}{l}\text { [Disease } \\
\text { name] + risk + assessment } \\
\text { OR analysis OR pathway }\end{array}$ & $\begin{array}{l}\text { [Disease name] + economic } \\
\text { [Disease name] + 'economic } \\
\text { damage' } \\
\text { economic } \\
\text { loss } \\
\text { cost }\end{array}$ & $\begin{array}{l}\text { Studies without } \\
\text { Identification } \\
\text { primary search } \\
\text { terms in title, } \\
\text { abstract or index } \\
\text { terms }\end{array}$ & $\begin{array}{l}\text { Studies without } \\
\text { Identification } \\
\text { primary search } \\
\text { terms in title, } \\
\text { abstract or index } \\
\text { terms }\end{array}$ \\
\hline Screening & NA & NA & NA & $\begin{array}{l}\text { Not published in } \\
\text { peer-reviewed } \\
\text { journal or as } \\
\text { government } \\
\text { technical report } \\
\text { Unable to locate } \\
\text { Not in English } \\
\text { Does not pertain } \\
\text { to (disease OR } \\
\text { Risk analysis) }\end{array}$ & $\begin{array}{l}\text { Not published in } \\
\text { peer-reviewed } \\
\text { journal } \\
\text { Unable to locate } \\
\text { Not in English } \\
\text { Does not pertain } \\
\text { to (disease OR } \\
\text { economic analysis) }\end{array}$ \\
\hline Eligibility & $\begin{array}{l}\text { Secondary search } \\
\text { terms in full text }\end{array}$ & $\begin{array}{l}\text { Risk } \\
\text { Pathway } \\
\text { Assessment } \\
\text { Analysis }\end{array}$ & $\begin{array}{l}\text { Economic } \\
\text { Cost } \\
\text { Loss } \\
\text { Dollar } \\
\text { Total } \\
\text { 'Total economic' }\end{array}$ & $\begin{array}{l}\text { Do not present } \\
\text { own results }\end{array}$ & $\begin{array}{l}\text { Do not present own } \\
\text { results } \\
\text { No outbreak cost/ } \\
\text { loss analysis }\end{array}$ \\
\hline Included & Full text & NA & NA & $\begin{array}{l}\text { Not published in } \\
\text { peer-reviewed } \\
\text { journal or as } \\
\text { government } \\
\text { technical report } \\
\text { Unable to locate }\end{array}$ & $\begin{array}{l}\text { Not published in } \\
\text { peer-reviewed } \\
\text { journal } \\
\text { Unable to locate } \\
\text { No outbreak cost/ } \\
\text { loss analysis } \\
\text { No historic } \\
\text { exchange rate } \\
\text { available for time } \\
\text { of study }\end{array}$ \\
\hline
\end{tabular}


cost-benefit analysis studies of FMD control and eradication programs as a part of their original economic analysis (Knight-Jones \& Rushton, 2013). However, the paper does not specifically function as a scoping or systematic literature review. Bennett and IJpelaar (2005) also carried out a review of 34 endemic diseases to Great Britain where they outlined new developments in economic analysis and updated disease cost estimates; however, they did not report a table of all findings and briefly summarize results with no mention of FMD (Bennett \& IJpelaar, 2005). While acknowledging that many economic evaluations of non-zoonotic animal disease programs have been carried out on an ad hoc basis, Perry \& Grace (2009) conclude that the varying diseases, methodologies and results make it difficult to draw general conclusions or compare diseases (Perry \& Grace, 2009). It should also be noted that most of these studies have been carried out in developed countries and those from developing counties rarely consider the differential impact on the poor (Perry \& Grace, 2009).

The objective of our study is twofold. First, to identify and illustrate potential risks (epidemiological or economic) posed by ASF, CSF and FMD. Second, to identify knowledge gaps and opportunities to better inform policy, risk management and applied research. To accomplish this, we used two separate scoping reviews. We first present the methods and results of these two scoping reviews. We then discuss the risks and economic implications of each of these diseases based on the findings of both reviews. Finally, we conclude by illuminating the most important takeaways from this analysis, and consider the roles invasive feral swine may play in transmission dynamics of these diseases in the United States in the event of an outbreak. We originally anticipated this to be a U.S. focused review; however, the paucity of available data forced us to expand our efforts to a global scale.

\section{2 | METHODS}

We used systematic scoping reviews as our primary tool given the large, heterogeneous nature of comparing epidemiological and economic literature. These reviews were based on the methodological guidance outlined by Peters et al. (2015) and utilized the PRISMA methods (Preferred Reporting Items of Systematic Reviews and Meta-Analyses; Moher et al., 2009, 2015) for systematic scoping reviews. Specific text evaluated, search terms and exclusion criteria, based on each PRISMA step, are outlined for the risk evaluation and economic literature reviews (respectively) in Table 1.

\section{1 | Scoping review 1: risk evaluation}

In the risk evaluation scoping review, we examined the range of studies evaluating risk that have been conducted for ASF, CSF and FMD globally. Risk assessment is a broad area of analysis that can represent quantitative or qualitative analyses and can be limited to just the pathway of introduction or include an analysis of the mechanisms which drive disease spread. Within the OIE framework, risk assessment is a rigorous structured approach that conducts

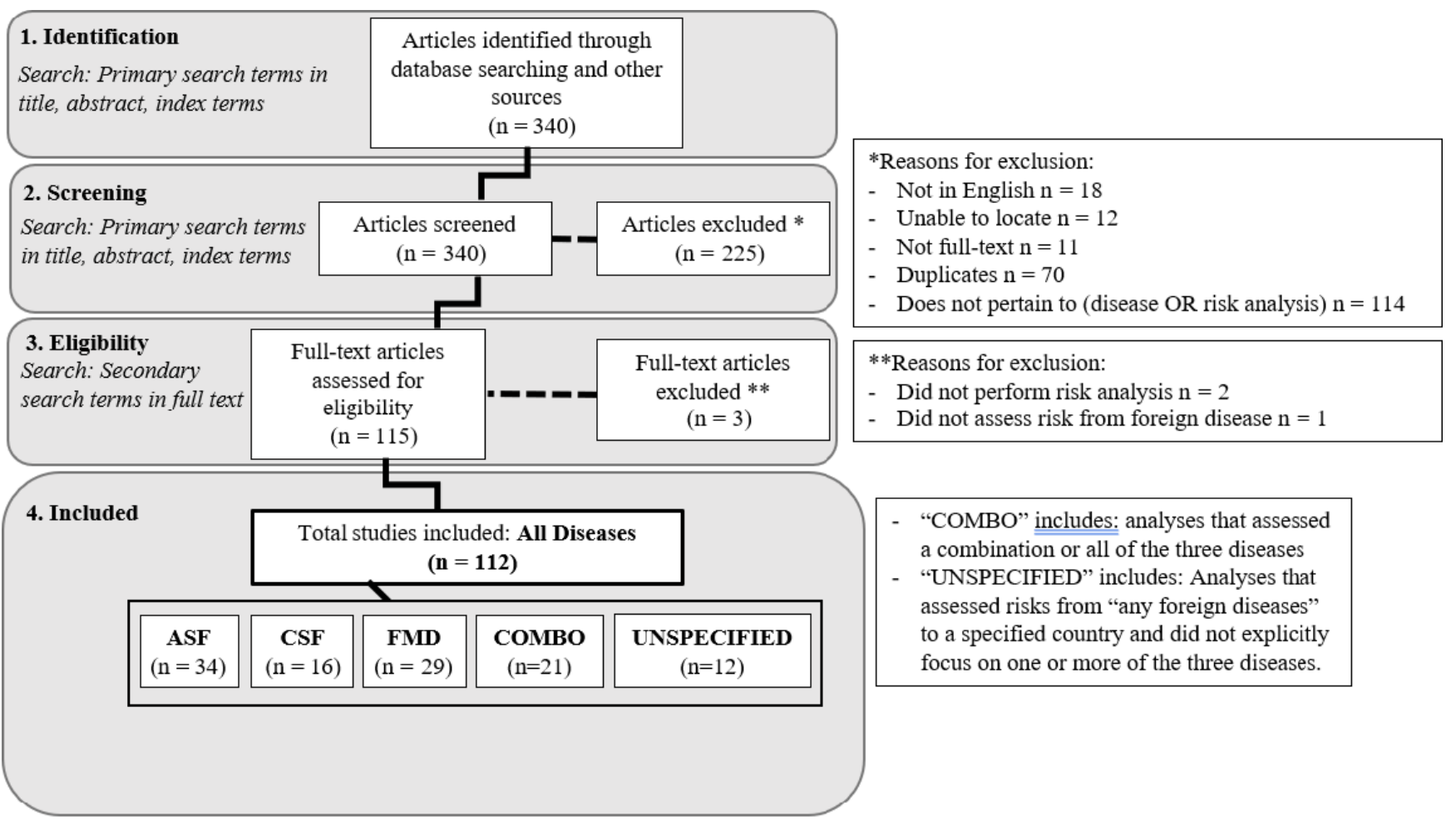

FIGURE 2 Risk evaluation scoping literature review, PRISMA outcomes [Colour figure can be viewed at wileyonlinelibrary.com] 


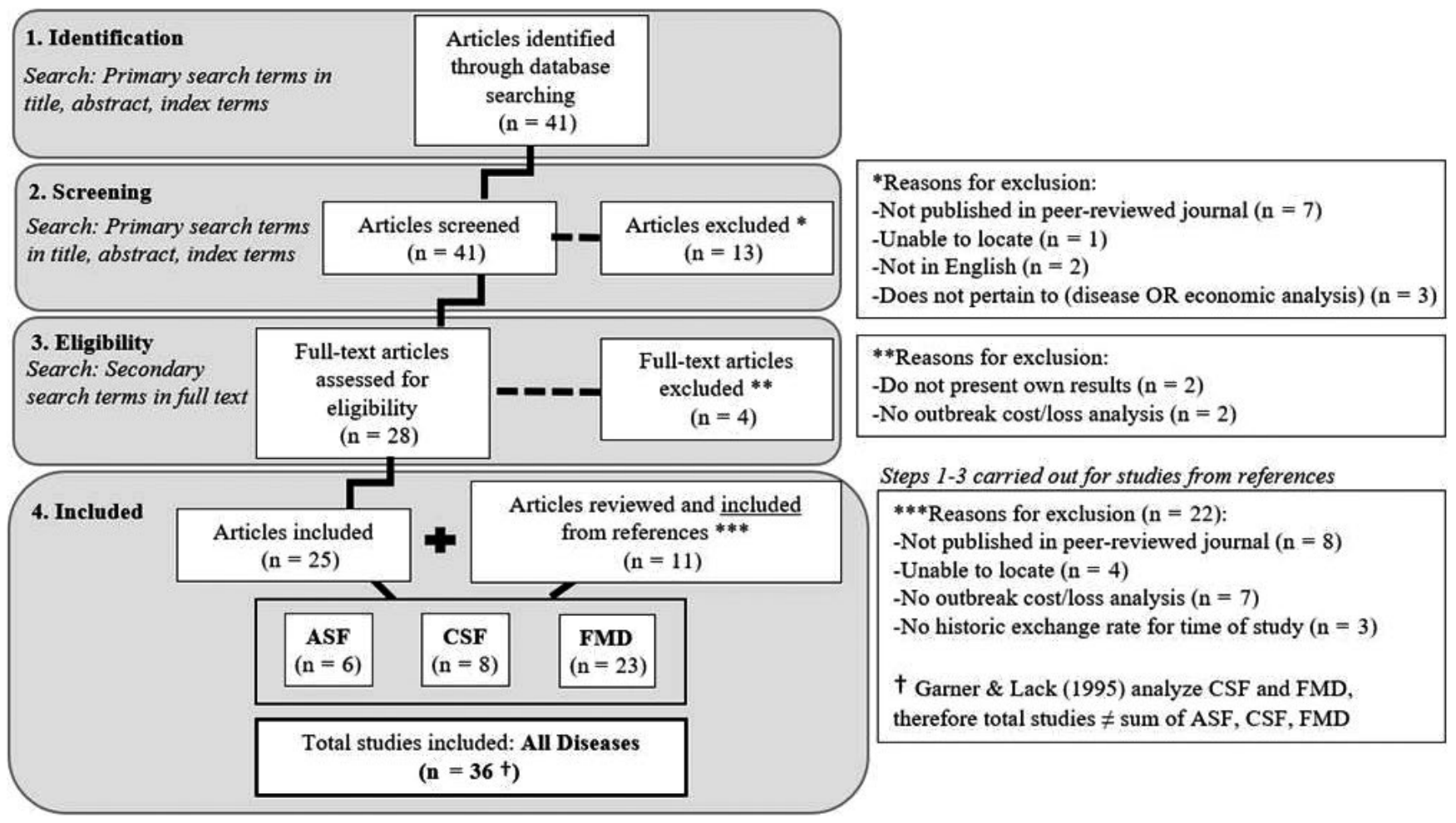

FIGURE 3 Economics scoping literature review, PRISMA outcomes

specific assessments-release assessment, exposure assessment, probability of occurrence-which are used with a consequence assessment to arrive at a final risk estimation (Dufour et al., 2011). To capture the breadth of studies investigating potential risks associated with these pathogens, all literature evaluating risks were considered eligible and are reflected in the use of broad search terms. We did not limit our search to only studies using OIE risk assessment framework as many studies address only a few aspects of the framework. All scientific peer-reviewed literature from journals, edited book volumes, government reports, technical documents or other similar documents were considered eligible, as well as grey literature consisting of mainly unpublished government reports. To identify studies, we used keywords to search four databases (PubMed, Scopus, Web of Science and National Agricultural Library). Studies in English published in any year through 2019 were considered eligible. Once all relevant sources were identified and retrieved, we reviewed each source to ensure relevance and data were extracted. A detailed description of these are included in Appendix Table A1, but in summary, included information pertained to pathogen type, risk evaluation type, pathways of introduction, geographic source (where the virus could come from) and destination (where the virus could end up), models used in the risk evaluation and other pertinent information. Additionally, the associated highest risk variables (i.e. introduction pathway, geographic source and destination, and consequence) were recorded in the database if they were identified by the study evaluating risk. This process is outlined in Figure 2, and a total of 112 literature sources were included in the database.

\subsection{Scoping review 2: economic impact}

In the economic impact scoping review, we identified where ASF, CSF and FMD studies have been carried out, compare economic outcomes and identify research gaps. Studies were classified by the pathogen type and sorted by continent and country. Literature included was found through Google Scholar and the PRIMO (PeerReviewed Instructional Materials Online) database. Peer-reviewed literature published any year through 2019, in English, was included. Methodological quality was not assessed in this review as it is not a specific criterion for scoping reviews [29]; however, inclusion of only peer-reviewed literature should imply methodological soundness. Grey literature was not considered in this case, and articles were not retained if they only reported results from another source (results were then sought out in their original documentation). A total of 35 sources were reviewed for the economic literature (Figure 3 ).

\section{3 | RESULTS}

\section{1 | Scoping review 1: risk evaluation}

\subsection{1 | Geographic location}

Thirty-two (28.6\%) of the reviewed documents assessed the risks posed to the United States, and the remaining 80 (71.4\%) assessed risks associated with other foreign countries. The overwhelming majority of the foreign risk evaluations $(51(63.7 \%))$ identified risk to 
TAB LE 2 Descriptive summary of the United States and foreign studies evaluating risk characterized by pathogen(s) evaluated and the type of risk evaluation

\begin{tabular}{|c|c|c|c|c|c|c|c|c|}
\hline & \multicolumn{4}{|c|}{ Pathogen evaluated } & \multicolumn{4}{|c|}{ Type of assessment } \\
\hline & ASFV & CSFV & FMDV & Combination & Qualitative & $\begin{array}{l}\text { Semi- } \\
\text { quantitative }\end{array}$ & Quantitative & Both \\
\hline U.S. assessments & 3 & 9 & 10 & 8 & 16 & 1 & 6 & 8 \\
\hline Foreign assessments & 32 & 7 & 19 & 13 & 39 & 10 & 22 & 9 \\
\hline
\end{tabular}

${ }^{a}$ One U.S. assessment and 11 foreign assessments did not identify pathogen evaluated.

European countries and regions, and 8 (10.0\%) of the foreign risk evaluations did not identify a specific geographic destination but still evaluated possible routes of introduction, and so were considered relevant to our study and included. As for the remaining foreign risk evaluations, 7 (8.7\%) assessed risk to countries in Asia, 6 (7.5\%) assessed New Zealand, 3 (3.7\%) assessed African countries, 2 (2.5\%) assessed Canada, 2 (2.5\%) assessed Brazil, and 1 (1.2\%) assessed the risk to Australia.

\subsection{2 | U.S. risk evaluation: highest risk geographic source and destination}

Of the 32 documents evaluating risk to the United States, only $6(18.7 \%)$ identified specific countries as being the most likely source of an outbreak. The geographic locations identified were Asia, Canada, Cuba, the Dominican Republic, Germany, Italy, Russia and the United Kingdom. Ten studies evaluating risk (31.2\%) identified risks below the national scale, identifying specific locations within the United States as the highest risk for virus introduction. These locations were California, Florida, lowa, Minnesota, Puerto Rico, Texas, Wisconsin and the southwest region of the U.S, as well as the major airports of Florida, New Jersey, New York, North Carolina, Ohio, Puerto Rico, Rhode Island, Texas and Virginia. Risk factors common among these states included (a) dense livestock populations, (b) large international airports, (c) existing feral swine populations and (d) presence of swine waste feeding operations.

\subsection{3 | Pathogens evaluated}

Thirty-three (29.5\%) of the 112 total studies evaluating risk specifically assessed ASF, 17 (15.2\%) assessed CSF, and 29 (25.9\%) assessed FMD. Another 21 (18.7\%) assessed a combination of two or more diseases, and 12 (10.7\%) risk evaluations did not identify a specific disease and so are not included in 'Pathogen Evaluated' section of Table 1. However, these studies evaluating risk were considered relevant as they still evaluated potential pathways of introduction to a country for 'any foreign disease', which while not specifically stated, is assumed to include ASF, CSF and FMD.

\subsection{4 | Risk evaluation types and models used}

Of the 112 assessments, there were 55 (49.1\%) qualitative reviews, 28 (25.0\%) quantitative, 11 (9.8\%) semi-quantitative analyses, and 18 (16.1\%) performed a combination of both qualitative and quantitative analyses. A variety of models were used within the literature, including, but not limited to: net trade, stochastic, multi-level binomial, logistic and linear regression, Monte Carlo simulations, Hierarchal cluster analyses and Scenario trees. Table 2 itemizes the pathogen(s) evaluated and the types of assessments utilized.

\subsection{5 | Assessed pathways of introduction}

The majority of the studies evaluating risk considered many pathways for pathogens to be introduced to a specific country or continent. The primary pathways of disease introduction assessed by all 112 studies included the following: natural movement of wildlife; legal and illegal imports of animals and animal products including bushmeat and genetic material; by way of commercial, personal, or military planes, ships, vehicles and mail; and bioterrorism. Many risk evaluations then determined which of the assessed pathways of disease introduction could be the highest risk to the country or region being evaluated.

\subsection{6 | Foreign assessments: highest risk pathway of introduction}

Across all three diseases, 34 (42.5\%) of the foreign assessments did not identify a highest risk pathway of introduction, but of the 46 that did, the majority (32 (69.6\%)) identified legal and illegal importations of live animals, meat and meat products, animal feed, genetic material and bioterrorism to be the pathways of highest risk. Another 8 (17.4\%) identified cross-border movements of livestock or wild boar, 6 (13.0\%) identified swill-feeding, 6 (13.0\%) identified cross-border movements of livestock trucks, and 2 (4.3\%) identified other fomites such as shoes, clothing, supplies and fresh-cut grass from infected areas. It is important to note that some assessments reported multiple pathways of introduction as highest risk. 
The only pathway of introduction that varied based on disease within the foreign assessments was returning livestock vehicles and other fomites. This pathway was identified as highest risk primarily by European assessments evaluating the risk posed by ASF. Only two assessments, also European, identified returning livestock trucks specifically as highest risk for CSF, and none of the foreign assessments evaluating FMD reported any fomites as a highest risk pathway of introduction.

\subsubsection{U.S. assessments: highest risk pathway of introduction}

Of the 32 U.S. assessments, 17 (53.1\%) did not identify a pathway of introduction of highest risk, but 11 assessments (34.4\%) identified legal or illegal imports (including bioterrorism) of animals, animal products, animal feed or genetic material, as the highest risk pathway of introduction, most commonly by way of air passenger or air passenger baggage. In addition, 2 U.S. assessments (6.2\%) identified swill-feeding as being the highest risk pathway of introduction, 1 (3.1\%) identified the importation of diagnostic samples, and 1 (3.1\%) identified Ornithodoros ticks, as they can be vectors for ASF. Importantly, these ticks were identified to be the highest risk in comparison with all other tick species that can transmit the disease; however, ticks as vectors were not identified as a highest risk pathway of introduction to the United States when compared to all other possible routes of introduction. Unlike the foreign assessments, none of the U.S. assessments identified wild boar or their movements as a highest risk pathway of introduction.

\section{2 | Scoping review 2: economic impact}

A total of 36 peer-reviewed articles were found, in English, which presented their own economic analysis. One article by Garner and Lack (1995) addressed both a study on CSF and another on FMD. Broken down, we identified six studies for ASF (16.2\% of all 37 disease studies), eight for CSF (21.6\%), and 23 for FMD (62.2\%) (Figure 3) for a total of 37 studies within 36 articles. Eight institutional or government reports were reviewed and not included in the selection because they were not published through the peer-review process. The economic evaluations carried out among the studies included the following: Agricultural sector model (ASM), benefit-cost analysis (BCA), computable general equilibrium (CGE), economic impact assessment (EIA), input-output (I/O), partial equilibrium (PE), partial budget model (PBM), referred to as 'financial costing' (FC) where a more accounting-type approach is taken to quantify economic impacts. Across all studies, a total economic cost or loss (or combination of the two) was estimated, often pertaining to agricultural production loss and epidemic control costs. Costs were often associated as government costs, and loss was most often reported as production loss to the livestock or milk industries. To our knowledge, no studies specifically addressed feral swine as the primary source of disease introduction but several studies suggested with may contribute to establishment and spread if the disease was introduced.

The range of costs and/or losses presented for ASF was from $\$ 649,000$ to $\$ 94,539,870,064$ (USD, 2019) which represent the average annual pig production loss from an outbreak in Nigeria (Fasina et al., 2012) and the total economic loss value of swine depopulated from an outbreak in Spain (Bech-Nielsen et al., 1993), respectively. The range of costs and/or losses presented for CSF was from $\$ 58,338$ to $\$ 585,762,061$ (USD, 2019) which represent the total direct annual production loss from an outbreak in Australia (Garner et al., 2001) and the maximum median epidemic cost (based on infected herd) of an outbreak in Denmark (Boklund et al., 2009), respectively. Finally, the range of costs and/or losses presented for FMD was between $\$ 83$ and $\$ 84,584,000,000$ (USD, 2019) which represent total average economic loss per herd from an outbreak in Ethiopia (Jemberu et al., 2014) and the maximum, median total national loss in agricultural surplus from an outbreak in California in the United States (Carpenter et al., 2011), respectively. These ranges highlight the fact that geospatial information and scale are paramount to compare studies and since that was not uniform, it is nearly impossible to make generalizations about which of these diseases is the most costly.

The economic scoping review affirmed that an outbreak of any of these diseases is expensive and that the economic impact of each disease is driven by a number of factors, including location of outbreak (e.g. Hop et al., 2016; Mahul \& Durand, 2000; Pendell et al., 2007), trade implications (e.g. Babalobi et al., 2007; Countryman \& Hagerman, 2017; Mangen et al., 2004) and consumer reaction (e.g. Blake et al., 2003; Thompson et al., 2002). The results of the review also implied that disease management and control practices heavily contribute to the economic impact of the disease (e.g. Boklund et al., 2009; Schoenbaum \& Disney, 2003). Comparing across studies, analyses were often partial in terms of total impact evaluation (micro and macroeconomic), therefore not capturing the full burden on the economy.

Of the 37 studies, a total of nine peer-reviewed published studies were 'retrospective' studies (25.7\%) and the remaining 26 studies

\begin{tabular}{|c|c|c|}
\hline Study type & Description & \# Studies \\
\hline Retrospective & $\begin{array}{l}\text { Ex-post analysis of historical outbreak. Provides an } \\
\text { economic impact value based on observed outcomes of } \\
\text { the outbreak }\end{array}$ & 9 \\
\hline Forecast & $\begin{array}{l}\text { Hypothetical outbreak scenario. Purpose is economic } \\
\text { impact evaluation for future outbreak potential }\end{array}$ & 26 \\
\hline
\end{tabular}

TABLE 3 Count of studies included in literature review, by study type 
TAB LE 4 Count of countries with economic analyses, by disease, by 'Retrospective' (Retro.) or 'Forecast' (For.)

\begin{tabular}{|c|c|c|c|c|c|c|c|c|c|}
\hline $\begin{array}{l}\text { Country } \\
\text { name }\end{array}$ & $\begin{array}{l}\text { FMD } \\
\text { Retro. }\end{array}$ & FMD For. & ASF Retro. & ASF For. & CSF Retro. & CSF For. & $\begin{array}{l}\text { Total } \\
\text { Retro. }\end{array}$ & Total For. & $\begin{array}{l}\text { Total } \\
\text { analyses }^{\text {a }}\end{array}$ \\
\hline Argentina & 1 & 0 & 0 & 0 & 0 & 0 & 1 & 0 & 1 \\
\hline Belgium & 0 & 0 & 0 & 0 & 0 & 1 & 0 & 1 & 1 \\
\hline Brazil & 1 & 0 & 0 & 0 & 0 & 0 & 1 & 0 & 1 \\
\hline Ecuador & 1 & 0 & 0 & 0 & 0 & 0 & 1 & 0 & 1 \\
\hline Ethiopia & 1 & 0 & 0 & 0 & 0 & 0 & 1 & 0 & 1 \\
\hline France & 0 & 1 & 0 & 0 & 0 & 0 & 0 & 1 & 1 \\
\hline Germany & 0 & 0 & 0 & 0 & 0 & 1 & 0 & 1 & 1 \\
\hline Spain & 0 & 0 & 0 & 1 & 0 & 0 & 0 & 1 & 1 \\
\hline S. Sudan & 1 & 0 & 0 & 0 & 0 & 0 & 1 & 0 & 1 \\
\hline Taiwan & 1 & 0 & 0 & 0 & 0 & 0 & 1 & 0 & 1 \\
\hline Turkey & 1 & 0 & 0 & 0 & 0 & 0 & 1 & 0 & 1 \\
\hline UK & 1 & 1 & 0 & 0 & 0 & 0 & 1 & 1 & 2 \\
\hline USA & 0 & 9 & 0 & 1 & 0 & 0 & 0 & 10 & 10 \\
\hline Uruguay & 1 & 0 & 0 & 0 & 0 & 0 & 1 & 0 & 1 \\
\hline Venezuela & 1 & 0 & 0 & 0 & 0 & 0 & 1 & 0 & 1 \\
\hline
\end{tabular}

${ }^{a}$ Totals presented here are not counts of individual studies-they are counts of economic analyses by country.

were categorized as 'forecast' (74.3\%; Table 3). We define 'retrospective' as an ex-post analysis of an actual historic outbreak with the purpose of providing an economic impact value based solely on observed outcomes of the outbreak. A retrospective study utilizes data specifically from one historic outbreak (or outbreak period) to determine the economic impact. We define 'forecast' as a study whereby a hypothetical outbreak scenario is created with the purpose of economic impact evaluation. Forecast studies often utilize simulation models based on historic outbreak data to provide insight into the potential economic impacts of varying outbreak sizes and control strategies. Forecast studies often aim to inform future epidemic outbreak management decisions. All studies which used simulation modelling were labelled as 'forecast', but not all forecast studies used simulation modelling.

\subsection{1 | Geographic span of analyses}

Collectively, economic analysis was carried out in six of the seven global continents. Table 4 lists the 21 countries represented in economic studies and totals the number of analyses carried out by disease and analysis type (retrospective or forecast). Analyses tended to focus on country-wide economic effects of disease outbreaks in one respective country. However, two transcontinental/global FMD studies were also carried out, one being an analysis in Turkey by Senturk and Yalcin (2008) which spans both Asia and Europe and the other from Knight-Jones and Rushton (2013) which is a global economic impact analysis of FMD in countries/regions in Asia, Africa, Europe and South America. Two studies for CSF were multicountry studies, one between the Netherlands and Germany (Hop et al., 2016) and the other between the Netherlands and Belgium (Saatkamp et al., 2000). For FMD in the United States, Carpenter et al. (2011), Pendell et al. (2007) and Bates et al. (2003), respectively, consider outbreaks in the state of California, the state of Kansas (and regions within) and a three-county region in California.

To explore the relationships between the prevalence of peer-reviewed research and outbreak location, we created four bivariate chloropleth world maps (Figures 4, 5, 6 and 7). Figure 4 demonstrates the relationship between the number of outbreaks of ASF, CSF and FMD (1975-2018) and the number of retrospective (ex-post) economic studies. To follow, we considered the relationship between livestock or swine per capita and the number of forecast economic studies in Figures 5, 6 and 7 for FMD, ASF and CSF, respectively. The number of livestock or swine per capita is a proxy for the weight carried by livestock or swine (thus at risk for FMD, ASF or CSF) in a country's economy.

Figure 4 shows the number of outbreaks of ASF, CSF and FMD (1975-2018) on the $x$-axis, and on the $y$-axis the number of 


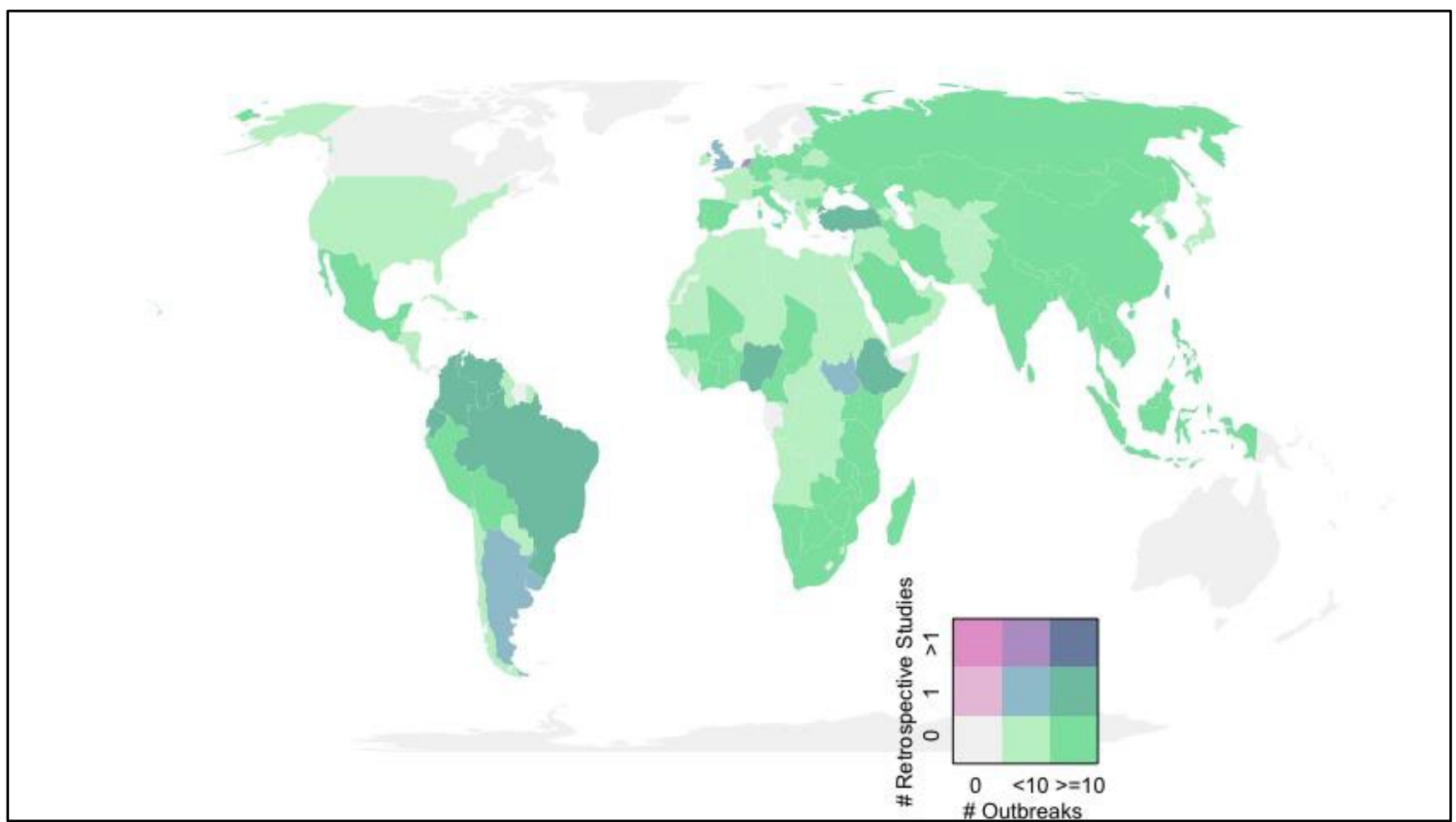

FIGURE 4 Number of outbreaks of ASF, CSF and/or FMD between 1975 and 2018 and number of retrospective economic studies. (1) Data for $x$-axis are publicly available from the World Organisation for Animal Health (OIE) website (OIE, 2020) presented in Table A2 in the Appendix. Range of years was based on year of publication for studies included in the literature review, and availability of OIE data. (2) The 177 countries on the $x$-axis are arbitrarily divided into three groups (terciles) based on the number of ASF, CSF and FMD outbreaks reported 1975-2018. Group 1X (group 1 on far left, $x$-axis) countries reported no outbreaks. Group 2X reported 1-9 respective disease outbreaks. Group 3X experienced 10 outbreaks or more. (3) The $y$-axis is grouped by number of peer-reviewed retrospective studies by country. Group 1Y (group 1 on bottom, y-axis) includes countries with zero retrospective studies, Group $2 Y$ with 1 retrospective study, and Group 3Y included with more than one retrospective study. (4) Group 1X (no outbreaks): 31 countries (shaded in light grey) (18\% of all reported countries)-incl. Australia, Canada, Norway, South Africa and Sweden. (5) Group 2X (1 to 9 outbreaks): 78 countries (44\% of all reported countries) -72 countries did not maintain any retrospective economic analyses including: the United States, over 15 European countries, Chile and Japan (shaded in light green)-Five countries reported 1 (Argentina, South Sudan, Taiwan, the United Kingdom and Uruguay) (shaded in blue)-Only the Netherlands published more than one study (shaded in light purple). (6) Group 3X (10 outbreaks or more): 68 countries (38\% of all reported countries). 61 including China, Italy, Russia and Spain (shaded in bright green) did not have ex-post economic analysis [90\% of Group 3X]. Seven countries-Brazil, Columbia, Ecuador, Ethiopia, Nigeria, Turkey and Venezuela (shaded in dark green) conducted only one analysis. No country in Group 3X performed more than one economic analysis [Colour figure can be viewed at wileyonlinelibrary.com]

retrospective economic studies. The mean number of outbreaks across all countries was 7.8 , and the median was 6 . Overall, the results in Figure 4 suggest that despite the important number of outbreaks reported 1975-2018 (1,547 outbreaks of ASF, CSF and FMD, collectively), few (11) retrospective economic studies have been published. The results also suggest that there is no correlation between the frequency of disease outbreaks and number of ex-post, retrospective economic studies published. In particular, the top five countries with the most total reported outbreaks (ASF, CSF, FMD combined) were Russia (49), China (45), Italy (43), South Africa (32) and Zambia (29). Based on this literature review, there are no published economic (retrospective or forecast) studies for these leading five countries for total outbreaks.

Figure 5 represents the relationship between hooved livestock (cattle, goats, sheep and pigs) per capita in 2018 on the $x$-axis (in terciles), and the number of forecast economic studies published for
FMD on the $y$-axis, for 175 countries for which data were available. The number of livestock per capita is a proxy for the weight carried by livestock (thus at risk for FMD) in a country's economy. In the first tercile (less than 0.23 livestock per capita), none of the 58 countries had any forecast studies. In the second tercile (more than 0.23 and up to 0.56 livestock per capita), only the United Kingdom (shaded in blue) conducted one simulation, and the United States (shaded in light purple) conducted nine studies. The remaining 56 countries in that tercile did not conduct any forecast study. Among the third tercile (59 countries, more than 0.56 animals per capita), where the number of livestock per capita is the highest, 54 countries (91.5\% of tercile 3)-including Argentina, Canada and Spain-did not conduct any anticipatory economic analysis despite the high potential impact to their economy given the high livestock density per capita. These countries are shaded in bright green. Four countries, Australia, France, the Netherlands and New Zealand (shaded in dark 


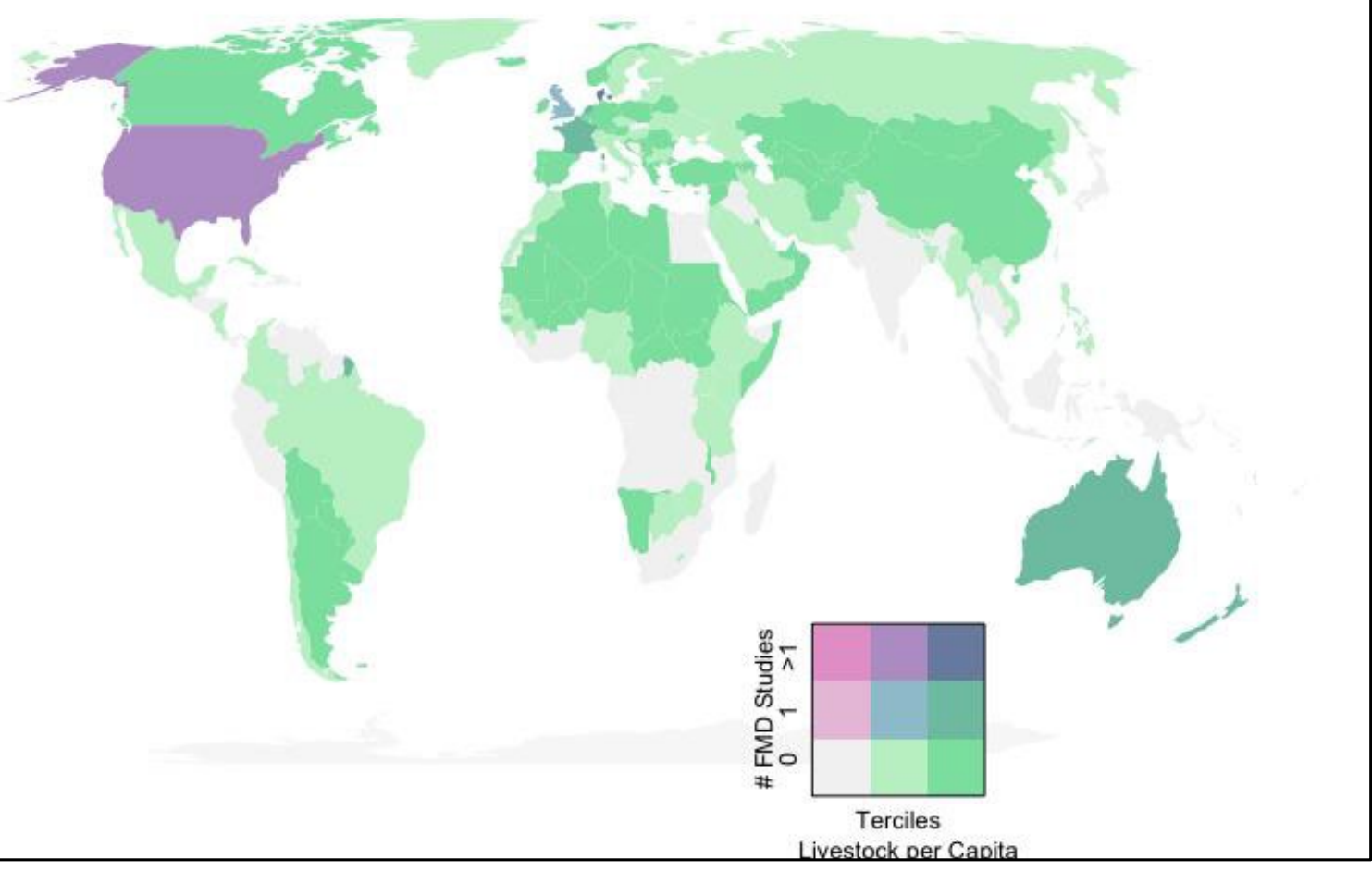

FIGURE 5 Number of head of livestock per capita (in terciles) and number of forecast economic studies for FMD. (1) For the $x$-axis, number of hooved livestock by country is based on publicly available data from the Food and Agriculture Organization of the United Nations (FAO). Livestock production data for 'Livestock Primary' animals (definitions and methodology can be found through the source link provided; FAO, 2019c). Human population by country data was retrieved from the United Nations Department of Economic and Social Affairs Population Dynamics data (United Nations, 2020). These numbers can be found in Table A2 in the Appendix. (2) On the $x$-axis, countries were divided into three groups (terciles) of 58 or 59 countries each based on the number of livestock per capita listed for each country in 2018. Group $1 X$ (group 1, far left on $x$-axis) is livestock per capita less than 0.23 . Group $2 X$ represents between 0.23 and 0.56 livestock per capita, and the third represents more than 0.56 animals per capita. Group $3 X$ represents countries with more than 0.56 animals per capita. (3) The $y$-axis is grouped by number of peer-reviewed forecast economic studies for FMD by country. Group $1 Y$ (group 1, bottom of $y$-axis) includes countries with zero studies, Group $2 Y$ had 1 retrospective study, and Group $3 Y$ included more than one forecast study. (4) Group 1X, 1Y countries did not publish any forecast studies for FMD (shaded in grey). (5) Among the 58 2X countries, 56 (including Brazil, Chile, Italy and Russia) did not conducted any simulated economic study (shaded in light green). The United Kingdom (shaded in blue) conducted one simulation, and the United States (shaded in purple) conducted 9 studies. (6) Among the 59 3X countries, 54 countries (shaded in bright green)-including Argentina, Canada and Spain-did not conduct any prospective economic analysis despite the high potential impact to their economy given the high livestock density per capita. Four countries, Australia, France, the Netherlands and New Zealand (shaded in dark green), conducted one forecast study, and only Denmark conducted two [Colour figure can be viewed at wileyonlinelibrary.com]

green), conducted one forecast study, and only Denmark conducted two (8.5\% of tercile 3 ). The results indicate no correlation between the potential impact on the economy of an FMD introduction and the number of forecasting analyses of the economic impact of the disease.

We carried out the same exercise for ASF and CSF, this time using terciles based on swine per capita in 2018 on the $x$-axis, and the number of forecast economic studies published for ASF (Figure 6) or CSF (Figure 7) in three terciles on the $y$-axis. The number of swine per capita is a proxy for the weight carried by swine production in a country's economy, which is at risk in the case of an ASF or CSF introduction. Overall, it was found that regarding ASF studies (Figure 6), no countries in tercile 1 (less than 0.01 swine per capita, 58 countries in light grey) conducted simulated studies, and among tercile 2 studies (between 0.01 and 0.14 swine per capita, also 58 countries), only Nigeria (blue) conducted a forecast study. The remaining 57 countries in tercile 2 (including Brazil, Chile, Italy and Russia) did not conduct any simulated economic studies and are shaded in light green. For tercile 3 (above 0.14 swine per capita), where the number of swine per capita is the highest (57 countries), 54 of those countries $(94.7 \%$, including Argentina, Australia, Canada, Russia and most of Europe) did not conduct any prospective economic analysis despite the potential impact to their economy. These countries are shaded in bright green. Three countries (5.3\% of tercile 3; Denmark, Spain and the United States), shaded in dark green, conducted one forecast study each, and no country conducted more than one forecast study overall. Again, the results indicate no correlation 


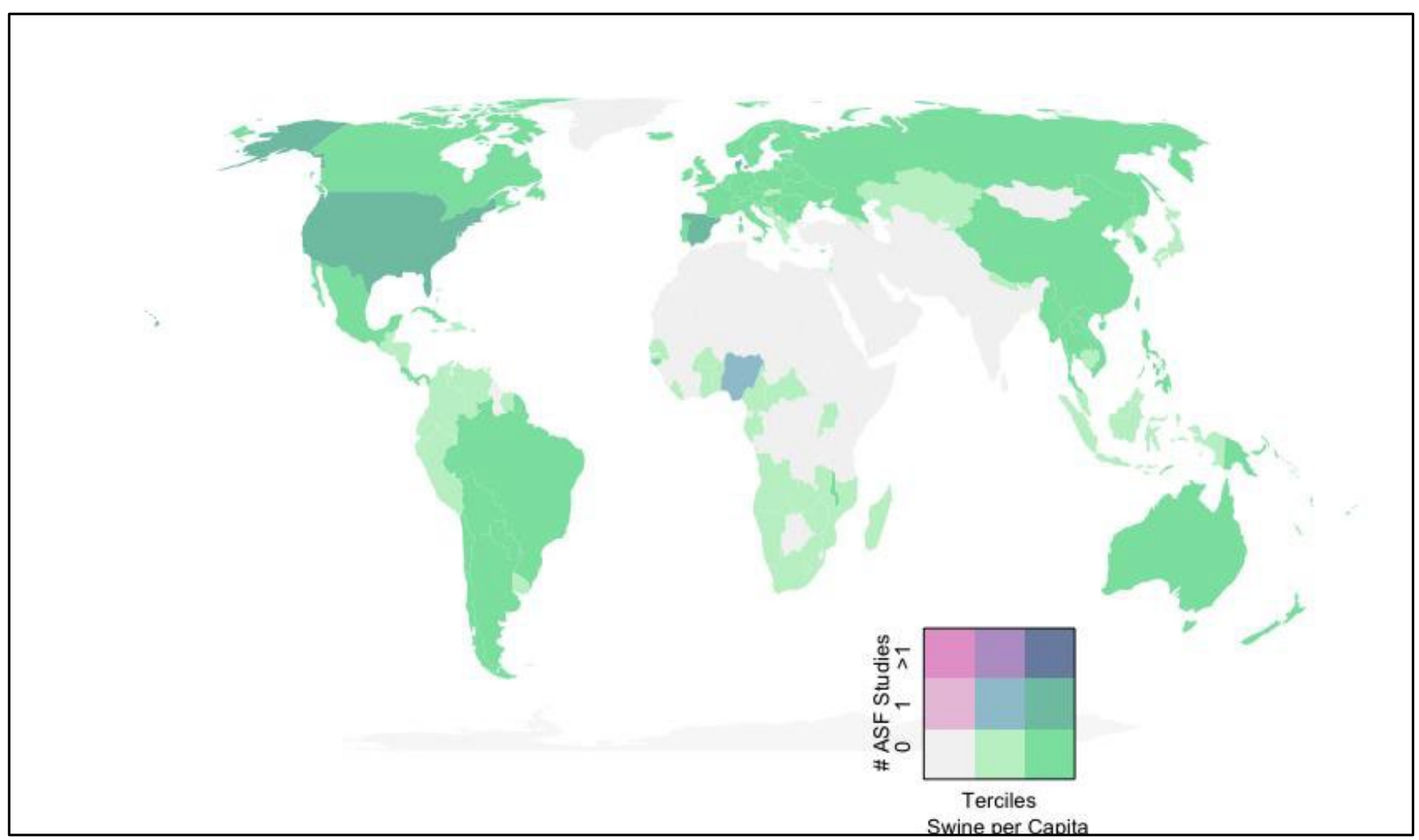

FIGURE 6 Head of livestock per capita (in terciles) and number of simulated economic studies for ASF. (1) For the $x$-axis, the number of swine per capita by country was based on the same publicly available data from the FAO, except only 'pigs' were selected from the 'Livestock Primary' animal data (FAO, 2019c). 171 countries had reported swine per capita data (1975-2018). The data used are presented in Table A5 in the Appendix. (2) On $x$-axis, countries were divided into 3 equally sized tercile groups based on the number of swine per capita where $1 \mathrm{X}$ (tercile 1 , far left on $\mathrm{X}$-axis) is less than 0.01 swine per capita, $2 \mathrm{X}$ is between 0.01 and 0.14 swine per capita and $3 \mathrm{X}$ is more than 0.14 swine per capita. (3) The $y$-axis is divided in to three groups by number of peer-reviewed forecast economic studies for ASF by country. Group $1 Y$ (tercile 1, bottom of $y$-axis) the $y$-axis includes countries with zero studies, Group $2 Y$ with 1 retrospective study, and Group $3 Y$ included with more than one forecast study. (4) In (1X,1Y) (tercile 1 for $x$ and $y$ axes) in light grey, no forecast studies of the economic impact of an introduction of ASF were conducted. (5) In tercile 2X, only one country, Nigeria (shaded in blue), conducted a forecast study of the economic impact of the introduction of ASF. The remaining 57 countries (including Brazil, Chile, Italy and Russia) did not conduct any simulated economic studies and are shaded in light green. (6) Among tercile 3X (57 countries), 54 (including Argentina, Australia, Canada, Russia and most of Europe) did not conduct any prospective economic analysis and are shaded in bright green. Three countries (Denmark, Spain and the United States), shaded in dark green, conducted one forecast study each, and no country conducted more than one forecast study overall [Colour figure can be viewed at wileyonlinelibrary.com]

between the potential impact on the economy of an ASF introduction and the number of forecasting analyses of the economic impact of the disease.

Finally, regarding swine per capita and CSF forecast studies (Figure 7), among the first and second tercile groups of swine per capita for CSF studies, no forecast studies of the economic impact of an introduction of CSF were conducted. These countries are shaded in light grey and light green, respectively. Fifty-seven countries were classified under tercile 3 , where the number of swine per capita is the highest. Of those countries, 52 (91.2\% of tercile 3, including Argentina, China, Russia and the United States) conducted no prospective economic analysis despite the potential impact to their economy. These countries are shaded in bright green. Belgium, Denmark and Germany (shaded in dark green) conducted one simulation, and Australia and the Netherlands (dark blue) both conducted two studies. This means that out of the
57 countries with the highest level of swine per capita, $8.8 \%$ have conducted forecast studies.

\subsubsection{Other economic review results}

Another finding from the economic review was the lack of consistency across studies in terms of the information describing data used in analyses. For example, definitions of economic terms were found to be decidedly variable (see column 'Economic estimation description' in Tables A2, A3 and A4 in the Appendix). To highlight the discrepancies regarding economic definitions, we compared WordCloud visuals (Jin, 2017) as a visual means to compare qualitative definitions of the quantitative studies. We used the definitions of 'total cost' or 'total loss' as provided by each paper (column nine 'Economic estimation description' in Tables A2, A3 


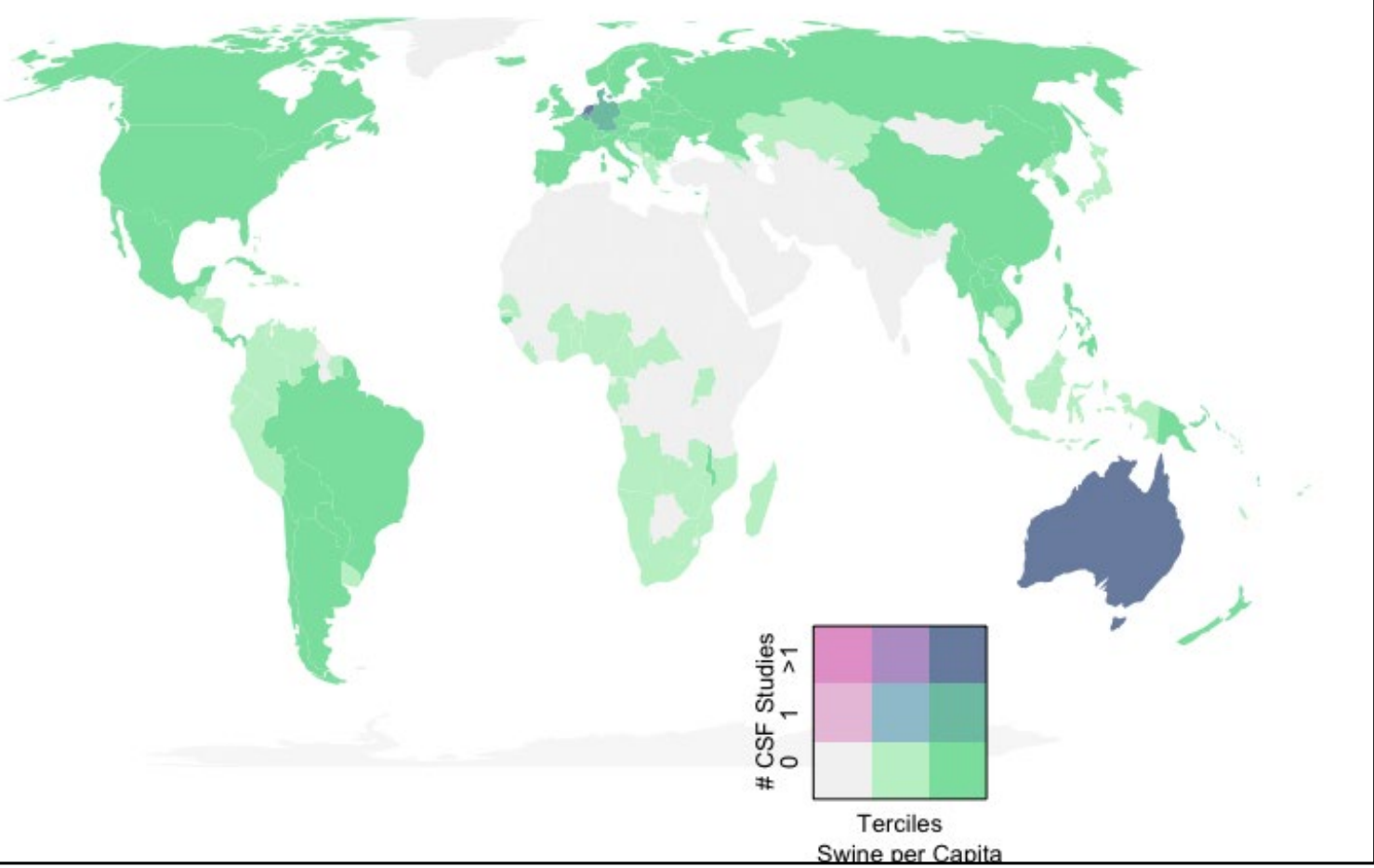

FIGURE 7 Number of head of livestock per capita (in terciles) and number of simulated economic studies for CSF. (1) The $x$-axis is the same as in Figure 6. (2) The $y$-axis is grouped by number of peer-reviewed forecast economic studies for CSF by country. Group $1 Y$ (tercile 1 , bottom of $y$-axis) includes countries with zero studies, Group $2 Y$ with 1 retrospective study, and Group $3 Y$ included with more than one forecast study. (3) For $1 X$ and $2 X$, no forecast studies of the economic impact of an introduction of CSF were conducted. These countries are shaded in light grey and light green, respectively. (4) Among the $3 X$ countries, 54 (including Argentina, China, Russia and the United States) did not conduct any prospective economic analysis. These countries are shaded in bright green. Three countries (Belgium, Denmark and Germany), shaded in dark green, conducted one simulation, and Australia and the Netherlands both conducted two studies and are shaded in dark blue [Colour figure can be viewed at wileyonlinelibrary.com]

and A4 in the Appendix). It was found that not every study included the terms 'costs', 'losses', or an aggregate definition of these two terms. The term 'cost' more often alluded to outbreak response costs (often referred to as 'direct' costs) like 'vaccination', 'cleaning' and 'disinfection'. Other notable descriptors included 'government' and 'compensation' or 'indemnity'. The term 'loss' more often related to agricultural production and included words like, 'milk', 'production', 'death' (related to animal deaths) and 'industry'. Other notable descriptors included 'government', 'economic' and 'financial'. Most obvious was that 'cost' includes losses and 'loss' includes costs, which is to be expected but convolutes the differentiation between cost and losses. Finally, words associated with outbreak response costs like 'disinfection' and 'vaccination' are found in the 'loss' definitions, and words associated with agricultural production such as 'export loss' and 'cattle industry' are found in the 'cost' definitions.

These comparisons qualitatively suggest that there are inconsistencies in the definitions of economic 'cost' and 'loss' across studies. While no statistical analysis was carried out, these figures illustrate the variability in parameters used to define cost and loss measures across studies. These results reiterate Perry \& Grace (2009) that varying diseases, methodologies and results make it difficult to draw general conclusions across studies. Lastly, one smaller but decidedly important takeaway from the review of economic literature was that some studies did not explicitly provide the year of reference for the currency values presented. This information is a simple detail which should always be clear in publications for ease of future use such as inflation calculations.

\section{4 | DISCUSSION}

These two scoping literature reviews originally aimed at simultaneously elucidating the most likely route of introduction and the associated economic impact associated with ASF, CSF and FMD. We were optimistic that a thorough review of the literature would implicate a 'smoking gun' that could be used as a starting point for further risk analyses and as a policy and decision making tool to prevent and prepare for a foreign animal disease (FAD) introduction. While this was not the outcome, we were able to extrapolate some useful results and develop a guide to key future research endeavours. 
In reviewing all risk evaluation literature, we cannot definitively identify the most likely route of introduction by specific region or disease. However, the majority of foreign risk evaluations that identified a specific pathway of introduction specified legal and illegal importations of live animals, animal products, animal feed, genetic material and bioterrorism; these results were reinforced by the U.S.specific risk evaluations.

Further, our review of the economic literature highlights that there were not any systematic retrospective economic analyses of the historic outbreaks, and too few simulations in the countries that are currently the most at risk for economic harm. This void makes preparation, preparedness and future planning challenging.

Taken together, the synergies of these two reviews tell us more about how any one of these diseases may enter the United States, but still very little about which disease is most likely to cause the greatest economic harm. In the United States, only one prospective study has been carried out for ASF and none for CSF, rendering it impossible to compare the outcomes. While numerous prospective economic studies have been published for the three FADs (primarily for European countries), we are unable to infer any meaningful conclusions for the United States, due to regional specificity and a myriad of disparate methodologies. Anecdotally, among the risk evaluation studies that analysed pathways of introduction related to a specific disease, ASFV was the most studied pathogen, which could indicate that this pathogen is the most concerning with respect to an incursion event. However, by a substantial margin, FMD has the largest number of economic impact studies. It is important to note that this relationship may be a relic of the temporality of disease outbreaks (e.g. the global spread of ASFV since 2018).

Our intention in undertaking this project is that we would use U.S. literature to guide our understanding of introduction risk and economic impact; however, the paucity of research on these topics compelled us to utilize all existing data globally. Conducting these reviews in tandem demonstrated substantial gaps in knowledge; however, it led to some additional broad generalizations regarding the potential impact of these diseases to the United States. First, there was not uniform consensus among the risk analyses for the potential disease introduction point or points within the United States. Second, while it is clear all of these diseases can cause significant economic harm, the variation in economic scope, definitions and data sources makes it difficult to aggregate economic study results for continent-wide or even global research. Third, our review pointed to a lack of correlation between the number of disease outbreaks and corresponding retrospective economic analyses, highlighting either a lack of data collection on previous outbreaks or a lack of motivation to publish such data. Fourth, despite the potentially large impact of an introduction of ASF, CSF or FMD on large sectors of the economy, few prospective (forecasting) economic studies have been peer-reviewed and published, leaving researchers and practitioners (including governments and institutions) without data or results to assess the cost effectiveness of different mitigation strategies in the case of an outbreak. Fifth, in addition to some oversight in including important details like relevant currency and reference years for economic values, there was a stark difference between what economic estimates like 'cost' and 'loss' were comprised of. Lastly, these reviews have not considered the potential role of feral swine in perpetuating and amplifying the spread of these diseases in the United States. Feral swine may be a significant variable relative to foreign animal diseases and could play a critical role in the potential economic impact associated with an outbreak event. Without at least a qualitative examination of the potential role of these invasive mammals, these reviews lack a crucial element in understanding the risk and certainly the economic impact. These six points leave governments and institutions without tools to assess the cost effectiveness of different mitigation strategies in the case of an outbreak resulting in potentially devastating consequences to the U.S.

\subsection{Disease risks in the United States}

The introduction of any of these diseases has the capacity to quickly impact the United States livestock industry, and the potential economic costs for a multispecies pathogen (i.e. FMDV) would be expected to be even larger. According to the 2017 U.S. Census of Agriculture, the 2017 value of livestock production in the United States alone was $\$ 77.2$ billion USD, $\$ 26.3$ billion USD and $\$ 36.7$ billion USD for cattle and calves, hogs and pigs, and milk, respectively (USDA, 2019a). In recent years, the United States has been either the world's largest or second largest exporter of pork and pork products and is the third-largest producer and consumer of pork and pork products globally (USDA, 2019b) with just under 200 million head sold (USDA, 2019a). In 2018, the United States was the fourth largest exporter of beef (USDA, 2019b, 2019c).

In addition to the economic impacts associated with an outbreak of ASF, CSF or FMD, the United States is home to at least six million invasive feral swine that roam in the majority of U.S. states (Lewis et al., 2019; USDA, 2020). Feral swine pose a threat to domestic livestock due to their high densities, rapid reproductive rate, and omnivorous and opportunistic diet (Brown et al., 2018) Additionally, anthropogenic activities (e.g. baiting, translocation and hunting pressures) and interaction with domestic livestock make feral swine an optimal vector for foreign and domestic animal disease spread. In some instances, feral swine live in urban and peri-urban environments and have been documented to feed in landfills. While there was not uniform consensus in the literature related to route of pathogen incursion, legal and illegal imports of animals and animal products were considered in some assessments to be the highest risk pathway of introduction, most commonly via air passengers or air passenger baggage (Brown \& Bevins, 2018a, 2018b, 2019). Introduction via other fomites such as shoes, clothing and supplies was one of the least common risks. Feral swine foraging at a landfill containing contaminated products could serve as an additional potential route for viral introduction and spillover. 
The paucity of information available on the highest risk and highest consequence routes for ASFV, CSFV and FMDV is problematic relative to developing targeted preventative methods, performing economic analyses for control methods and minimizing damage to related industries. Indeed, Buhnerkempe et al. (2014) showed that epidemic behaviour is strongly dependent on the introduction site of the pathogen. Insight for control and surveillance could be gained through an understanding of the most likely routes of introduction and the heterogeneity in disease spread processes that create the variation in outbreak sizes and corollary economic impacts, which is crucial for targeted preventative measures and resource allocation.

\section{5 | DATA AVAILABILITY STATEMENTS}

These reviews were based on the methodological guidance outlined by Peters et al. (2015) [29] and utilized the PRISMA methods (Preferred Reporting Items of Systematic Reviews and Meta-Analyses) [30, 31] for systematic scoping reviews. Specific text evaluated, search terms, and exclusion criteria, based on each PRISMA step are outlined for the risk assessment and economic literature reviews (respectively) in Table 1.

\section{ACKNOWLEDGEMENTS}

The findings and conclusions in this publication are those of the authors and should not be construed to represent any official USDA or U.S. Government determination or policy. This research was supported by the U.S. Department of Agriculture, Animal and Plant Health Inspection Service. We thank research librian Mary Foley for her assistance and advice in conducting literature searches and finding difficult to locate documents.

\section{ETHICAL APPROVAL}

The authors confirm to adhere to the ethical policies of the journal. No ethical approval was required as this is a review article with no original research data.

\section{CONFLICT OF INTEREST}

The authors do not have any conflicts of interest.

\section{ORCID}

Vienna R. Brown (iD https://orcid.org/0000-0002-2938-3987

\section{REFERENCES}

Adkin, A., Coburn, H., England, T., Hall, S., Hartnett, E., Marooney, C., Wooldridge, M., Eamon, W., Cooper, J., Cox, T., \& Seaman, M. (2004). Risk assessment for the illegal import of contaminated meat and meat products into Great Britain and the subsequent exposure of GB livestock (IIRA): Foot and mouth disease (FMD), classical swine fever (CSF), African swine fever (ASF), swine vesicular disease (SVD). Veterinary Laboratories Agency.

Alexandersen, S., Zhang, Z., Donaldson, A. I., \& Garland, A. J. M. (2003). The pathogenesis and diagnosis of foot-and-mouth disease. Journal of Comparative Pathology, 129(1), 1-36.
Anonymous. (2017). African swine fever in Eastern Europe: The risk to the UK. Veterinary Record, 181, 261-262. https://doi.org/10.1136/ vr.j4174

Antweiler, W. (2019). PACIFIC Exchange Rate Service. Foreign Currency Units per 1 U.S. Dollar, 1950-2018. http://fx.sauder.ubc.ca/

Babalobi, O. O., Olugasa, B. O., Oluwayelu, D. O., ljagbone, I. F., Ayoade, G. O., \& Agbede, S. A. (2007). Analysis and evaluation of mortality losses of the 2001 African swine fever outbreak, Ibadan, Nigeria. Tropical Animal Health and Production, 39(7), 533-542.

Bair-Brake, H., Bell, T., Higgins, A., Bailey, N., Duda, M., Shapiro, S., Eves, H., Marano, N., \& Galland, G. (2014). Is that a rodent in your luggage? A mixed method approach to describe bushmeat importation into the United States. Zoonoses and Public Health, 61(2), 97-104.

Bakkes, D. K., De Klerk, D., Latif, A. A., \& Mans, B. J. (2018). Integrative taxonomy of Afrotropical Ornithodoros (Ornithodoros) (Acari: Ixodida: Argasidae). Ticks and Tick-Borne Diseases, 9(4), 1006-1037.

Barasa, M., Catley, A., Machuchu, D., Laqua, H., Puot, E., Tap Kot, D., \& Ikiror, D. (2008). Foot-and-mouth disease vaccination in South Sudan: Benefit-Cost Analysis and livelihoods impact. Transboundary and Emerging Diseases, 55(8), 339-351.

Bates, T. W., Carpenter, T. E., \& Thurmond, M. C. (2003). Benefit-cost analysis of vaccination and preemptive slaughter as a means of eradicating foot-and-mouth disease. American Journal of Veterinary Research, 64(7), 805-812.

Bech-Nielsen, S., Bonilla, Q. P., \& Sanchez-Vizcaino, J. M. (1993). Benefitcost analysis of the current African swine fever eradication program in Spain and of an accelerated program. Preventive Veterinary Medicine, 17(3-4), 235-249.

Bellini, S., Rutili, D., \& Guberti, V. (2016). Preventive measures aimed at minimizing the risk of African swine fever virus spread in pig farming systems. Acta Veterinaria Scandinavica, 58(1), 1-10.

Belton, D. J. (2004). The macro-economic impact of a foot-and-mouth disease incursion in New Zealand. Developments in Biologicals, 119, 457.

Beltran-Alcrudo, D., Falco, J. R., Raizman, E., \& Dietze, K. (2019). Transboundary spread of pig diseases: The role of international trade and travel. BMC Veterinary Research, 15(1), 64.

Beltrán-Alcrudo, D., Lubroth, J., Depner, K., \& De La Rocque, S. (2008). African swine fever in the Caucasus. FAO Empres Watch, 1(8), 1-8.

Bender, J. B., Hueston, W., \& Osterholm, M. (2006). Recent animal disease outbreaks and their impact on human populations. Journal of Agromedicine, 11(1), 5-15.

Bennett, R., \& IJpelaar, J. (2005). Updated estimates of the costs associated with thirty four endemic livestock diseases in Great Britain: A note. Journal of Agricultural Economics, 56(1), 135-144.

Bergevoet, R. H. M., \& van Asseldonk, M. A. P. M. (2014). Economics of eradicating foot-and-mouth disease epidemics with alternative control strategies. Archivos De Medicina Veterinaria, 46(3), 381-388.

Beutlich, J., Hammerl, J. A., Appel, B., Nöckler, K., Helmuth, R., Jöst, K., Ludwig, M.-L., Hanke, C., Bechtold, D., \& Mayer-Scholl, A. (2015). Characterization of illegal food items and identification of foodborne pathogens brought into the European Union via two major German airports. International Journal of Food Microbiology, 209, 13-19.

Blackwell, J. H., Cliver, D. O., Callis, J. J., Heidelbaugh, N. D., Larkin, E. P., McKercher, P. D., \& Thayer, D. W. (1985). Foodborne viruses: Their importance and need for research. Journal of Food Protection, 48(8), 717-723.

Blake, A., Sinclair, M. T., \& Sugiyarto, G. (2003). Quantifying the impact of foot and mouth disease on tourism and the UK economy. Tourism Economics, 9(4), 449-465.

Blome, S., Gabriel, C., \& Beer, M. (2013). Pathogenesis of African swine fever in domestic pigs and European wild boar. Virus Research, 173(1), 122-130.

Blome, S., Staubach, C., Henke, J., Carlson, J., \& Beer, M. (2017). Classical swine fever-An updated review. Viruses, 9(4), E86. 
Boklund, A., Halasa, T., Christiansen, L. E., \& Enøe, C. (2013). Comparing control strategies against foot-and-mouth disease: Will vaccination be cost-effective in Denmark? Preventive Veterinary Medicine, 111(34), 206-219.

Boklund, A., Toft, N., Alban, L., \& Uttenthal, Å. (2009). Comparing the epidemiological and economic effects of control strategies against classical swine fever in Denmark. Preventive Veterinary Medicine, 90(3-4), 180-193.

Bosch, J., Iglesias, I., Muñoz, M. J., \& De la Torre, A. (2017). A cartographic tool for managing African swine fever in Eurasia: Mapping wild boar distribution based on the quality of available habitats. Transboundary and Emerging Diseases, 64(6), 1720-1733.

Bosch, J., Rodríguez, A., Iglesias, I., Muñoz, M. J., Jurado, C., SánchezVizcaíno, J. M., \& De la Torre, A. (2017). Update on the risk of introduction of African swine fever by wild boar into disease-free European Union countries. Transboundary and Emerging Diseases, 64(5), 1424-1432.

Breeze, R. (2004). Agroterrorism: Betting far more than the farm. Biosecurity and Bioterrorism: Biodefense Strategy, Practice, and Science, 2(4), 251-264.

Bronsvoort, B. D. C., Alban, L., \& Greiner, M. (2008). Quantitative assessment of the likelihood of the introduction of classical swine fever virus into the Danish swine population. Preventive Veterinary Medicine, 85(3-4), 226-240.

Brown, V. R., \& Bevins, S. N. (2018a). A review of classical swine fever virus and routes of introduction into the United States and the potential for virus establishment. Frontiers in Veterinary Science, 5, 31.

Brown, V. R., \& Bevins, S. N. (2018b). A review of African swine fever and the potential for introduction into the United States and the possibility of subsequent establishment in feral swine and native ticks. Frontiers in Veterinary Science, 5, 11.

Brown, V. R., \& Bevins, S. N. (2019). Potential role of wildlife in the USA in the event of a foot-and-mouth disease virus incursion. Veterinary Record, 184(24), 741.

Brown, V. R., Bowen, R. A., \& Bosco-Lauth, A. M. (2018). Zoonotic pathogens from feral swine that pose a significant threat to public health. Transboundary and Emerging Diseases, 65(3), 649-659.

Buhnerkempe, M. G., Tildesley, M. J., Lindström, T., Grear, D. A., Portacci, K., Miller, R. S., Lombard, J. E., Werkman, M., Keeling, M. J., Wennergren, U., \& Webb, C. T. (2014). The impact of movements and animal density on continental scale cattle disease outbreaks in the United States. PLoS One, 9(3), e91724.

Canadian Food Inspection Agency, Animal Health Risk Assessment Animal, Plant and Food Risk Analysis Network. (1999). Risk assessment on salted intestinal casing of swine (H5).

Cardoso de Carvalho Ferreira, H. (2013). Towards an improved understanding of African swine fever virus transmission (Doctoral dissertation). Utrecht University.

Carpenter, T. E., O'Brien, J. M., Hagerman, A. D., \& McCarl, B. A. (2011). Epidemic and economic impacts of delayed detection of foot-andmouth disease: A case study of a simulated outbreak in California. Journal of Veterinary Diagnostic Investigation, 23(1), 26-33.

Center for Epidemiology and Animal Health (CEAH). (2001). Pathway assessment of foot-and-mouth disease (FMD) risk to the United States: An evaluation in response to international FMD outbreaks in 2001. Executive Summary: USDA Animal Plant Health Inspection Service.

Center for Food Security and Public Health. (2016). Descriptions of incursions of foreign, transboundary, and emerging diseases. In Transboundary and emerging diseases of animals (pp. 1-2). Center for Food Security and Public Health.

Chaber, A. L., Allebone-Webb, S., Lignereux, Y., Cunningham, A. A., \& Marcus Rowcliffe, J. (2010). The scale of illegal meat importation from Africa to Europe via Paris. Conservation Letters, 3(5), 317-321.
Chen, Z., \& Jiang, X. (2017). Microbiological safety of animal wastes processed by physical heat treatment: An alternative to eliminate human pathogens in biological soil amendments as recommended by the food safety modernization act. Journal of Food Protection, 80(3), 392-405.

Corso, B. (1997). Likelihood of introducing selected exotic diseases to domestic swine in the continental United States of America through uncooked swill. Revue Scientifique Et Technique (International Office of Epizootics), 16(1), 199-206.

Costard, S., Jones, B. A., Martínez-López, B., Mur, L., de la Torre, A., Martínez, M., Sánchez-Vizcaíno, F., Sánchez-Vizcaíno, J.-M., Pfeiffer, D. U., \& Wieland, B. (2013). Introduction of African swine fever into the European Union through illegal importation of pork and pork products. PLoS One, 8(4), e61104.

Costard, S., Porphyre, V., Messad, S., Rakotondrahanta, S., Vidon, H., Roger, F., \& Pfeiffer, D. U. (2009). Multivariate analysis of management and biosecurity practices in smallholder pig farms in Madagascar. Preventive Veterinary Medicine, 92(3), 199-209.

Countryman, A. M., \& Hagerman, A. D. (2017). Retrospective economic analysis of foot-and-mouth disease eradication in the Latin American beef sector. Agribusiness, 33(2), 257-273.

Davidson, R. M. (1992). Assessment of risks posed by material of animal origin in mail and passengers' effects. Surveillance, 19, 25-26.

De la Torre, A., Bosch, J., Iglesias, I., Muñoz, M. J., Mur, L., MartínezLópez, B., Martínez, M., \& Sánchez-Vizcaíno, J. M. (2015). Assessing the risk of African swine fever introduction into the European Union by wild boar. Transboundary and Emerging Diseases, 62(3), 272-279.

de Melo, C. B., Pinheiro de Sá, M. E., Alves, F. F., McManus, C., Aragão, L. F., Belo, B. B., Campani, P. R., da Matta Ribeiro, A. C., Seabra, C. I., $\&$ Seixas, L. (2014). Profile of international air passengers intercepted with illegal animal products in baggage at Guarulhos and Galeão airports in Brazil. SpringerPlus, 3(1), 69.

De Vos, C. J., Saatkamp, H. W., Huirne, R. B. M., \& Dijkhuizen, A. A. (2003). The risk of the introduction of classical swine fever virus at regional level in the European Union: A conceptual framework. Revue Scientifique Et Technique-Office International Des Epizooties, 22(3), 795-810.

De Vos, C. J., Saatkamp, H. W., Nielen, M., \& Huirne, R. B. (2004). Scenario tree modeling to analyze the probability of classical swine fever virus introduction into member states of the European Union. Risk Analysis: An International Journal, 24(1), 237-253.

Dee, S. A., Bauermann, F. V., Niederwerder, M. C., Singrey, A., Clement, T., de Lima, M., Long, C., Patterson, G., Sheahan, M. A., Stoian, A. M. M., Petrovan, V., Jones, C. K., Jong, J. D., Ji, J. U., Spronk, G. D., Minion, L., Christopher-Hennings, J., Zimmerman, J. J., Rowland, R. R. R., ... Diel, D. G. (2018). Correction: Survival of viral pathogens in animal feed ingredients under transboundary shipping models. PLoS One, 13(11), e0208130.

Dejyong, T. (2016). Risk analysis of the potential introduction of African swine fever virus into Thailand by pig products from Italy, 2015 (qualitative risk assessment) (Doctoral dissertation, Colorado State University. Libraries).

Delgado, J., Pollard, S., Pearn, K., Snary, E. L., Black, E., Prpich, G., \& Longhurst, P. (2017). UK foot-and-mouth disease: A systemic risk assessment of existing controls. Risk Analysis, 37(9), 1768-1782.

DeNederlandscheBank. (2002). Exchange rates of the guilder 1982 Q1 to 2001 Q4. https://statistiek.dnb.nl/en/downloads/index.aspx\#/detai Is/exchange-rates-of-the-guilder-1982q1-to-2001q4/dataset/1af29 09e-4949-4f0e-bf3e-c6f6b43a0e51

Department for Environment Food and Rural Affairs, Veterinary Laboratories Agency. (2003). Risk assessment for the import of meat and meat products contaminated with foot-and-mouth disease virus into Great Britain and the subsequent exposure of GB livestock. 
Department for Environmental Food and Rural Affairs. (2006). Annual review of controls on imports of animal products: April 2005 - March 2006. http://www.defra.gov.uk/animalh/illegali/

Department for Environmental Food and Rural Affairs. (2008). Annual review of controls on imports of animal products April 2007 - March 2008. : Nobel House. http://www.defra.gov.uk

Department of Environment Food and Rural Affairs. (2017). A description of the UK system of controls on imports of live animals and products of animal origin and evaluation of its performance to protect public and animal health: April 2014-March 2016. www.gov.uk/government/publi cations

Department of Environment Food and Rural Affairs. (2018). Qualitative risk assessment: What is the risk of introducing African swine fever to the UK pig population from European Member States via human-mediated routes? https://assets.publishing.service.gov.uk/government/uploa ds/system/uploads/attachment_data/file/770081/asf-qra-novem ber2018.pdf

Dewey, C., Bottoms, K., Carter, N., \& Richardson, K. (2014). A qualitative study to identify potential biosecurity risks associated with feed delivery. Journal of Swine Health and Production, 22(5), 232-243.

Dietrich, R. A., \& Adams, L. G. (2000). Potential animal health concerns relative to cattle fever ticks, classical swine fever, and bovine brucellosis, with special emphasis on Texas. Texas Agricultural Experiment Station, Texas A \& M University System.

Dione, M., Ouma, E., Opio, F., Kawuma, B., \& Pezo, D. (2016). Qualitative analysis of the risks and practices associated with the spread of African swine fever within the smallholder pig value chains in Uganda. Preventive Veterinary Medicine, 135, 102-112.

Dufour, B., Plee, L., Moutou, F., Boisseleau, D., Chartier, C., Durand, B., Ganiere, J. P., Guillotin, J., Lancelot, R., Saegerman, C., Thebault, A., Hattenberger, A. M., \& Toma, B. (2011). A qualitative risk assessment methodology for scientific expert panels. Revue Scientifique Et Technique (International Office of Epizootics), 30, 673-681.

Edwards, S., Fukusho, A., Lefevre, P. C., Lipowski, A., Pejsak, Z., Roehe, P., \& Westergaard, J. (2000). Classical swine fever: The global situation. Veterinary Microbiology, 73(2-3), 103-119.

EFSA Panel on Animal Health and Welfare (AHAW). (2014). Scientific opinion on African swine fever. EFSA Journal, 12(4), 3628.

Elbakidze, L., Highfield, L., Ward, M., McCarl, B. A., \& Norby, B. (2009). Economics analysis of mitigation strategies for FMD introduction in highly concentrated animal feeding regions. Review of Agricultural Economics, 31(4), 931-950.

Elbakidze, L., \& McCarl, B. A. (2006). Animal disease pre-event preparedness versus post-event response: When is it economic to protect? Journal of Agricultural and Applied Economics, 38(1379-2016-112836), 327-336.

European Central Bank. (2019). Historical reference rates. https://www. ecb.europa.eu/stats/policy_and_exchange_rates/euro_reference_ exchange_rates/html/index.en.html

European Food Safety Authority. (2006). Risk assessment on foot-andmouth disease. European Food Safety Authority Journal, 313, 1-34.

Falk, H., Dürr, S., Hauser, R., Wood, K., Tenger, B., Lörtscher, M., \& Schuepbach-Regula, G. (2013). Illegal import of bushmeat and other meat products into Switzerland on commercial passenger flights. Revue Scientifique Et Technique-Office International Des Epizooties, 32(3), 727-739.

FAO (Food and Agriculture Organization of the United Nations). (2012). Foot-and-mouth disease frequently asked questions. http://www.fao. org/3/an384e/an384e00.pdf

FAO. (2019a). Animal production. http://www.fao.org/animal-produ ction/en/

FAO. (2019b). ASF situation in Asia update. http://www.fao.org/ag/again fo/programmes/en/empres/ASF/situation_update.html
FAO. (2019c). FAOSTAT: Data: Live animals. http://www.fao.org/faostat/ en/\#data

Fasina, F. O., Lazarus, D. D., Spencer, B. T., Makinde, A. A., \& Bastos, A. D. (2012). Cost implications of African swine fever in smallholder farrow-to-finish units: Economic benefits of disease prevention through biosecurity. Transboundary and Emerging Diseases, 59(3), 244-255.

Federal Inter-agency Working Group. (2003). Animal disease risk assessment, prevention, and control act of 2001 (PL 107-9) Final Report.

Fekede, R. J., Van Gils, H., Huang, L., \& Wang, X. (2019). High probability areas for ASF infection in China along the Russian and Korean borders. Transboundary and Emerging Diseases, 66(2), 852-864.

Forbes, R. N., Sanson, R. L., \& Morris, R. S. (1994). Application of subjective methods to the determination of the likelihood and consequences of the entry of foot-and-mouth disease into New Zealand. New Zealand Veterinary Journal, 42(3), 81-88.

Gale, P. (2004). Risks to farm animals from pathogens in composted catering waste containing meat. Veterinary Record, 155(3), 77-82.

Gamado, K., Marion, G., \& Porphyre, T. (2017). Data-driven risk assessment from small scale epidemics: Estimation and model choice for spatio-temporal data with application to a classical swine fever outbreak. Frontiers in Veterinary Science, 4, 16.

Garner, M. G., \& Lack, M. B. (1995). Modelling the potential impact of exotic diseases on regional Australia. Australian Veterinary Journal, 72(3), 81-87.

Garner, M. G., Whan, I. F., Gard, G. P., \& Phillips, D. (2001). The expected economic impact of selected exotic diseases on the pig industry of Australia. Revue Scientifique Et Technique-Office International Des Epizooties, 20(3), 671-686.

Goldsmith, T. J., Culhane, M. R., Sampedro, F., \& Cardona, C. J. (2017). Proactive risk assessments and the Continuity of Business principles: Perspectives on this novel, combined approach to develop guidance for the permitted movement of agricultural products during a foot-and-mouth disease outbreak in the United States. Frontiers in Veterinary Science, 3, 117.

Golnar, A. J., Martin, E., Wormington, J. D., Kading, R. C., Teel, P. D., Hamer, S. A., \& Hamer, G. L. (2019). Reviewing the potential vectors and hosts of African swine fever virus transmission in the United States. Vector-Borne and Zoonotic Diseases, 19(7), 512-524.

Grubman, M. J., \& Baxt, B. (2004). Foot-and-mouth disease. Clinical Microbiology Reviews, 17(2), 465-493.

Guinat, C., Gogin, A., Blome, S., Keil, G., Pollin, R., Pfeiffer, D. U., \& Dixon, L. (2016). Transmission routes of African swine fever virus to domestic pigs: Current knowledge and future research directions. The Veterinary Record, 178(11), 262.

Halasa, T., Boklund, A., Bøtner, A., Toft, N., \& Thulke, H. H. (2016). Simulation of spread of African swine fever, including the effects of residues from dead animals. Frontiers in Veterinary Science, 3, 6.

Halasa, T., Bøtner, A., Mortensen, S., Christensen, H., Toft, N., \& Boklund, A. (2016). Simulating the epidemiological and economic effects of an African swine fever epidemic in industrialized swine populations. Veterinary Microbiology, 193, 7-16.

Hartley, M. (2010). Qualitative risk assessment of the role of the feral wild boar (Sus scrofa) in the likelihood of incursion and the impacts on effective disease control of selected exotic diseases in England. European Journal of Wildlife Research, 56(3), 401-410.

Hartnett, E., Adkin, A., Seaman, M., Cooper, J., Watson, E., Coburn, H., England, T., Marooney, C., Cox, A., \& Wooldridge, M. (2007). A quantitative assessment of the risks from illegally imported meat contaminated with foot and mouth disease virus to Great Britain. Risk Analysis: An International Journal, 27(1), 187-202.

Hernández-Jover, M., Schembri, N., Holyoake, P. K., Toribio, J. A. L., \& Martin, P. A. J. (2016). A comparative assessment of the risks of introduction and spread of foot-and-mouth disease among different pig sectors in Australia. Frontiers in Veterinary Science, 3, 85. 
Herrera-lbatá, D. M., Martínez-López, B., Quijada, D., Burton, K., \& Mur, L. (2017). Quantitative approach for the risk assessment of African swine fever and Classical swine fever introduction into the United States through legal imports of pigs and swine products. PLoS One, 12(8), e0182850.

Hong, K., Lee, G., \& Pak, S. (2005). A quantitative modeling approach to estimate the risks posed by the smuggled animal products contaminated with foot-and-mouth disease (FMD) virus. Korean Journal of Veterinary Research, 45(2), 223.

Hop, G. E., Mourits, M. C., Oude Lansink, A. G. J. M., \& Saatkamp, H. W. (2016). Simulation of cross-border impacts resulting from classical swine fever epidemics within the Netherlands and Germany. Transboundary and Emerging Diseases, 63(1), e80-e102.

Huang, Z. Y., van Langevelde, F., Honer, K. J., Naguib, M., \& de Boer, W. F. (2017). Regional level risk factors associated with the occurrence of African swine fever in West and East Africa. Parasites \& Vectors, 10(1), 16.

Hwang, J., Lee, K., Walsh, D., Kim, S., Sleeman, J. M., \& Lee, H. (2018). Semi-quantitative assessment of disease risks at the human, livestock, wildlife interface for the Republic of Korea using a nationwide survey of experts: A model for other countries. Transboundary and Emerging Diseases, 65(1), e155-e164.

Jansen, W., Merkle, M., Daun, A., Flor, M., Grabowski, N. T., \& Klein, G. (2016). The quantity and quality of illegally imported products of animal origin in personal consignments into the European Union seized at two German airports between 2010 and 2014. PLoS One, 11(2), e0150023.

Jarvis, S. (2018). The risk from African swine fever. The Veterinary Record, $183,515$.

Jemberu, W. T., Mourits, M. C., Woldehanna, T., \& Hogeveen, H. (2014). Economic impact of foot and mouth disease outbreaks on smallholder farmers in Ethiopia. Preventive Veterinary Medicine, 116(1-2), 26-36.

Jin, Y. (2017). Development of word cloud generator software based on python. Procedia Engineering, 174, 788-792.

Jurado, C., Martínez-Avilés, M., De La Torre, A., Štukelj, M., de Carvalho Ferreira, H. C., Cerioli, M., Sánchez-Vizcaíno, J. M., \& Bellini, S. (2018). Relevant measures to prevent the spread of African swine fever in the European Union domestic pig sector. Frontiers in Veterinary Science, 5, 77.

Jurado, C., Paternoster, G., Martínez-López, B., Burton, K., \& Mur, L. (2019). Could African swine fever and classical swine fever viruses enter into the United States via swine products carried in air passengers' luggage? Transboundary and Emerging Diseases, 66(1), 166-180.

Knight-Jones, T. J. D., \& Rushton, J. (2013). The economic impacts of foot and mouth disease-What are they, how big are they and where do they occur? Preventive Veterinary Medicine, 112(3-4), 161-173.

Kyyrö, J., Sahlström, L., \& Lyytikäinen, T. (2017). Assessment of the risk of African swine fever introduction into Finland using NORA-A rapid tool for semi-quantitative assessment of the risk. Transboundary and Emerging Diseases, 64(6), 2113-2125.

Le, V. P., Jeong, D. G., Yoon, S.-W., Kwon, H.-M., Trinh, T. B. N., Nguyen, T. L., Bui, T. T. N., Oh, J., Kim, J. B., Cheong, K. M., Van Tuyen, N., Bae, E., Vu, T. T. H., Yeom, M., Na, W., \& Song, D. (2019). Outbreak of African swine fever, Vietnam, 2019. Emerging Infectious Diseases, 25(7), 1433. https://doi.org/10.3201/eid2507.190303

Lewis, J. S., Corn, J. L., Mayer, J. J., Jordan, T. R., Farnsworth, M. L., Burdett, C. L., VerCauteren, K. C., Sweeney, S. J., \& Miller, R. S. (2019). Historical, current, and potential population size estimates of invasive wild pigs (Sus scrofa) in the United States. Biological Invasions, 21(7), 2373-2384. https://doi.org/10.1007/s10530-01901983-1
MacDiarmid, S. C. (1991). The importation into New Zealand of meat and meat products: a review of the risks to animal health. Ministry of Agriculture and Fisheries.

Mahul, O., \& Durand, B. (2000). Simulated economic consequences of foot-and-mouth disease epidemics and their public control in France. Preventive Veterinary Medicine, 47(1-2), 23-38.

Mangen, M. J., \& Burrell, A. M. (2003). Who gains, who loses? Welfare effects of classical swine fever epidemics in the Netherlands. European Review of Agricultural Economics, 30(2), 125-154.

Mangen, M. J., Burrell, A. M., \& Mourits, M. C. M. (2004). Epidemiological and economic modelling of classical swine fever: Application to the 1997/1998 Dutch epidemic. Agricultural Systems, 81(1), 37-54.

Martínez-López, B., Perez, A. M., De la Torre, A., \& Rodriguez, J. S. V. (2008). Quantitative risk assessment of foot-and-mouth disease introduction into Spain via importation of live animals. Preventive Veterinary Medicine, 86(1-2), 43-56.

Martínez-López, B., Perez, A. M., Feliziani, F., Rolesu, S., Mur, L., \& Sánchez-Vizcaíno, J. M. (2015). Evaluation of the risk factors contributing to the African swine fever occurrence in Sardinia, Italy. Frontiers in Microbiology, 6, 314.

Martínez-López, B., Perez, A. M., \& Sanchez-Vizcaino, J. M. (2009). A stochastic model to quantify the risk of introduction of classical swine fever virus through import of domestic and wild boars. Epidemiology \& Infection, 137(10), 1505-1515.

McCauley, H., Aulaqi, N., Sundquist, W. B., \& New, J. (1978). Studies on economic impact of foot-and-mouth disease in the United States. Preliminary report of on-going research at the University of Minnesota. In P. R. Ellis, A. P. M. Shaw, \& A. J. Stephens (Eds.), New techniques in veterinary epidemiology and economics (pp. 132-166). Department of Agriculture, University of Reading.

Melo, C. B. D., Belo, B. B., Sá, M. E. P. D., McManus, C. M., \& Seixas, L. (2018). Illegal animal-origin products seized in baggage from international flights at São Paulo Guarulhos airport (GRU/SBGR), Brazil. Ciência Animal Brasileira, 19, 1-9.

Meuwissen, M. P., Horst, S. H., Huirne, R. B., \& Dijkhuizen, A. A. (1999). A model to estimate the financial consequences of classical swine fever outbreaks: Principles and outcomes. Preventive Veterinary Medicine, 42(3-4), 249-270. https://doi.org/10.1016/S0167-5877 (99)00079-3

Middlemiss, C. (2018). African swine fever: An increasing risk to UK pigs.

Miller, M., Liu, L., Shwiff, S., \& Shwiff, S. (2019). Macroeconomic impact of foot-and-mouth disease vaccination strategies for an outbreak in the Midwestern United States: A computable general equilibrium. Transboundary and Emerging Diseases, 66(1), 156-165. https://doi. org/10.1111/tbed.12995

Miller, R. S., Sweeney, S. J., Slootmaker, C., Grear, D. A., Di Salvo, P. A., Kiser, D., \& Shwiff, S. A. (2017). Cross-species transmission potential between wild pigs, livestock, poultry, wildlife, and humans: Implications for disease risk management in North America. Scientific Reports, 7(1), 1-14. https://doi.org/10.1038/s41598-017-07336-z

Mintiens, K., Laevens, H., Dewulf, J., Boelaert, F., Verloo, D., \& Koenen, F. (2003). Risk analysis of the spread of classical swine fever virus through 'neighbourhood infections' for different regions in Belgium. Preventive Veterinary Medicine, 60(1), 27-36. https://doi.org/10.1016/ S0167-5877(03)00080-1

Moennig, V. (2000). Introduction to classical swine fever: Virus, disease and control policy. Veterinary Microbiology, 73(2-3), 93-102. https:// doi.org/10.1016/S0378-1135(00)00137-1

Moher, D., Liberati, A., Tetzlaff, J., Altman, D. G., \& Prisma Group. (2009). Preferred reporting items for systematic reviews and meta-analyses: The PRISMA statement. PLoS Medicine, 6(7), e1000097.

Moher, D., Shamseer, L., Clarke, M., Ghersi, D., Liberati, A., Petticrew, M., Shekelle, P., \& Stewart, L. A. (2015). Preferred reporting items for systematic review and meta-analysis protocols (PRISMA-P) 
2015 statement. Systematic Reviews, 4(1), 1. https://doi.org/10.1186/ 2046-4053-4-1

Moutou, F., Dufour, B., \& Ivanov, Y. (2001). A qualitative assessment of the risk of introducing foot and mouth disease into Russia and Europe from Georgia, Armenia and Azerbaijan. Revue Scientifique Et Technique (International Office of Epizootics), 20(3), 723-730. https:// doi.org/10.20506/rst.20.3.1307

Mur, L., Martínez-López, B., Costard, S., de la Torre, A., Jones, B. A., Martínez, M., Sánchez-Vizcaíno, F., Muñoz, M. J., Pfeiffer, D. U., Sánchez-Vizcaíno, J. M., \& Wieland, B. (2014). Modular framework to assess the risk of African swine fever virus entry into the European Union. BMC Veterinary Research, 10(1), 145.

Mur, L., Martínez-López, B., Martínez-Avilés, M., Costard, S., Wieland, B., Pfeiffer, D. U., \& Sánchez-Vizcaíno, J. M. (2012). Quantitative risk assessment for the introduction of African swine fever virus into the European Union by legal import of live pigs. Transboundary and Emerging Diseases, 59(2), 134-144. https://doi. org/10.1111/j.1865-1682.2011.01253.x

Mur, L., Martínez-López, B., \& Sánchez-Vizcaíno, J. M. (2012). Risk of African swine fever introduction into the European Union through transport-associated routes: Returning trucks and waste from international ships and planes. BMC Veterinary Research, 8(1), 149. https:// doi.org/10.1186/1746-6148-8-149

National Agricultural Biosecurity Center. (2004). Pathways analysis of classical swine fever (CSF) risk to the United States. http://www.k-state. edu/nabc/docs/2004-PA-CSF.pdf

Niedbalski, W. I. E. S. Ł. A. W., Fitzner, A., \& Bulenger, K. (2019). Recent progress in vaccines against foot-and-mouth disease. Medycyna Weterynaryjna, 75(09), 528-533.

Nigsch, A., Costard, S., Jones, B. A., Pfeiffer, D. U., \& Wieland, B. (2013). Stochastic spatio-temporal modelling of African swine fever spread in the European Union during the high risk period. Preventive Veterinary Medicine, 108(4), 262-275.

Noordhuizen, J., Surborg, H., \& Smulders, F. J. (2013). On the efficacy of current biosecurity measures at EU borders to prevent the transfer of zoonotic and livestock diseases by travelers. Veterinary Quarterly, 33(3), 161-171.

OIE. (2019). History. http://www.oie.int/about-us/history/

OIE. (2020). World Animal Health Information Database (WAHIS). Interface. https://www.oie.int/wahis_2/public/wahid.php/Wahid home/Home/indexcontent/newlang/en

Pendell, D. L., Leatherman, J. C., Schroeder, T. C., \& Alward, G. S. (2007). The economic impacts of a foot-and-mouth disease outbreak: A regional analysis. Journal of Agricultural and Applied Economics, 39(1379-2016-113499), 19-33.

Penrith, M. L. (2009). African swine fever. Onderstepoort Journal of Veterinary Research, 76(1), 91-95.

Perry, B., \& Grace, D. (2009). The impacts of livestock diseases and their control on growth and development processes that are pro-poor. Philosophical Transactions of the Royal Society B: Biological Sciences, 364(1530), 2643-2655.

Peters, M. D., Godfrey, C. M., Khalil, H., Mclnerney, P., Parker, D., \& Soares, C. B. (2015). Guidance for conducting systematic scoping reviews. International Journal of Evidence-Based Healthcare, 13(3), 141-146.

Pharo, H. J., \& Biosecurity Authority. (2002). Determination of the acceptable risk of introduction of FMD virus in passenger luggage following the UK outbreak in 2001. Epidemiology Chapter Programme of the Australian College of Veterinary Scientists Science Week, 4-6.

Pharo, H. J. (2002). Foot-and-mouth disease: An assessment of the risks facing New Zealand. New Zealand Veterinary Journal, 50(2), 46-55.

Porphyre, T., Boden, L. A., Correia-Gomes, C., Auty, H. K., Gunn, G. J., $\&$ Woolhouse, M. E. (2014). How commercial and non-commercial swine producers move pigs in Scotland: A detailed descriptive analysis. BMC Veterinary Research, 10(1), 140.

Randolph, T. F., Perry, B. D., Benigno, C. C., Santos, I. J., Agbayani, A. L., Coleman, P. G., Webb, R. F., \& Gleeson, L. J. (2002). The economic impact of foot and mouth disease control and eradication in the Philippines. Revue Scientifique Et Technique (International Office of Epizootics, 21(3), 645.

Randolph, T. F., Schelling, E., Grace, D., Nicholson, C. F., Leroy, J. L., Cole, D. C., Demment, M. W., Omore, A., Zinsstag, J., \& Ruel, M. (2007). Invited review: Role of livestock in human nutrition and health for poverty reduction in developing countries. Journal of Animal Science, 85(11), 2788-2800.

Rendleman, C. M., \& Spinelli, F. J. (1999). The costs and benefits of animal disease prevention: The case of African swine fever in the US. Environmental Impact Assessment Review, 19(4), 405-426.

Rodeia, S. P. (2008). Foot and mouth disease: Assessing the risk of introduction into the $\mathrm{EU}$ and the reduction of risk through interventions in infected countries. Transboundary and Emerging Diseases, 55(1), 1-87.

Roelandt, S., Van der Stede, Y.,D'hondt, B., \& Koenen, F. (2017). The assessment of African swine fever virus risk to Belgium early 2014, using the quick and semi-quantitative Pandora screening protocol. Transboundary and Emerging Diseases, 64(1), 237-249.

Saatkamp, H. W., Berentsen, P. B. M., \& Horst, H. S. (2000). Economic aspects of the control of classical swine fever outbreaks in the European Union. Veterinary Microbiology, 73(2-3), 221-237.

Sánchez-Vizcaíno, J. M., Martinez-Lopez, B., Martinez-Aviles, M., Martins, C., Boinas, F., Vial, L., Michaud, V., Jori, F., Etter, E., Albina, E., \& Roger, F. (2009). Scientific report submitted to EFSA on African swine fever (pp. 1-141).

Schijven, J., Rijs, G. B., \& de Roda Husman, A. M. (2005). Quantitative risk assessment of FMD virus transmission via water. Risk Analysis: An International Journal, 25(1), 13-21.

Schoenbaum, M. A., \& Disney, W. T. (2003). Modeling alternative mitigation strategies for a hypothetical outbreak of foot-and-mouth disease in the United States. Preventive Veterinary Medicine, 58(1-2), 25-52.

Schroeder, T. C., Pendell, D. L., Sanderson, M. W., \& McReynolds, S. (2015). Economic impact of alternative FMD emergency vaccination strategies in the Midwestern United States. Journal of Agricultural and Applied Economics, 47(1), 47-76.

Scientific Committee of the FASFC. (2018). Urgent advice 16-2018 of the scientific committee of the FASFC on the risk of spreading of the African swine fever virus in the Belgian wildlife and spill-over in the Belgian swine sector.

Senturk, B., \& Yalcin, C. (2008). Production losses due to endemic footand-mouth disease in cattle in Turkey. Turkish Journal of Veterinary and Animal Sciences, 32(6), 433-440.

Şenturk, B., Yalcin, C., \& Akcay, A. (2016). Analysis of risk factors in the management of foot-and-mouth disease in Turkey. Turkish Journal of Veterinary and Animal Sciences, 40(1), 1-6.

Shih, T. H., Chou, C. C., \& Morley, R. S. (2005). Monte Carlo simulation of animal-product violations incurred by air passengers at an international airport in Taiwan. Preventive Veterinary Medicine, 68(2-4), 115-122. https://doi.org/10.1016/j.prevetmed.2004.11.010

Slingluff, J., Sampedro, F., \& Goldsmith, T. J. (2014). Risk assessment for the transmission of foot-and-mouth disease via movement of swine and cattle carcasses from FMD-infected premises to a disposal site.

Sugiura, K., \& Haga, T. (2018). A rapid risk assessment of African swine fever introduction and spread in Japan based on expert opinions. Journal of Veterinary Medical Science, 80, 1743-1746. https://doi. org/10.1292/jvms.18-0543

Sutmoller, P., \& Olascoaga, R. C. (2003). The risks posed by the importation of animals vaccinated against foot and mouth disease and 
products derived from vaccinated animals. Revue Scientifique Et Technique-Office International Des Epizooties, 22(3), 823-835.

Terpstra, C. (1987). Epizootiology of swine fever. Veterinary Quarterly, 9(Supp. 1), 50-60. https://doi.org/10.1080/01652176.1987.969 4138

Thompson, D. K., Muriel, P., Russell, D., Osborne, P., Bromley, A., Rowland, M., Creigh-tyte, S., \& Brown, C. (2002). Economic costs of the foot and mouth disease outbreak in the United Kingdom in 2001. Revue Scientifique Et Technique-Office International Des Epizooties, 21(3), 675-687. https://doi.org/10.20506/rst.21.3. 1353

Tomley, F. M., \& Shirley, M. W. (2009). Livestock infectious diseases and zoonoses. Philosophical Transactions of the Royal Society B: Biological Sciences, 364(1530), 2637-2642. https://doi.org/10.1098/ rstb. 2009.0133

United Nations. Population Databases. (2020). United Nations, Department of Economic and Social Affairs, Population. https://www. un.org/en/development/desa/population/publications/database/ index.asp

United States Bureau of Labor Statistics. (2019). Historical CPI-U, June 2019. https://www.bls.gov/cpi/tables/supplemental-files/historical -cpi-u-201906.pdf

United States Department of Agriculture. (1994). Animal Plant Health Inspection Service, Centers for Epidemiology and Animal Health. Sources of outbreaks and hazard categorization of modes of virus transmission: Foot-and-mouth disease.

United States Department of Agriculture. (2007). Animal Plant Health Inspection Service, Centers for Epidemiology and Animal Health. Sources of outbreaks and hazard categorization of modes of virus transmission: Foot-and-mouth disease.

United States Department of Agriculture. (2014a). Pathways assessment: Entry assessment for exotic viral pathogens of swine, pp. 1-198.

United States Department of Agriculture. (2019a). Census of Agriculture: 2017 census volume 1, chapter 1: U.S. National Level Data. National Agricultural Statistics Service. https://www.nass. usda.gov/Publications/AgCensus/2017/Full_Report/Volume_1, Chapter_1_US/

United States Department of Agriculture. (2019b). Animal Products-Hogs and Pork. Economic Research Service. https://www.ers.usda.gov/ topics/animal-products/hogs-pork/

United States Department of Agriculture. (2019c). Sector at a Glance: U.S. Beef and Cattle Trade. Economic Research Service. https://www. ers.usda.gov/topics/animal-products/cattle-beef/sector-at-a-glanc e/\#beef

United States Department of Agriculture, Animal Plant Health Inspection Service. (2002). Classical swine fever-Epidemiological situation (pp. 1-11).

United States Department of Agriculture, Animal Plant Health Inspection Service. (2013). Risk analysis: Foot-and-mouth disease (FMD) risk from importation of fresh (chilled or frozen), maturated, deboned beef from a region in Brazil into the United States.

United States Department of Agriculture, Animal Plant Health Inspection Service, Centers for Epidemiology and Animal Health. (1995) Risk assessment of the practice of feeding recycled commodities to domesticated swine in the U.S.

United States Department of Agriculture, Animal Plant Health Inspection Service, Centers for Epidemiology and Animal Health. (1998a). Potential economic impact of hog cholera in the U.S., 1998. (pp. 1-111).

United States Department of Agriculture, Animal Plant Health Inspection Service, Centers for Epidemiology and Animal Health. (1998b). Biological and economic consequences of a classical swine fever incursion in the United States.
United States Department of Agriculture, Animal Plant Health Inspection Service, Centers for Epidemiology and Animal Health. (1998c). Benefits to the United States of potential fresh, chilled, and frozen pork imports, imports of live breeding swine, and imports of swine semen from EU countries not currently recognized as CSF free.

United States Department of Agriculture, Animal Plant Health Inspection Service, Centers for Epidemiology and Animal Health. (1998d). Risk factors in the European Union regarding CSF and regionalization.

United States Department of Agriculture, Animal Plant Health Inspection Service, Centers for Epidemiology and Animal Health. (1998e). Biological and economic risk analysis: Risk management options for imports of breeding swine, swine semen and fresh, chilled, and frozen pork from the European Union.

United States Department of Agriculture, Animal Plant Health Inspection Service, Centers for Epidemiology and Animal Health. (1999). Risk Analysis Report Series: The analysis of the risk of classical swine fever from imports of pork, breeding animals, and semen from the European Union.

United States Department of Agriculture, Animal Plant Health Inspection Service, Centers for Epidemiology and Animal Health. (2000). Risk analysis for importation of classical swine fever virus in swine and swine products from the European Union (pp. 1-115).

United States Department of Agriculture, Animal Plant Health Inspection Service, Centers for Epidemiology and Animal Health. (2012). State rankings for the introduction of foot-and-mouth disease.

United States Department of Agriculture, Animal Plant Health Inspection Service, Centers for Epidemiology and Animal Health. (2014b). Risk analysis: Risk of importing foot-and-mouth disease in susceptible species and products from a region of Patagonia, Argentina.

United States Department of Agriculture, Animal Plant Health Inspection Service, Centers for Epidemiology and Animal Health. (2018). Risk assessment of ready-to-eat pork products from premises previous to the establishment of a control area as a source of infection of susceptible livestock during a foot-and-mouth disease outbreak in the United States.

United States Department of Agriculture. Animal and Plant Health Inspection Service. (2020). History of feral swine in the Americas. https://www.aphis.usda.gov/aphis/ourfocus/wildlifedamage/opera tional-activities/feral-swine/sa-fs-history

United States Department of the Treasury. (2019). Treasury reporting rates of exchange: Historical rates. https://www.fiscal.treasury.gov/ reports-statements/treasury-reporting-rates-exchange/historical. $\mathrm{html}$

Whyte, C. (2006). Science and biosecurity-monitoring the effectiveness of biosecurity interventions at New Zealand's borders. Royal Society of New Zealand, Miscellaneous Series, 67, 27-36.

Wieland, B., Batsukh, B., Enktuvshin, S., Odontsetseg, N., \& Schuppers, M. (2015). Foot-and-mouth disease risk assessment in MongoliaLocal expertise to support national policy. Preventive Veterinary Medicine, 120(1), 115-123.

Wieland, B., Dhollander, S., Salman, M., \& Koenen, F. (2011). Qualitative risk assessment in a data-scarce environment: A model to assess the impact of control measures on spread of African swine fever. Preventive Veterinary Medicine, 99(1), 4-14.

Wooldridge, M., Hartnett, E., Cox, A., \& Seaman, M. (2006). Quantitative risk assessment case study: Smuggled meats as disease vectors. Revue Scientifique Et Technique-Office International Des Epizooties, 25(1), 105

Wormington, J. D., Golnar, A., Poh, K. C., Kading, R. C., Martin, E., Hamer S. A., \& Hamer, G. L. (2019). Risk of African swine fever virus sylvatic establishment and spillover to domestic swine in the United States. Vector-Borne and Zoonotic Diseases, 19(7), 506-511. 
Yang, P. C., Chu, R. M., Chung, W. B., \& Sung, H. T. (1999). Epidemiological characteristics and financial costs of the 1997 foot-and-mouth disease epidemic in Taiwan. Veterinary Record, 145(25), 731-734.

Zhou, X., Li, N., Luo, Y., Liu, Y. E., Miao, F., Chen, T., Zhang, S., Cao, P., Li, X., Tian, K., Qiu, H.-J., \& Hu, R. (2018). Emergence of African swine fever in China, 2018. Transboundary and Emerging Diseases, 65(6), 1482-1484. https://doi.org/10.1111/tbed.12989
How to cite this article: Brown VR, Miller RS, McKee SC, et al. Risks of introduction and economic consequences associated with African swine fever, classical swine fever and foot-andmouth disease: A review of the literature. Transbound Emerg Dis. 2021;68:1910-1965. https://doi.org/10.1111/tbed.13919 


\section{APPENDIX}

TABLE A1 Description of included studies of risk evaluations

\begin{tabular}{|c|c|c|c|c|}
\hline Authors \& date & Pathogen & Type of study & Assessed pathways of introduction & Highest risk pathway of introduction \\
\hline \multicolumn{5}{|l|}{ U.S. Assessments } \\
\hline $\begin{array}{l}\text { Blackwell } \\
\text { et al. (1985) }\end{array}$ & ASFV & Qualitative & $\begin{array}{l}\text { Feeding garbage to livestock, international trade of food } \\
\text { products of animal origin }\end{array}$ & Not identified \\
\hline USDA (1995) & ASFV & Quantitative & $\begin{array}{l}\text { Feeding household waste contaminated by contraband or } \\
\text { legal imports to domestic swine }\end{array}$ & $\begin{array}{l}\text { Contraband contaminated household waste being fed to } \\
\text { domestic swine }\end{array}$ \\
\hline Corso (1997) & ASFV & Quantitative & $\begin{array}{l}\text { Uncooked swill, (Due to legal/illegal importation of food items } \\
\text { of animal origin by way of traveller or by mail, subsequently } \\
\text { discarded in household waste) }\end{array}$ & Uncooked contaminated swill feeding \\
\hline USDA (2014a) & ASFV & Qualitative & $\begin{array}{l}\text { Dietary supplements/traditional medicines, veterinary } \\
\text { vaccines and miscellaneous biological products, } \\
\text { unprocessed animal feed ingredients derived from plants } \\
\text { or plant products, commercial swine meat and meat (by) } \\
\text { products for human consumption, non-rendered pet food } \\
\text { treats and chews, bushmeat, non-regulated garbage, } \\
\text { livestock and germplasm, humans, other live animals, } \\
\text { airborne, inanimate articles that may serve as fomites, } \\
\text { vehicular fomites, equipment, garbage (every possible } \\
\text { pathway) }\end{array}$ & Diagnostic samples collected from swine or ruminants \\
\hline $\begin{array}{l}\text { Chen and Jiang } \\
\text { (2017) }\end{array}$ & ASFV & Qualitative & Animal waste in manure & Not identified \\
\hline $\begin{array}{l}\text { Herrera-Ibatá } \\
\text { et al. (2017) }\end{array}$ & ASFV & Quantitative & Legal importation of swine and swine products & Legal importations of live pigs \\
\hline $\begin{array}{l}\text { Brown and Bevins } \\
\text { (2018b) }\end{array}$ & ASFV & Qualitative & $\begin{array}{l}\text { Illegal/legal movement/importation of live animals or their } \\
\text { products, by-products, or animal feed or bioterrorism }\end{array}$ & $\begin{array}{l}\text { Illegal/legal movement of live animals or their products, } \\
\text { by-products, or animal feed or bioterrorism }\end{array}$ \\
\hline Dee et al. (2018) & ASFV & Quantitative & Importation of feed ingredients & Not identified \\
\hline
\end{tabular}

\begin{tabular}{|c|c|c|c|c|}
\hline Golnar et al. (2019) & ASFV & $\begin{array}{l}\text { Semi- } \\
\text { quantitative }\end{array}$ & Soft ticks, domestic pigs, bushpigs, warthogs & $\begin{array}{l}\text { Ornithodoros coriaceus (highest risk soft tick in those } \\
\text { evaluated) }\end{array}$ \\
\hline Jurado et al. (2019) & ASFV & Quantitative & Swine products carried by air passengers & Not identified \\
\hline
\end{tabular}

\begin{tabular}{|c|c|c|c|c|}
\hline $\begin{array}{l}\text { Wormington } \\
\text { et al. (2019) }\end{array}$ & ASFV & Qualitative & Sylvatic establishment and spillover to domestic swine & Not identified \\
\hline $\begin{array}{l}\text { Blackwell } \\
\text { et al. (1985) }\end{array}$ & CSFV & Qualitative & $\begin{array}{l}\text { Feeding garbage to livestock, international trade of food } \\
\text { products of animal origin }\end{array}$ & Not identified \\
\hline Corso (1997) & CSFV & Quantitative & $\begin{array}{l}\text { Uncooked swill (due to legal/illegal importation of food items } \\
\text { of animal origin by way of traveller or by mail, which is then } \\
\text { discarded in household waste) }\end{array}$ & Uncooked contaminated swill feeding \\
\hline USDA (1998a) & CSFV & Qualitative & $\begin{array}{l}\text { Imported infected pork and/or pork products either discarded } \\
\text { as household waste and deposited in landfill or fed to } \\
\text { backyard pig herd }\end{array}$ & $\begin{array}{l}\text { Illegal importation of pork/pork products via airline } \\
\text { passengers }\end{array}$ \\
\hline USDA (1998b) & CSFV & Both & $\begin{array}{l}\text { Legal importation of fresh, chilled and frozen pork; import of } \\
\text { breeding animals (boars and gilts); and imports of fresh and } \\
\text { frozen semen }\end{array}$ & $\begin{array}{l}\text { Not explicitly stated; however data implies import of } \\
\text { breeding boars (very high cost scenario), import of } \\
\text { fresh, chilled and frozen pork (low cost scenario), } \\
\text { import of fresh and frozen semen (low, moderate high } \\
\text { and very high cost scenarios) }\end{array}$ \\
\hline
\end{tabular}




\begin{tabular}{|c|c|c|c|c|c|}
\hline $\begin{array}{l}\text { Assessed geographic } \\
\text { source }\end{array}$ & $\begin{array}{l}\text { Highest risk } \\
\text { geographic source }\end{array}$ & $\begin{array}{l}\text { Assessed } \\
\text { geographic } \\
\text { destination }\end{array}$ & $\begin{array}{l}\text { Highest risk geographic } \\
\text { destination }\end{array}$ & Highest risk consequence & Model \\
\hline Not identified & Not identified & United States & Not identified & Not identified & N/A \\
\hline Foreign countries & Not identified & United States & Puerto Rico & Not identified & $\begin{array}{l}\text { Scenario event trees with nesting } \\
\text { binomial probability formulas }\end{array}$ \\
\hline Not identified & Not identified & United States & Not identified & Not identified & $\begin{array}{l}\text { Nested binomial model and } \\
\text { Monte Carlo modelling }\end{array}$ \\
\hline Not identified & Not identified & United States & Not identified & Not identified & N/A \\
\hline
\end{tabular}

\begin{tabular}{|c|c|c|c|c|c|}
\hline Not identified & Not identified & United States & Not identified & Not identified & $\mathrm{N} / \mathrm{A}$ \\
\hline Worldwide & $\begin{array}{l}\text { Canada (for live swine } \\
\text { pathway) }\end{array}$ & United States & $\begin{array}{l}\text { lowa, Minnesota and Wisconsin } \\
\text { (for live swine pathway) }\end{array}$ & Not identified & Stochastic \\
\hline $\begin{array}{l}\text { North America, Africa, } \\
\text { Asia, South America, } \\
\text { Australia, Europe }\end{array}$ & Africa, Asia, Europe & United States & Not identified & $\begin{array}{l}\text { Spread and persistence of } \\
\text { disease }\end{array}$ & $\mathrm{N} / \mathrm{A}$ \\
\hline $\begin{array}{l}\text { China (Trans-Pacific), and } \\
\text { the Caucasus, Eastern } \\
\text { Europe, the Baltic } \\
\text { states (Trans-Atlantic) }\end{array}$ & Not identified & United States & Not identified & Not identified & $\mathrm{N} / \mathrm{A}$ \\
\hline $\begin{array}{l}\text { Ornithodoros coriaceus } \\
\text { (highest risk soft tick in } \\
\text { those evaluated) }\end{array}$ & Not identified & United States & Not identified & Not identified & $\mathrm{N} / \mathrm{A}$ \\
\hline Foreign countries & $\begin{array}{l}\text { Ghana, Cape Verde, } \\
\text { Ethiopia, Russian } \\
\text { Federation }\end{array}$ & United States & $\begin{array}{l}\text { Main airports in Virginia, New } \\
\text { York, Texas, Rhode Island, } \\
\text { Puerto Rico }\end{array}$ & Not identified & $\begin{array}{l}\text { Quantitative stochastic models } \\
\text { for each disease }\end{array}$ \\
\hline Not identified & Not identified & United States & $\begin{array}{l}\text { Counties of California, Florida } \\
\text { and 'much of the South- } \\
\text { western United States' }\end{array}$ & Not identified & Spatial \\
\hline Not identified & Not identified & United States & Not identified & Not identified & $\mathrm{N} / \mathrm{A}$ \\
\hline Not identified & Not identified & United States & Not identified & Not Identified & $\begin{array}{l}\text { Nested binomial model and } \\
\text { Monte Carlo modelling }\end{array}$ \\
\hline Dominican Republic & Not identified & United States & Not identified & Not identified & $\mathrm{N} / \mathrm{A}$ \\
\hline European Union & Not identified & United States & Texas or Florida & $\begin{array}{l}\text { Import of infected } \\
\text { breeding boars (very high } \\
\text { cost scenario) }\end{array}$ & $\begin{array}{l}\text { Net Trade Model (Partial } \\
\text { Equilibrium Welfare Model also } \\
\text { mentioned as being used to } \\
\text { model impacts of disease on US) }\end{array}$ \\
\hline
\end{tabular}


TABLE A1 (Continued)

\begin{tabular}{|c|c|c|c|c|}
\hline Authors \& date & Pathogen & Type of study & Assessed pathways of introduction & Highest risk pathway of introduction \\
\hline USDA (1998c) & CSFV & Both & $\begin{array}{l}\text { Legal importation of fresh, chilled and frozen pork; import of } \\
\text { breeding animals (boars and gilts); and imports of fresh and } \\
\text { frozen semen }\end{array}$ & Not identified \\
\hline USDA (1998d) & CSFV & Both & Importation of pork & Not identified \\
\hline USDA (1999) & CSFV & Both & $\begin{array}{l}\text { Unmitigated importation of swine semen; fresh, chilled and } \\
\text { frozen pork (and subsequent feeding of food waste to pigs); } \\
\text { and breeding swine }\end{array}$ & $\begin{array}{l}\text { Not explicitly identified, although swine semen model } \\
\text { appeared to have the highest expected frequency } \\
\text { under unmitigated conditions (within the 'most likely' } \\
\text { output category) }\end{array}$ \\
\hline USDA (1998e) & CSFV & Both & $\begin{array}{l}\text { Unmitigated importation of swine semen; fresh, chilled and } \\
\text { frozen pork (and subsequent feeding of food waste to pigs); } \\
\text { and breeding swine }\end{array}$ & $\begin{array}{l}\text { Not explicitly identified, although swine semen model } \\
\text { appeared to have the highest expected frequency } \\
\text { under unmitigated conditions (within the 'most likely' } \\
\text { output category) }\end{array}$ \\
\hline $\begin{array}{l}\text { Dietrich and } \\
\text { Adams (2000) }\end{array}$ & CSFV & Quantitative & $\begin{array}{l}\text { Legal and illegal importation of food products via garbage or } \\
\text { waste feeding operations; contact of domestic swine with } \\
\text { feral hogs exposed through contaminated food dropped in } \\
\text { areas frequented by feral hogs }\end{array}$ & Not identified \\
\hline
\end{tabular}

\begin{tabular}{|c|c|c|c|c|}
\hline USDA (2000) & CSFV & Both & $\begin{array}{l}\text { Movement of domestic animals, transmission from wild boars, } \\
\text { distribution of contaminated swine semen, distribution of } \\
\text { fresh/frozen pork, and movement of contaminated people, } \\
\text { vehicles or equipment }\end{array}$ & Contaminated swine semen \\
\hline USDA (2002) & CSFV & Qualitative & Not identified & Not identified \\
\hline NABC (2004) & CSFV & Qualitative & $\begin{array}{l}\text { Live swine, hog products industry related products (e.g. } \\
\text { feed and farm equipment) and humans. Also discusses wild } \\
\text { boar and domestic swine direct/indirect contact; feeding } \\
\text { of unsanitized garbage to swine; javelina and pet pigs as } \\
\text { pathways/maintenance factors }\end{array}$ & Importation of infected swine products (legal and illegal) \\
\hline USDA (2014a) & CSFV & Qualitative & $\begin{array}{l}\text { Dietary supplements/traditional medicines, veterinary } \\
\text { vaccines and miscellaneous biological products, } \\
\text { unprocessed animal feed ingredients derived from plants } \\
\text { or plant products, commercial swine meat and meat (by) } \\
\text { products for human consumption, non-render }\end{array}$ & Diagnostic samples collected from swine or ruminants \\
\hline $\begin{array}{l}\text { Chen and Jiang } \\
\text { (2017) }\end{array}$ & CSFV & Qualitative & Animal waste in manure & Not identified \\
\hline $\begin{array}{c}\text { Herrera-Ibatá } \\
\text { et al. (2017) }\end{array}$ & CSFV & Quantitative & Legal importation of swine and swine products & Legal importation of live pigs \\
\hline Dee et al. (2018) & CSFV & Quantitative & Importation of feed ingredients & Not identified \\
\hline
\end{tabular}




\begin{tabular}{|c|c|c|c|c|c|}
\hline $\begin{array}{l}\text { Assessed geographic } \\
\text { source }\end{array}$ & $\begin{array}{l}\text { Highest risk } \\
\text { geographic source }\end{array}$ & $\begin{array}{l}\text { Assessed } \\
\text { geographic } \\
\text { destination }\end{array}$ & $\begin{array}{l}\text { Highest risk geographic } \\
\text { destination }\end{array}$ & Highest risk consequence & Model \\
\hline $\begin{array}{l}\text { Netherlands, Italy, Spain, } \\
\text { Belgium-Luxembourg, } \\
\text { Portugal, Germany, } \\
\text { Denmark, Austria, } \\
\text { France }\end{array}$ & Not identified & United States & Not identified & Not identified & Net Trade Model \\
\hline $\begin{array}{l}\text { European Union (with } \\
\text { specific attention } \\
\text { to Germany, the } \\
\text { Netherlands, Italy and } \\
\text { Spain) }\end{array}$ & Not identified & United States & Not identified & Not identified & N/A \\
\hline European Union & Not identified & United States & Not identified & Not identified & $\begin{array}{l}\text { Stochastic (nested probability } \\
\text { approach) }\end{array}$ \\
\hline European Union & Not identified & United States & Not identified & $\begin{array}{l}\text { Not explicitly identified, } \\
\text { although unmitigated } \\
\text { swine semen model } \\
\text { generated the lowest } \\
\text { NPV value (indicating the } \\
\text { costs associated with this } \\
\text { pathway are higher than } \\
\text { any benefits of trade) }\end{array}$ & $\begin{array}{l}\text { Stochastic (nested probability } \\
\text { approach) for Biological Risk } \\
\text { Analysis; economic values } \\
\text { determined through estimation, } \\
\text { not modelling }\end{array}$ \\
\hline Not identified & Not identified & $\begin{array}{l}\text { Southern United } \\
\text { States (Alabama, } \\
\text { Arkansas, } \\
\text { Florida, Georgia, } \\
\text { Louisiana, } \\
\text { Mississippi, } \\
\text { North Carolina, } \\
\text { South Carolina, } \\
\text { Tennessee, Texas) }\end{array}$ & Not identified & $\begin{array}{l}\text { Scenario } 2 \text {; introduction } \\
\text { of CSFV into } 3 \\
\text { geographically separated } \\
\text { regions }\end{array}$ & $\begin{array}{l}\text { Agricultural Sector Model (linear } \\
\text { programming model) }\end{array}$ \\
\hline European Union & Not identified & United States & Not identified & Not identified & Multi-level binomial \\
\hline Not identified & Dominican Republic & United States & Puerto Rico & Not identified & N/A \\
\hline Worldwide & $\begin{array}{l}\text { United Kingdom (for } \\
\text { live swine); United } \\
\text { Kingdom, Germany, } \\
\text { Italy (for pig meat); } \\
\text { Dominican Republic } \\
\text { and the Caribbean } \\
\text { (for illegal pigs/pig } \\
\text { products) }\end{array}$ & United States & $\begin{array}{l}\text { Puerto Rico, South-eastern } \\
\text { United States (for illegal } \\
\text { movement of pigs and pig } \\
\text { products) }\end{array}$ & Texas & $\begin{array}{l}\text { Trading grid (to describe } \\
\text { movement of live swine and } \\
\text { swine products and relate to the } \\
\text { occurrence of CSFV worldwide); } \\
\text { also survey of experts and swine } \\
\text { producers }\end{array}$ \\
\hline Not identified & Not identified & United States & Not identified & Not identified & N/A \\
\hline
\end{tabular}

\begin{tabular}{|c|c|c|c|c|c|}
\hline Not identified & Not identified & United States & Not identified & Not identified & $\mathrm{N} / \mathrm{A}$ \\
\hline Worldwide & $\begin{array}{l}\text { Canada (for live swine } \\
\text { pathway) }\end{array}$ & United States & $\begin{array}{l}\text { lowa, Minnesota and Wisconsin } \\
\text { (for live swine pathway) }\end{array}$ & Not identified & Stochastic \\
\hline $\begin{array}{l}\text { China (Trans-Pacific), and } \\
\text { the Caucasus, Eastern } \\
\text { Europe, the Baltic } \\
\text { states (Trans-Atlantic) }\end{array}$ & Not identified & United States & Not identified & Not identified & $\mathrm{N} / \mathrm{A}$ \\
\hline
\end{tabular}


TABLE A1 (Continued)

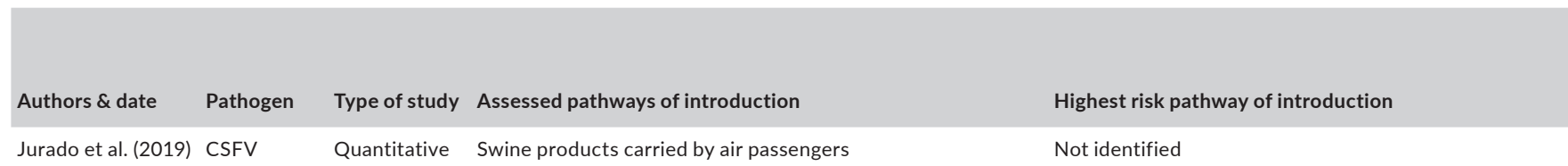

\begin{tabular}{|c|c|c|c|c|}
\hline $\begin{array}{l}\text { Blackwell } \\
\text { et al. (1985) }\end{array}$ & FMDV & Qualitative & $\begin{array}{l}\text { Feeding garbage to livestock, international trade of food } \\
\text { products of animal origin }\end{array}$ & Not identified \\
\hline USDA (1994) & FMDV & Qualitative & $\begin{array}{l}\text { Import of infected live animals, contaminated animal products } \\
\text { and fomites }\end{array}$ & Not identified \\
\hline USDA (1995) & FMDV & Quantitative & $\begin{array}{l}\text { Feeding household waste contaminated by contraband or } \\
\text { legal imports to domestic swine }\end{array}$ & $\begin{array}{l}\text { Contraband contaminated household waste being fed to } \\
\text { domestic swine }\end{array}$ \\
\hline Corso (1997) & FMDV & Quantitative & $\begin{array}{l}\text { Uncooked swill (due to legal/illegal importation of food items } \\
\text { of animal origin by way of traveller or by mail, which is then } \\
\text { discarded in household waste) }\end{array}$ & Uncooked contaminated swill feeding \\
\hline
\end{tabular}

\begin{tabular}{|c|c|c|c|c|}
\hline CEAH (2001) & FMDV & Qualitative & $\begin{array}{l}\text { Contraband, illegal trans-shipments, garbage, animal } \\
\text { products, human movements from foreign countries, live } \\
\text { animals, animal germplasm, military movements }\end{array}$ & $\begin{array}{l}\text { Contraband (meat products carried by passengers/in } \\
\text { cargo containers/sent by mail/FedEx, black market) }\end{array}$ \\
\hline $\begin{array}{l}\text { Federal Inter- } \\
\text { agency Working }\end{array}$ & FMDV & Qualitative & $\begin{array}{l}\text { Importation of infected animals or contaminated animal } \\
\text { products }\end{array}$ & $\begin{array}{l}\text { Contraband from international passengers, cargo, mail } \\
\text { and vehicles }\end{array}$ \\
\hline
\end{tabular}

Group (2003)

Breeze (2004) FMDV Qualitative Agroterrorism Not identified

USDA (2007) FMDV Qualitative Meat, meat products or garbage feeding pathways; livestock importations

Not identified; results of this analysis reported the hazard ranking (low, moderate or high) of potential sources including animals, animal products and fomites. Of 99 animals identified as possible FMDV sources, 31 categorized as high hazards (Antelope, African buffalo, domestic cattle, mountain gazelle, impala, goat, sheep, alpaca, Bactrian camel, llama, fallow deer, mule deer, muntjac deer, red deer, roe deer, sika deer, white-tailed deer, domestic pig, fox human, capybara, coypu, rat, grey kangaroo, red kangaroo, tree kangaroo, hedgehog, starling, house fly, biting fly, tick). Of 97 animal products/other fomites identified, 53 categorized as high hazards (hides/skins, bovine manure, bovine pituitary extract, bovine semen, sheep wool, bacon, whole beef, bovine blood, bovine bone marrow, porcine bone marrow, cultured butter, buttermilk, bovine dried casein, ham, sheep intestinal casings, swine intestinal casings, bovine lymph node, porcine lymph node, bovine milk, pork muscle, bovine rumen, dry sausage, bovine tongue. *See tables for details on product processing). Of 15 non-food products identified, 12 were categorized as high hazard (straw/wood shaving bedding, clothing, feed and fodder, garbage, packing/ wrapping materials, shoes/boots, autumn/winter soil, vegetables, water)

\begin{tabular}{|c|c|c|c|c|}
\hline USDA (2012) & FMDV & Qualitative & $\begin{array}{l}\text { Legal and illegal import of contaminated products, fomites, } \\
\text { infected animals or animal products }\end{array}$ & Legal and illegal imports \\
\hline USDA (2013) & FMDV & Qualitative & Importation of beef products & Feeding contaminated food waste to swine \\
\hline $\begin{array}{l}\text { Slingluff } \\
\text { et al. (2014) }\end{array}$ & FMDV & Both & $\begin{array}{l}\text { Movement of infected carcasses (swine and cattle) during an } \\
\text { outbreak }\end{array}$ & Not identified \\
\hline USDA (2014a) & FMDV & Qualitative & $\begin{array}{l}\text { Import of infected live animals, infected embryos and semen, } \\
\text { and contaminated sheep meat }\end{array}$ & Not identified \\
\hline
\end{tabular}




\begin{tabular}{|c|c|c|c|c|c|}
\hline $\begin{array}{l}\text { Assessed geographic } \\
\text { source }\end{array}$ & $\begin{array}{l}\text { Highest risk } \\
\text { geographic source }\end{array}$ & $\begin{array}{l}\text { Assessed } \\
\text { geographic } \\
\text { destination }\end{array}$ & $\begin{array}{l}\text { Highest risk geographic } \\
\text { destination }\end{array}$ & Highest risk consequence & Model \\
\hline Foreign countries & $\begin{array}{c}\text { Dominican Republic, } \\
\text { followed by Cuba }\end{array}$ & United States & $\begin{array}{l}\text { Main airports in Puerto Rico, } \\
\text { Florida, North Carolina, New } \\
\text { Jersey, Ohio }\end{array}$ & Not identified & $\begin{array}{l}\text { Quantitative stochastic models } \\
\text { for each disease }\end{array}$ \\
\hline Not identified & Not identified & United States & Not identified & Not identified & N/A \\
\hline $\begin{array}{l}\text { Countries with past } \\
\text { outbreaks }\end{array}$ & Not identified & North America & Not identified & Not identified & N/A \\
\hline Foreign countries & Not identified & United States & Puerto Rico & Not identified & $\begin{array}{l}\text { Scenario event trees with nesting } \\
\text { binomial probability formulas }\end{array}$ \\
\hline Not identified & Not identified & United States & Not identified & Not identified & $\begin{array}{l}\text { Nested binomial model and } \\
\text { Monte Carlo modelling }\end{array}$ \\
\hline Worldwide & Not identified & United States & $\begin{array}{l}\text { United States swine waste } \\
\text { feeding operations (Puerto } \\
\text { Rico and the Virgin Islands } \\
\text { have the most) }\end{array}$ & Not identified & N/A \\
\hline Not identified & Not identified & United States & $\begin{array}{l}\text { Areas most densely populated } \\
\text { with livestock in the United } \\
\text { States (see map } 2 \text { page } 10 \text { ) }\end{array}$ & Not identified & N/A \\
\hline Worldwide & Not identified & United States & $\begin{array}{l}\text { Midwest (for swine); Midwest } \\
\text { and Southwest states (for } \\
\text { feedlot cattle) }\end{array}$ & Not identified & $\mathrm{N} / \mathrm{A}$ \\
\hline $\begin{array}{l}\text { Countries with past } \\
\text { outbreaks }\end{array}$ & Not identified & North America & Not identified & Not identified & N/A \\
\hline
\end{tabular}

$\begin{array}{lllll}\begin{array}{l}\text { Infected countries, } \\ \text { Canada and Mexico }\end{array} & \text { Not identified } & \text { United States } & \text { Texas } & \text { Not identified } \\ \text { Brazil } & \text { Not identified } & \text { United States } & \text { Not identified } & \text { Not identified } \\ \text { United States } & \text { Not identified } & \text { United States } & \text { Not identified } & \text { Not identified } \\ \text { Argentina } & \text { Not identified } & \text { United States } & \text { Not identified } & \text { Within herd stochastic disease } \\ \text { spread model } & \text { N/A identified }\end{array}$


TABLE A1 (Continued)

\begin{tabular}{|c|c|c|c|c|}
\hline Authors \& date & Pathogen & Type of study & Assessed pathways of introduction & Highest risk pathway of introduction \\
\hline USDA (2014b) & FMDV & Qualitative & $\begin{array}{l}\text { Dietary supplements/traditional medicines, veterinary } \\
\text { vaccines and miscellaneous biological products, } \\
\text { unprocessed animal feed ingredients derived from plants } \\
\text { or plant products, commercial swine meat and meat (by) } \\
\text { products for human consumption, non-render }\end{array}$ & Diagnostic samples collected from swine or ruminants \\
\hline USDA (2018) & FMDV & Both & Feeding livestock contaminated ready-to-eat pork products & Not identified \\
\hline $\begin{array}{l}\text { Chen and Jiang } \\
\text { (2017) }\end{array}$ & FMDV & Qualitative & Animal waste in manure & Not identified \\
\hline Dee et al. (2018) & FMDV & Quantitative & Importation of feed ingredients & Not identified \\
\hline
\end{tabular}

\begin{tabular}{|c|c|c|c|c|}
\hline $\begin{array}{l}\text { Bair-Brake } \\
\text { et al. (2014) }\end{array}$ & $\begin{array}{l}\text { Not } \\
\text { identified }\end{array}$ & Both & Bushmeat importation & Not identified \\
\hline \multicolumn{5}{|l|}{ Foreign assessments } \\
\hline MacDiarmid (1991) & ASFV & Qualitative & Importation of meat and meat products & Not identified \\
\hline CFIA (1999) & ASFV & Both & $\begin{array}{l}\text { Salted intestinal casings fed to domestic pigs (legally or } \\
\text { illegally imported) }\end{array}$ & Salted intestinal casings fed to wild pigs \\
\hline Adkin et al. (2004) & ASFV & Quantitative & $\begin{array}{l}\text { Illegally imported meat and meat products and imported } \\
\text { catering waste (e.g. ship and aircraft waste) }\end{array}$ & $\begin{array}{l}\text { Imports of de-boned meat via air-passenger baggage } \\
\text { most likely to cause subsequent livestock infection } \\
\text { after being introduced }\end{array}$ \\
\hline Gale (2004) & ASFV & Quantitative & $\begin{array}{l}\text { Composted catering waste containing uncooked meat } \\
\text { discarded on farm land or fed to animals }\end{array}$ & $\begin{array}{l}\text { Composted uncooked animal waste being fed to farm } \\
\text { animals or distributed near them }\end{array}$ \\
\hline
\end{tabular}

\begin{tabular}{llll}
$\begin{array}{l}\text { Wooldridge } \\
\text { et al. (2006) }\end{array}$ & ASFV & Quantitative & $\begin{array}{c}\text { De-boned meat, and meat that follows human carriage (litter, Illegal importation of meat by way of passenger baggage } \\
\text { 'fly-tipping', direct feeding) }\end{array}$ \\
\hline $\begin{array}{l}\text { Sánchez-Vizcaíno } \\
\text { ASFV }\end{array}$ & Qualitative & $\begin{array}{c}\text { Tick bites and movement of infected pigs } \\
\text { Tree-ranging pigs }\end{array}$
\end{tabular}

\begin{tabular}{|c|c|c|c|c|}
\hline DEFRA (2008) & ASFV & Qualitative & Import of animal products & Not identified \\
\hline $\begin{array}{l}\text { Beltrán-Alcrudo } \\
\text { et al. (2008) }\end{array}$ & ASFV & Qualitative & $\begin{array}{l}\text { Wild boar, vectors (e.g. ticks), pork and pork products } \\
\text { imported and swill feed to domestic swine or accessed by } \\
\text { wild boar }\end{array}$ & Not identified \\
\hline
\end{tabular}

$\begin{array}{lllll}\begin{array}{l}\text { Costard } \\ \text { et al. (2009) }\end{array} & \text { ASFV } & \text { Quantitative } & \text { Animal-contact, person- and vehicle-contact, feeding } & \text { Not identified } \\ \text { Hartley (2010) } & \text { ASFV } & \text { Qualitative } & \begin{array}{c}\text { Legal/illegal importation of pig products, direct and indirect } \\ \text { contact between feral swine and livestock (airborne, faeco- }\end{array} \text { Oral consumption of illegally imported pig products by } \\ & & \text { doms }\end{array}$
oral, food borne, vector borne), import or translocation of feral swine 


\begin{tabular}{|c|c|c|c|c|c|}
\hline $\begin{array}{l}\text { Assessed geographic } \\
\text { source }\end{array}$ & $\begin{array}{l}\text { Highest risk } \\
\text { geographic source }\end{array}$ & $\begin{array}{l}\text { Assessed } \\
\text { geographic } \\
\text { destination }\end{array}$ & $\begin{array}{l}\text { Highest risk geographic } \\
\text { destination }\end{array}$ & Highest risk consequence & Model \\
\hline Not identified & Not identified & United States & Not identified & Not identified & $\mathrm{N} / \mathrm{A}$ \\
\hline United States & Not identified & United States & Not identified & Not identified & $\begin{array}{l}\text { Within herd stochastic disease } \\
\text { spread model }\end{array}$ \\
\hline Not identified & Not identified & United States & Not identified & Not identified & $\mathrm{N} / \mathrm{A}$ \\
\hline $\begin{array}{l}\text { China (Trans-Pacific), and } \\
\text { the Caucasus, Eastern } \\
\text { Europe, the Baltic } \\
\text { states (Trans-Atlantic) }\end{array}$ & Not identified & United States & Not identified & Not identified & $\mathrm{N} / \mathrm{A}$ \\
\hline Not identified & West Africa & United States & Not identified & Not Identified & $\mathrm{N} / \mathrm{A}$ \\
\hline Not identified & Not identified & New Zealand & Not identified & Not identified & $\mathrm{N} / \mathrm{A}$ \\
\hline Not identified & Not identified & Canada & Not identified & Not identified & $\mathrm{N} / \mathrm{A}$ \\
\hline Non-EU countries & Eastern Africa & Great Britain & Not identified & Not identified & Stochastic \\
\hline United Kingdom & Not identified & United Kingdom & Not identified & $\begin{array}{l}\text { Multiple farm animals } \\
\text { eating bits of the same } \\
\text { contaminated waste, } \\
\text { rather than one single } \\
\text { pig eating all of the } \\
\text { contaminated portion of } \\
\text { waste }\end{array}$ & $\begin{array}{l}\text { Source-pathway-receptor } \\
\text { approach }\end{array}$ \\
\hline Worldwide & Eastern Africa & Great Britain & Not identified & Not identified & Common structure model \\
\hline Europe and Africa & Not identified & Europe and Africa & Not identified & Not identified & $\begin{array}{l}\text { This document is more of a } \\
\text { scientific and pathobiology } \\
\text { review rather than a risk } \\
\text { assessment. It states that the } \\
\text { exponential intensification of } \\
\text { animal movements and product } \\
\text { exchanges enhances the risk } \\
\text { of ASFV introduction in a free } \\
\text { country }\end{array}$ \\
\hline Non-EU countries & Not identified & Great Britain & Not identified & Not identified & $\mathrm{N} / \mathrm{A}$ \\
\hline Caucasus region & Not identified & $\begin{array}{l}\text { Turkey, Iran, } \\
\text { Russian } \\
\text { Federation, } \\
\text { Ukraine }\end{array}$ & Russian Federation and Ukraine & Not identified & $\mathrm{N} / \mathrm{A}$ \\
\hline Not identified & Not identified & Madagascar & Not identified & Not identified & $\begin{array}{l}\text { Multiple factor analysis and } \\
\text { hierarchical cluster analysis }\end{array}$ \\
\hline Not identified & Not identified & England & Not identified & $\begin{array}{l}\text { Introduction into wild boar } \\
\text { population/spread and } \\
\text { duration of the disease }\end{array}$ & $\mathrm{N} / \mathrm{A}$ \\
\hline
\end{tabular}


TABLE A1 (Continued)

\begin{tabular}{|c|c|c|c|c|}
\hline Authors \& date & Pathogen & Type of study & Assessed pathways of introduction & Highest risk pathway of introduction \\
\hline $\begin{array}{l}\text { Wieland } \\
\text { et al. (2011) }\end{array}$ & ASFV & Qualitative & $\begin{array}{l}\text { Domestic pigs: direct contact between pigs, indirect } \\
\text { contact between pork products and pigs, contaminated } \\
\text { feed, fomites, mechanical vectors (pets and pests), ticks, } \\
\text { contamination of environment which spills over in wild } \\
\text { boar and tick population. Wild Boar: direct contact, indirect } \\
\text { contact through hunting or contaminated environment }\end{array}$ & Not identified \\
\hline $\begin{array}{l}\text { Mur, Martínez- } \\
\text { López, } \\
\text { Martínez-Avilés, } \\
\text { et al. (2012) }\end{array}$ & ASFV & Quantitative & $\begin{array}{l}\text { Importation of an ASF-infected (but non-detected) pig during } \\
\text { the high risk period, subsequent contact with susceptible pig }\end{array}$ & Importation of infected live pigs \\
\hline Mur et al. (2012) & ASFV & $\begin{array}{l}\text { Semi- } \\
\text { quantitative }\end{array}$ & $\begin{array}{l}\text { Returning livestock trucks from affected areas, waste from } \\
\text { international ships and waste from international planes }\end{array}$ & Returning livestock vehicles (trucks) \\
\hline Nigsch et al. (2013) & ASFV & Both & Pig to pig contact; pig transport lorries; professional contacts & Not identified \\
\hline $\begin{array}{l}\text { Costard } \\
\text { et al. (2013) }\end{array}$ & ASFV & $\begin{array}{l}\text { Semi- } \\
\text { quantitative }\end{array}$ & $\begin{array}{l}\text { Illegal importation of pork and pork products via personal } \\
\text { consumption purposes and commercial/re-sale purposes }\end{array}$ & $\begin{array}{l}\text { Illegal importation by EU residents originally from ASFV } \\
\text { affected areas }\end{array}$ \\
\hline $\begin{array}{l}\text { Cardoso de } \\
\text { Carvalho Ferreira } \\
\text { (2013) }\end{array}$ & ASFV & Qualitative & $\begin{array}{l}\text { Transmission between individuals within the same group, } \\
\text { between different groups/individuals on different farms, } \\
\text { and via tick vectors }\end{array}$ & Not identified \\
\hline Mur et al. (2014) & ASFV & Both & $\begin{array}{l}\text { Legal importations of pigs, legal/illegal imports of products, } \\
\text { transportation fomites (including contaminated trucks or } \\
\text { waste from international planes and ships) and wild boar } \\
\text { movements }\end{array}$ & $\begin{array}{l}\text { Highest risk route depended on pathway and EU } \\
\text { member-state. Bulgaria highest risk for legally importec } \\
\text { products during the high risk period; Finland highest } \\
\text { risk for wild boar movement route; Slovenia and } \\
\text { Sweden for legally imported pigs during the high risk } \\
\text { period }\end{array}$ \\
\hline $\begin{array}{l}\text { EFSA Panel on } \\
\text { Animal Health } \\
\text { and Welfare } \\
\text { (2014) }\end{array}$ & ASFV & Qualitative & $\begin{array}{l}\text { Movement of contaminated pork, movement of infected pigs, } \\
\text { movement of contaminated vehicles }\end{array}$ & $\begin{array}{l}\text { Chilled meat; transported wild boar; transported } \\
\text { domestic swine; skin fat; vehicles for animal transport- } \\
\text { contaminated inside }\end{array}$ \\
\hline $\begin{array}{l}\text { Roelandt } \\
\text { et al. (2017) }\end{array}$ & ASFV & $\begin{array}{l}\text { Semi- } \\
\text { quantitative }\end{array}$ & Not identified & Not identified \\
\hline $\begin{array}{l}\text { Martínez-López } \\
\text { et al. (2015) }\end{array}$ & ASFV & Quantitative & Not identified & Not identified \\
\hline Torre et al. (2015) & ASFV & $\begin{array}{l}\text { Semi- } \\
\text { quantitative }\end{array}$ & $\begin{array}{l}\text { Infected wild boars; contact with uninfected swine (wild and } \\
\text { domestic) }\end{array}$ & Not identified \\
\hline Bellini et al. (2016) & ASFV & Qualitative & $\begin{array}{l}\text { Direct pig-to-pig contact, contaminated feed (swill feeding), } \\
\text { workers visitors, contaminated fomites, slurry, genetic } \\
\text { materials and tick bites }\end{array}$ & Not identified \\
\hline Dejyong (2016) & ASFV & Qualitative & $\begin{array}{l}\text { Legal and illegal import of live pigs, pig products, pig semen } \\
\text { and embryos, wild boars, wild boar meat, biological } \\
\text { products, potbellied pigs and personal items }\end{array}$ & $\begin{array}{l}\text { Shipment of pig products (frozen meat considered very } \\
\text { high risk) }\end{array}$ \\
\hline CFSPH (2016) & ASFV & Quantitative & $\begin{array}{l}\text { Feeding of food waste from international airplanes or } \\
\text { ships from countries where disease is found, feral swine } \\
\text { movements, movement of trucks between infected and } \\
\text { disease-free areas, illegal movement of infected pigs or pork } \\
\text { products }\end{array}$ & Not identified \\
\hline $\begin{array}{l}\text { Halasa, Boklund, } \\
\text { et al. (2016)), } \\
\text { Halasa, Bøtner, } \\
\text { et al. (2016)) }\end{array}$ & ASFV & Quantitative & $\begin{array}{l}\text { Dead animal (pig) residues: (blood, liquids and faeces), and } \\
\text { contact between pigs }\end{array}$ & Not identified \\
\hline
\end{tabular}




\begin{tabular}{|c|c|c|c|c|c|}
\hline $\begin{array}{l}\text { Assessed geographic } \\
\text { source }\end{array}$ & $\begin{array}{l}\text { Highest risk } \\
\text { geographic source }\end{array}$ & $\begin{array}{l}\text { Assessed } \\
\text { geographic } \\
\text { destination }\end{array}$ & $\begin{array}{l}\text { Highest risk geographic } \\
\text { destination }\end{array}$ & Highest risk consequence & Model \\
\hline Not identified & Not identified & European Union & $\begin{array}{l}\text { Germany, Northern France, } \\
\text { Central Italy (places with high } \\
\text { feral swine populations) }\end{array}$ & Not identified & Generic model \\
\hline $\begin{array}{l}\text { Albania, Canada, } \\
\text { Switzerland, Norway, } \\
\text { Russian Federation, } \\
\text { United States, Australia, } \\
\text { Belarus }\end{array}$ & Russian Federation & European Union & Poland & Not identified & $\begin{array}{l}\text { Stochastic. Parameters } \\
\text { individually defined using } \\
\text { various distributions (beta, pert, } \\
\text { normal and binomial) }\end{array}$ \\
\hline $\begin{array}{l}\text { Russian Federation, } \\
\text { Africa }\end{array}$ & Not identified & European Union & Poland, Lithuania & Not identified & Linear-weighted \\
\hline European Union & $\begin{array}{l}\text { Denmark, Netherlands, } \\
\text { Lithuania, Latvia }\end{array}$ & European Union & Germany and Poland & Not identified & $\begin{array}{l}\text { Stochastic spatio-temporal state- } \\
\text { transition model }\end{array}$ \\
\hline Not identified & Not identified & European Union & $\begin{array}{l}\text { France, Germany, Italy, United } \\
\text { Kingdom (high risk for release) }\end{array}$ & $\begin{array}{l}\text { Spread of the disease: } \\
\text { France, Italy, Poland, } \\
\text { Romania and Spain at } \\
\text { highest risk for exposure } \\
\text { after virus release }\end{array}$ & Linear-weighted combination \\
\hline Not identified & Not identified & Not identified & Not identified & Not identified & Descriptive \\
\hline Not identified & Not identified & European Union & $\begin{array}{l}\text { Bulgaria- for legally imported } \\
\text { products, Finland- for wild } \\
\text { boar, Slovenia \& Sweden- } \\
\text { legally imported pigs }\end{array}$ & Not identified & $\begin{array}{l}\text { Modular risk assessment } \\
\text { framework }\end{array}$ \\
\hline $\begin{array}{l}\text { Countries neighbouring } \\
\text { the European Union }\end{array}$ & $\begin{array}{l}\text { Georgia, Armenia } \\
\text { and the Russian } \\
\text { Federation }\end{array}$ & European Union & Not identified & Not identified & Expert elicitation/matrix model \\
\hline Not identified & Not identified & Belgium & Not identified & $\begin{array}{l}\text { Introduction and spread in } \\
\text { domestic animals }\end{array}$ & Pandora risk assessment tool \\
\hline Not identified & Not identified & Sardinia & Not identified & Not identified & Bayesian \\
\hline $\begin{array}{l}\text { Russia, Belarus, Ukraine, } \\
\text { Moldova and Turkey }\end{array}$ & Ukraine, Russia, Turkey & European Union & Finland, Romania, Latvia, Poland & Not identified & Stochastic \\
\hline Not identified & Not identified & Europe & Not identified & Not identified & $\mathrm{N} / \mathrm{A}$ \\
\hline Italy & Italy & Thailand & Thailand & Not identified & $\mathrm{N} / \mathrm{A}$ \\
\hline Not identified & Not identified & Not identified & Not identified & Not identified & $N / A$ \\
\hline
\end{tabular}

\begin{tabular}{|c|c|c|c|c|c|}
\hline Not identified & Not identified & Not identified & Not identified & $\begin{array}{l}\text { Sustained infectiousness } \\
\text { and disease spread }\end{array}$ & $\begin{array}{l}\text { Dynamic Monte Carlo simulation } \\
\text { model }\end{array}$ \\
\hline
\end{tabular}


TABLE A1 (Continued)

\begin{tabular}{|c|c|c|c|c|}
\hline Authors \& date & Pathogen & Type of study & Assessed pathways of introduction & Highest risk pathway of introduction \\
\hline Guinat et al. (2016) & ASFV & Qualitative & $\begin{array}{l}\text { Direct contact between infected and uninfected domestic } \\
\text { pigs, feeding domestic pigs contaminated feed, direct } \\
\text { contact between wild boar and domestic pigs, contaminated } \\
\text { fomites, ticks }\end{array}$ & Not identified \\
\hline Dione et al. (2016) & ASFV & Qualitative & $\begin{array}{l}\text { Collection/bulking (live pig traders and brokers); } \\
\text { Transportation (live pig traders and transporters of pig } \\
\text { meat/materials); Slaughter (Backyard slaughters, authorized } \\
\text { slaughter slabs and the Wambizzi abattoir) }\end{array}$ & Live pig traders and transport of pig meat/materials \\
\hline Huang et al. (2017) & ASFV & Quantitative & $\begin{array}{l}\text { Transmission by direct contact between humans, domestic } \\
\text { pigs, wild suids and ticks }\end{array}$ & $\begin{array}{l}\text { West Africa- direct contact between domestic pigs or } \\
\text { pork products and pigs; East Africa- not identified }\end{array}$ \\
\hline Hwang et al. (2018) & ASFV & $\begin{array}{l}\text { Semi- } \\
\text { quantitative }\end{array}$ & $\begin{array}{l}\text { Migration or natural movement of wildlife, International } \\
\text { human movement, Illegal importation of wildlife and } \\
\text { wildlife parts, Accidental introduction of disease vector, } \\
\text { Smuggling of livestock products, legal importation of } \\
\text { wildlife and wildlife parts, Legal importation of livestock and } \\
\text { products, Importation of biological materials and pathogens, } \\
\text { Importation of vegetables and plant material, Bioterrorism } \\
\text { or the deliberate release of pathogens }\end{array}$ & $\begin{array}{l}\text { Migration or natural movement of wildlife, illegal } \\
\text { importation of wildlife and wildlife parts, accidental } \\
\text { introduction of a disease vector, smuggling of livestock } \\
\text { products }\end{array}$ \\
\hline Kyyrö et al. (2017) & ASFV & $\begin{array}{l}\text { Semi- } \\
\text { quantitative }\end{array}$ & $\begin{array}{l}\text { Sperm and embryos; contaminated feed and bedding } \\
\text { materials; contaminated animal transport vehicles operating } \\
\text { internationally; infected wild animals crossing the border; } \\
\text { movements of other contaminated goods and transport; } \\
\text { infected live animals; air stream and/or vectors; infected } \\
\text { meat and meat products; and people travelling from } \\
\text { diseased areas }\end{array}$ & Products of animal origin (e.g. meat and meat products) \\
\hline Bosch et al. (2017) & ASFV & $\begin{array}{l}\text { Semi- } \\
\text { quantitative }\end{array}$ & Wild boar & Not identified \\
\hline $\begin{array}{l}\text { Bosch, Rodríguez, } \\
\text { et al. (2017) }\end{array}$ & ASFV & $\begin{array}{l}\text { Semi- } \\
\text { quantitative }\end{array}$ & $\begin{array}{l}\text { Infected wild boars coming into contact with uninfected wild } \\
\text { or domestic swine }\end{array}$ & $\begin{array}{l}\text { Natural movements of wild boar; domestic pig to } \\
\text { wild boar introduction; freshly harvested grass from } \\
\text { infected areas to low biosecurity farms }\end{array}$ \\
\hline
\end{tabular}

$\begin{array}{lll}\text { Anonymous (2017) } & \text { ASFV } & \text { Qualitative } \\ & \\ \text { DEFRA (2018) } & \text { ASFV } & \text { Qualitative }\end{array}$

Movement of infected live animals, infected products or contaminated equipment, vehicles, clothing and footwear, subsequent contact with domestic or feral swine (including wild boar)

Legal/illegal trade of live animals, products of animal origin, clothing/footwear, boats, vehicles, crops seeds and feeds, resulting in subsequent exposure to domestic or feral pigs

Contaminated clothing, footwear, equipment and vehicles; illegal movement of contaminated meat

Illegal trade of products of animal origin, vehicles

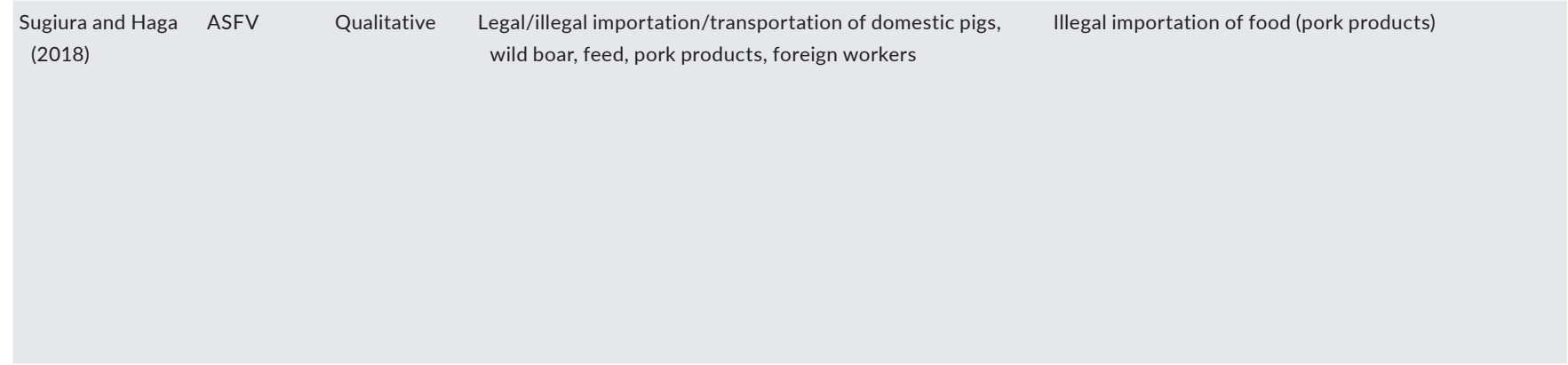




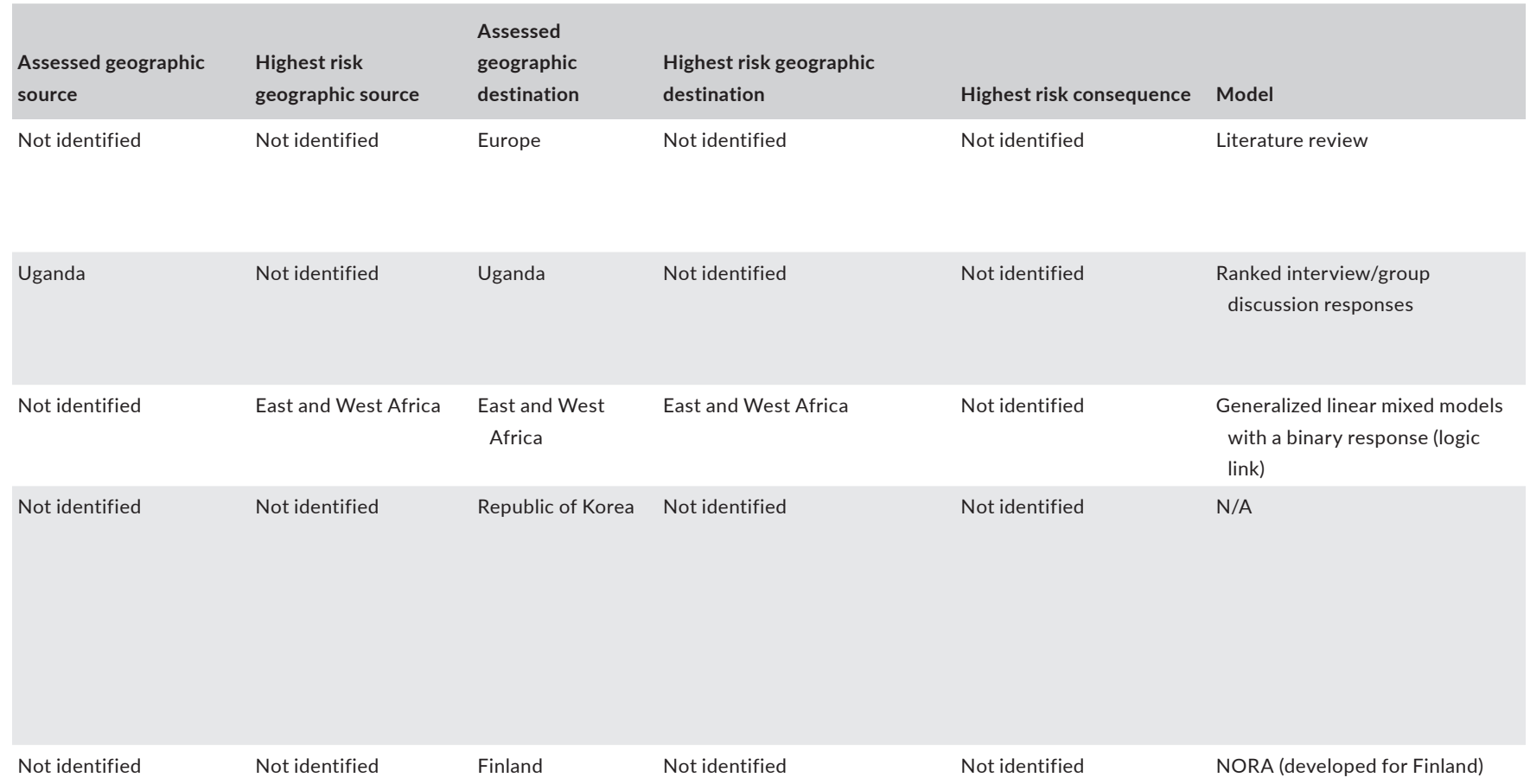

\begin{tabular}{|c|c|c|c|c|c|}
\hline Not identified & Not identified & Eurasia & Not identified & Not identified & Cartographic \\
\hline $\begin{array}{l}\text { Belarus, Estonia, Latvia, } \\
\text { Lithuania, Moldova, } \\
\text { Poland, Russia, Turkey, } \\
\text { Ukraine }\end{array}$ & $\begin{array}{l}\text { Russian Federation and } \\
\text { Ukraine, Lithuania, } \\
\text { Poland, Latvia, } \\
\text { Estonia }\end{array}$ & $\begin{array}{l}\text { Disease-free } \\
\text { European } \\
\text { Union countries } \\
\text { (Bulgaria, Czech } \\
\text { Republic, Finland, } \\
\text { Germany, Greece } \\
\text { Hungary, Romania } \\
\text { and Slovakia) }\end{array}$ & $\begin{array}{l}\text { Slovakia, Romania, Finland, } \\
\text { Czech Republic, Germany }\end{array}$ & Not identified & Stochastic \\
\hline Not identified & Not identified & European Union & Not identified & Not identified & $\mathrm{N} / \mathrm{A}$ \\
\hline Not identified & Not identified & Europe & Not identified & $\begin{array}{l}\text { Economic impact, as well } \\
\text { as effect on community } \\
\text { cohesion and animal } \\
\text { welfare; loss of public } \\
\text { confidence in pig industry }\end{array}$ & $\begin{array}{l}\text { OIE framework of release } \\
\text { (or entry), exposure and } \\
\text { consequence assessment }\end{array}$ \\
\hline $\begin{array}{l}\text { Africa (Burundi, Cape } \\
\text { Verde, Kenya, Mali, } \\
\text { South Africa, Uganda } \\
\text { Zimbabwe), Caucasus } \\
\text { (Moldova), East Europe } \\
\text { (Estonia, Latvia, } \\
\text { Lithuania, Poland } \\
\text { Ukraine), Russian } \\
\text { Federation, West } \\
\text { Europe (Italy-Sardinia), } \\
\text { East Asia (China) }\end{array}$ & China & Japan & Kanto and Kyushu & $\begin{array}{l}\text { Spread and persistence of } \\
\text { disease }\end{array}$ & Survey of experts' opinions \\
\hline
\end{tabular}


TABLE A1 (Continued)

\begin{tabular}{|c|c|c|c|c|}
\hline Authors \& date & Pathogen & Type of study & Assessed pathways of introduction & Highest risk pathway of introduction \\
\hline Jarvis (2018) & ASFV & Qualitative & $\begin{array}{l}\text { Swill feeding and long-distance transport of pigs, along with } \\
\text { the use of spray-dried porcine plasma in feed }\end{array}$ & Importation of swine, pork products and feed \\
\hline Middlemiss (2018) & ASFV & Qualitative & $\begin{array}{l}\text { Movement of infected meat, meat products resulting } \\
\text { in consumption by domestic swine or movement of } \\
\text { contaminated equipment/materials }\end{array}$ & Personal import of meat products \\
\hline $\begin{array}{l}\text { Fekede } \\
\text { et al. (2019) }\end{array}$ & ASFV & $\begin{array}{l}\text { Semi- } \\
\text { quantitative }\end{array}$ & Infected wild boar contacting uninfected domestic swine & Infected wild boar \\
\hline DEFRA (2017) & ASFV & Qualitative & $\begin{array}{l}\text { Legal and Illegal trade of live animals or animal products, } \\
\text { contaminated fomites }\end{array}$ & $\begin{array}{l}\text { Trade of pig meat (fresh or frozen meat or untreated pig } \\
\text { products) }\end{array}$ \\
\hline $\begin{array}{l}\text { Scientific } \\
\text { Committee of the } \\
\text { FASFC (2018) }\end{array}$ & ASFV & Qualitative & $\begin{array}{l}\text { Geographic spreading via wild boars, introduction and spread } \\
\text { in Belgian pig farms, dissemination between infected and } \\
\text { non-infected pig farms }\end{array}$ & $\begin{array}{l}\text { Wild boars (to other wild boars outside of introduction } \\
\text { region of Luxemburg) }\end{array}$ \\
\hline
\end{tabular}

\begin{tabular}{|c|c|c|c|c|}
\hline Jurado et al. (2018) & ASFV & Qualitative & $\begin{array}{l}\text { Wild boar; biosecurity breaches on domestic pig farms } \\
\text { (including movement of animals and semen/ova); swill } \\
\text { feeding; vectors; use of fresh fodder }\end{array}$ & Swill feeding; pig-pig and/or pig-wild boar contact \\
\hline $\begin{array}{l}\text { Beltran-Alcrudo } \\
\text { et al. (2019) }\end{array}$ & ASFV & Qualitative & International trade animals and animals products, and fomites & Not identified \\
\hline MacDiarmid (1991) & CSFV & Qualitative & Importation of meat and meat products & Not identified \\
\hline CFIA (1999) & CSFV & Not identified & $\begin{array}{l}\text { Salted intestinal casings fed to domestic pigs (legally or } \\
\text { illegally imported) }\end{array}$ & Salted intestinal casings fed to wild pigs \\
\hline $\begin{array}{l}\text { Mintiens } \\
\text { et al. (2003) }\end{array}$ & CSFV & Quantitative & Neighbourhood infections & Not identified \\
\hline DeVos et al. (2003) & CSFV & Qualitative & $\begin{array}{l}\text { Imports of genetic material (legal and illegal), returning } \\
\text { livestock trucks, imports of wild animals, imports of batches } \\
\text { of domestic animals, illegal imports of live animals, imports } \\
\text { of animal products for human consumption, illegal imports } \\
\text { of animal products (including tourists), professional staff, } \\
\text { imports of manure, birds, pets, arthropods, and rodents, air } \\
\text { currents, laboratories, harbours and airports, and wildlife }\end{array}$ & Animal movements, swill feeding and wild boar \\
\hline Gale (2004) & CSFV & Quantitative & $\begin{array}{l}\text { Composted catering waste containing uncooked meat } \\
\text { discarded on farm land or fed to animals }\end{array}$ & $\begin{array}{l}\text { Composted uncooked animal waste being fed to farm } \\
\text { animals or distributed near them }\end{array}$ \\
\hline Adkin et al. (2004) & CSFV & Quantitative & $\begin{array}{l}\text { Illegally imported meat and meat products and imported } \\
\text { catering waste (e.g. ship and aircraft waste) }\end{array}$ & $\begin{array}{l}\text { Imports of de-boned meat via air-passenger baggage } \\
\text { most likely to cause subsequent livestock infection } \\
\text { after being introduced }\end{array}$ \\
\hline Vos et al. (2004) & CSFV & Quantitative & $\begin{array}{l}\text { Importation of pigs and pork products, returning livestock } \\
\text { trucks, direct and indirect contact with wild boar, feeding of } \\
\text { improperly heated swill }\end{array}$ & Returning livestock trucks \\
\hline DEFRA (2006) & CSFV & Qualitative & Importation of animal products & Not identified \\
\hline $\begin{array}{l}\text { Wooldridge } \\
\text { et al. (2006) }\end{array}$ & CSFV & Quantitative & $\begin{array}{l}\text { Dried de-deboned meat, and meat that follows human } \\
\text { carriage (litter, 'fly-tipping', direct feeding) }\end{array}$ & Illegal importation of meat by way of passenger baggage \\
\hline DEFRA (2008) & CSFV & Qualitative & Importation of animal products & Not identified \\
\hline $\begin{array}{l}\text { Bronsvoort } \\
\text { et al. (2008) }\end{array}$ & CSFV & Quantitative & $\begin{array}{l}\text { Importation of live swine, importation of swine semen, } \\
\text { returning livestock vehicles, legal importation of meat and } \\
\text { illegal importation of meats }\end{array}$ & Returning livestock trucks and legal meat imports \\
\hline
\end{tabular}




\begin{tabular}{|c|c|c|c|c|c|}
\hline $\begin{array}{l}\text { Assessed geographic } \\
\text { source }\end{array}$ & $\begin{array}{l}\text { Highest risk } \\
\text { geographic source }\end{array}$ & $\begin{array}{l}\text { Assessed } \\
\text { geographic } \\
\text { destination }\end{array}$ & $\begin{array}{l}\text { Highest risk geographic } \\
\text { destination }\end{array}$ & Highest risk consequence & Model \\
\hline Not identified & Not identified & United Kingdom & Not identified & Not identified & $\mathrm{N} / \mathrm{A}$ \\
\hline Not identified & Not identified & United Kingdom & Not identified & Not identified & $\mathrm{N} / \mathrm{A}$ \\
\hline $\begin{array}{l}\text { Sino-Russia border; Sino- } \\
\text { Korean border }\end{array}$ & $\begin{array}{l}\text { Sino-Russian border } \\
\text { section }\end{array}$ & Northern China & Northern China & $\begin{array}{l}\text { Infection of the Sino- } \\
\text { Russian border section }\end{array}$ & Spatial \\
\hline European Union & Romania & United Kingdom & United Kingdom & Not identified & $\mathrm{N} / \mathrm{A}$ \\
\hline $\begin{array}{l}\text { Luxembourg province of } \\
\text { Belgium }\end{array}$ & Not identified & $\begin{array}{l}\text { Belgium (e.g. } \\
\text { further spread } \\
\text { within country } \\
\text { from introduction } \\
\text { site of } \\
\text { Luxembourg) }\end{array}$ & Not identified & Not identified & $\mathrm{N} / \mathrm{A}$ \\
\hline $\begin{array}{l}\text { Infected European Union } \\
\text { countries }\end{array}$ & Not identified & $\begin{array}{l}\text { Domestic farms } \\
\text { within Uninfected } \\
\text { European Union } \\
\text { countries }\end{array}$ & Not identified & Not identified & Literature review \\
\hline Not identified & Not identified & Not identified & Not identified & Not identified & $\mathrm{N} / \mathrm{A}$ \\
\hline Not identified & Not identified & New Zealand & Not identified & Not identified & $\mathrm{N} / \mathrm{A}$ \\
\hline Not identified & Not identified & Canada & Not identified & Not identified & $\mathrm{N} / \mathrm{A}$ \\
\hline Not identified & Not identified & Belgium & $\begin{array}{l}\text { Regions of Belgium (see map } \\
\text { in paper) }\end{array}$ & Areas within Belgium & Logistic regression and spatial \\
\hline Not identified & Not identified & European Union & $\begin{array}{l}\text { Southern Netherlands, } \\
\text { Sudoldenburg Germany, } \\
\text { Hannover Germany, West- } \\
\text { Flanders Belgium, Cotes- } \\
\text { d'Amor France }\end{array}$ & Not identified & $\begin{array}{l}\text { Pathway diagram and conceptual } \\
\text { framework }\end{array}$ \\
\hline United Kingdom & Not identified & United Kingdom & Not identified & $\begin{array}{l}\text { Multiple farm animals } \\
\text { eating bits of the same } \\
\text { contaminated waste, } \\
\text { rather than one single } \\
\text { pig eating all of the } \\
\text { contaminated portion of } \\
\text { waste }\end{array}$ & $\begin{array}{l}\text { Source-pathway-receptor } \\
\text { approach }\end{array}$ \\
\hline Non-EU countries & Western Africa & Great Britain & Not identified & Not identified & Stochastic \\
\hline European Union & $\begin{array}{l}\text { Germany, Belgium, } \\
\text { United Kingdom }\end{array}$ & Netherlands & Netherlands & Not identified & Probability scenario tree \\
\hline Non-EU countries & Not identified & Great Britain & Not identified & Not identified & $\mathrm{N} / \mathrm{A}$ \\
\hline Worldwide & Western Africa & Great Britain & Not identified & Not identified & Common structure model \\
\hline Non-EU countries & Not identified & Great Britain & Not identified & Not identified & $\mathrm{N} / \mathrm{A}$ \\
\hline European Union & Germany, Netherlands & Denmark & Not identified & Not identified & Multi-level binomial \\
\hline
\end{tabular}


TABLE A1 (Continued)

\begin{tabular}{|c|c|c|c|c|}
\hline Authors \& date & Pathogen & Type of study & Assessed pathways of introduction & Highest risk pathway of introduction \\
\hline $\begin{array}{l}\text { Costard } \\
\text { et al. (2009) }\end{array}$ & CSFV & Quantitative & Animal-contact, person- and vehicle-contact, feeding & Not identified \\
\hline $\begin{array}{l}\text { Martínez-López } \\
\text { et al. (2009) }\end{array}$ & CSFV & Quantitative & Importation of infected domestic and wild swine & Importation of domestic swine \\
\hline Hartley (2010) & CSFV & Qualitative & $\begin{array}{l}\text { Legal/illegal importation of pig products, direct and indirect } \\
\text { contact between feral swine and livestock (airborne, faeco- } \\
\text { oral, food borne, vector borne), import or translocation of } \\
\text { feral swine }\end{array}$ & $\begin{array}{l}\text { Oral consumption of illegally imported pig products by } \\
\text { domestic pigs }\end{array}$ \\
\hline $\begin{array}{l}\text { Cardoso de } \\
\text { Carvalho Ferreira } \\
\text { (2013) }\end{array}$ & CSFV & Qualitative & $\begin{array}{l}\text { Transmission between individuals within the same group, } \\
\text { between different groups/individuals on different farms, } \\
\text { and via tick vectors }\end{array}$ & Not identified \\
\hline $\begin{array}{l}\text { Delgado } \\
\text { et al. (2017) }\end{array}$ & CSFV & Both & Not identified & $\begin{array}{l}\text { Movement of goods outside the EU; movements of wild } \\
\text { boar, human contacts with wildlife and humans }\end{array}$ \\
\hline $\begin{array}{l}\text { Gamado } \\
\text { et al. (2017) }\end{array}$ & CSFV & Quantitative & Not identified & Not identified \\
\hline Hwang et al. (2018) & CSFV & $\begin{array}{l}\text { Semi- } \\
\text { quantitative }\end{array}$ & $\begin{array}{l}\text { Migration or natural movement of wildlife, international } \\
\text { human movement, illegal importation of wildlife and wildlife } \\
\text { parts, accidental introduction of disease vector, smuggling } \\
\text { of livestock products, legal importation of wildlife and } \\
\text { wildlife parts }\end{array}$ & $\begin{array}{l}\text { Migration or natural movement of wildlife, illegal } \\
\text { importation of wildlife and wildlife parts, accidental } \\
\text { introduction of a disease vector, smuggling of livestock } \\
\text { products }\end{array}$ \\
\hline $\begin{array}{l}\text { Beltran-Alcrudo } \\
\text { et al. (2019) }\end{array}$ & CSFV & Qualitative & International trade animals and animals products, and fomites & Not identified \\
\hline MacDiarmid (1991) & FMDV & Qualitative & Importation of meat and meat products & Not identified \\
\hline Forbes et al. (1994) & FMDV & Both & $\begin{array}{l}\text { legal and illegal importation of live animals and animal } \\
\text { products, terrorism, commercial passengers, vehicles and } \\
\text { equipment, waste disposal for sea and air transport }\end{array}$ & $\begin{array}{l}\text { Illegally imported meat products ( } 5 \text { year timeframe) or } \\
\text { terrorist/criminal intent ( } 20 \text { year timeframe) }\end{array}$ \\
\hline CFIA (1999) & FMDV & Not identified & $\begin{array}{l}\text { Salted intestinal casings fed to domestic pigs (legally or } \\
\text { illegally imported) }\end{array}$ & Salted intestinal casings fed to wild pigs \\
\hline $\begin{array}{l}\text { Moutou } \\
\text { et al. (2001) }\end{array}$ & FMDV & Qualitative & $\begin{array}{l}\text { Importation or trade of animal and animal products, cross- } \\
\text { border mingling of livestock herds, movement of infected } \\
\text { wildlife }\end{array}$ & Not identified \\
\hline $\begin{array}{l}\text { Pharo and } \\
\text { Biosecurity } \\
\text { Authority (2002) }\end{array}$ & FMDV & Qualitative & Illegally imported meat fed to pigs & Illegally imported meat fed to pigs \\
\hline Pharo (2002) & FMDV & Qualitative & $\begin{array}{l}\text { Legally and illegally imported animals and animal products, } \\
\text { fomites }\end{array}$ & Illegally imported meat fed to pigs \\
\hline DEFRA (2003) & FMDV & Both & Illegal importation of meat and meat products & Personal baggage \\
\hline
\end{tabular}




\begin{tabular}{|c|c|c|c|c|c|}
\hline $\begin{array}{l}\text { Assessed geographic } \\
\text { source }\end{array}$ & $\begin{array}{l}\text { Highest risk } \\
\text { geographic source }\end{array}$ & $\begin{array}{l}\text { Assessed } \\
\text { geographic } \\
\text { destination }\end{array}$ & $\begin{array}{l}\text { Highest risk geographic } \\
\text { destination }\end{array}$ & Highest risk consequence & Model \\
\hline Not identified & Not identified & Madagascar & Not identified & Not identified & $\begin{array}{l}\text { Multiple factor analysis and } \\
\text { hierarchical cluster analysis }\end{array}$ \\
\hline $\begin{array}{l}\text { Countries that export } \\
\text { products to Spain }\end{array}$ & $\begin{array}{l}\text { Netherlands, Germany, } \\
\text { Slovakia, Belgium }\end{array}$ & Spain & $\begin{array}{l}\text { Lerida, Gerona, Huesca, } \\
\text { Barcelona and Zaragoza } \\
\text { provinces of Spain }\end{array}$ & Not identified & Stochastic \\
\hline Not identified & Not identified & England & Not identified & $\begin{array}{l}\text { Introduction into wild boar } \\
\text { population/spread and } \\
\text { duration of the disease }\end{array}$ & N/A \\
\hline Not identified & Not identified & Not identified & Not identified & $\begin{array}{l}\text { Within and between group } \\
\text { transmission }\end{array}$ & Descriptive \\
\hline Not identified & Not identified & $\begin{array}{l}\text { England, United } \\
\text { Kingdom }\end{array}$ & Not identified & Not identified & Network model \\
\hline Not identified & Not identified & $\begin{array}{l}\text { East Anglia, United } \\
\text { Kingdom }\end{array}$ & Not identified & Not identified & $\begin{array}{l}\text { Stochastic spatio-temporal } \\
\text { Susceptible-Infectious-Removed } \\
\text { (SIR) epidemic model }\end{array}$ \\
\hline Not identified & Not identified & Republic of Korea & Not identified & Not identified & N/A \\
\hline
\end{tabular}

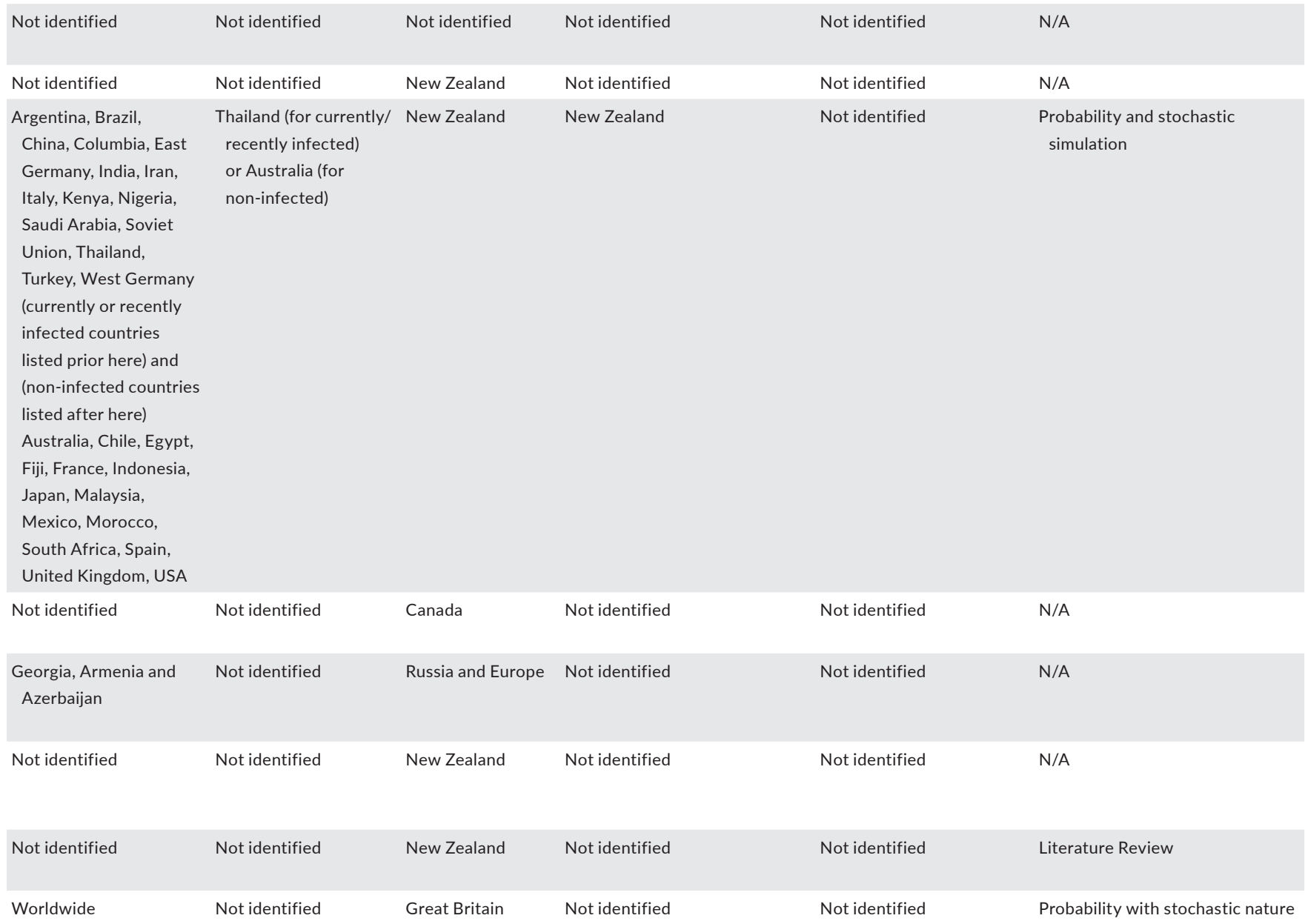


TABLE A1 (Continued)

\begin{tabular}{|c|c|c|c|}
\hline Authors \& date & Pathogen & Type of study & Assessed pathways of introduction \\
\hline $\begin{array}{l}\text { Sutmoller and } \\
\text { Olascoaga (2003) }\end{array}$ & FMDV & Qualitative & $\begin{array}{l}\text { Importation of FMDV vaccinated live animals and animal } \\
\text { products from vaccinated animals (meat, meat products, } \\
\text { milk and dairy products, bovine embryos, semen }\end{array}$ \\
\hline Adkin et al. (2004) & FMDV & Quantitative & $\begin{array}{l}\text { Illegally imported meat and meat products and imported } \\
\text { catering waste (e.g. ship and aircraft waste) }\end{array}$ \\
\hline Gale (2004) & FMDV & Quantitative & $\begin{array}{l}\text { Composted catering waste containing uncooked meat } \\
\text { discarded on farm land or fed to animals }\end{array}$ \\
\hline $\begin{array}{l}\text { Schijven } \\
\text { et al. (2005) }\end{array}$ & FMDV & Quantitative & $\begin{array}{l}\text { Illegal discharge of contaminated milk in sewerage resulting } \\
\text { in livestock contact with contaminated surface water from } \\
\text { treatment plants }\end{array}$ \\
\hline Hong et al. (2005) & FMDV & Quantitative & Contaminated smuggled animal products fed to swine \\
\hline DEFRA (2006) & FMDV & Qualitative & Importation of animal products \\
\hline $\begin{array}{l}\text { Wooldridge } \\
\text { et al. (2006) }\end{array}$ & FMDV & Quantitative & $\begin{array}{l}\text { Cattle and pig meat, and meat that follows human carriage } \\
\text { (litter, 'fly-tipping', direct feeding) }\end{array}$ \\
\hline EFSA (2006) & FMDV & Qualitative & $\begin{array}{l}\text { Legal and illegal importation of infected animals and } \\
\text { contaminated animal products, contaminated fomites (i.e. } \\
\text { trucks) }\end{array}$ \\
\hline $\begin{array}{l}\text { Hartnett } \\
\text { et al. (2007) }\end{array}$ & FMDV & Quantitative & Illegally imported contaminated meat \\
\hline
\end{tabular}

Highest risk pathway of introduction

Not identified

Imports of cattle and pig meat via passenger baggage pose highest risk to livestock infection

Composted uncooked animal waste being fed to farm animals or distributed near them
Not identified

Feeding contaminated waste to susceptible swine

Not identified

Illegal importation of meat by way of passenger baggage

Illegally imported animal products

Illegal import of bone-in and dried de-boned products from cattle and pigs in passenger baggage

\begin{tabular}{|c|c|c|c|c|}
\hline DEFRA (2008) & FMDV & Quantitative & Importation of animal products & Not identified \\
\hline Rodeia (2008) & FMDV & Qualitative & Not identified & Not identified \\
\hline $\begin{array}{l}\text { Bender } \\
\text { et al. (2006) }\end{array}$ & FMDV & Qualitative & $\begin{array}{l}\text { Direct contact between animals, aerosol from infected } \\
\text { animals or milk trucks, fomites, artificial insemination }\end{array}$ & Not identified \\
\hline $\begin{array}{l}\text { Martínez-López } \\
\text { et al. (2008) }\end{array}$ & FMDV & Quantitative & Legal importation of live animals & Import of pigs \\
\hline Hartley (2010) & FMDV & Qualitative & $\begin{array}{l}\text { Legal/illegal importation of pig products, direct and indirect } \\
\text { contact between feral swine and livestock (airborne, faeco- } \\
\text { oral, food borne, vector borne), import or translocation of } \\
\text { feral swine }\end{array}$ & $\begin{array}{l}\text { Oral consumption of illegally imported pig products by } \\
\text { domestic pigs }\end{array}$ \\
\hline $\begin{array}{l}\text { Wieland } \\
\text { et al. (2015) }\end{array}$ & FMDV & Qualitative & $\begin{array}{l}\text { Livestock, animal-derived products, feed, vehicles/fomites, } \\
\text { people, wildlife, aerosol and water }\end{array}$ & Cross-border movement of livestock \\
\hline Dewey et al. (2014) & FMDV & Qualitative & Fomites (people, boots, vehicles, feed bags) & Not identified \\
\hline
\end{tabular}

$\begin{array}{llccc}\begin{array}{l}\text { Şenturk } \\ \text { et al. (2016) }\end{array} & \text { FMDV } & \text { Quantitative } & \begin{array}{c}\text { Animal production chain aspects including input, processing, } \\ \text { production, movement and marketing infrastructure }\end{array} & \text { Importation of animals } \\ \begin{array}{c}\text { Hernández-Jover } \\ \text { et al. (2016) }\end{array} & \text { FMDV } & \text { Both } & \text { Illegal importation of infected meat } & \text { Direct feeding of infected meat to pigs at small-scale } \\ \text { piggeries }\end{array}$




\begin{tabular}{|c|c|c|c|c|c|}
\hline $\begin{array}{l}\text { Assessed geographic } \\
\text { source }\end{array}$ & $\begin{array}{l}\text { Highest risk } \\
\text { geographic source }\end{array}$ & $\begin{array}{l}\text { Assessed } \\
\text { geographic } \\
\text { destination }\end{array}$ & $\begin{array}{l}\text { Highest risk geographic } \\
\text { destination }\end{array}$ & Highest risk consequence & Model \\
\hline Not identified & Not identified & Not identified & Not identified & Not identified & $\mathrm{N} / \mathrm{A}$ \\
\hline $\begin{array}{l}\text { Countries outside the } \\
\text { European Union }\end{array}$ & Near and Middle East & Great Britain & Not identified & Not identified & Stochastic \\
\hline United Kingdom & Not identified & United Kingdom & Not identified & $\begin{array}{l}\text { Multiple farm animals } \\
\text { eating bits of the same } \\
\text { contaminated waste, } \\
\text { rather than one single } \\
\text { pig eating all of the } \\
\text { contaminated portion of } \\
\text { waste }\end{array}$ & $\begin{array}{l}\text { Source-pathway-receptor } \\
\text { approach }\end{array}$ \\
\hline Not identified & Not identified & Not identified & Not identified & Not identified & Dose-response model \\
\hline Not identified & Not identified & South Korea & Not identified & Not identified & Monte Carlo Simulation \\
\hline Non-EU countries & Not identified & Great Britain & Not identified & Not identified & $\mathrm{N} / \mathrm{A}$ \\
\hline Worldwide & Near and Middle East & Great Britain & Not identified & Not identified & Common structure model \\
\hline $\begin{array}{l}\text { Infected non-EU } \\
\text { countries }\end{array}$ & $\begin{array}{l}\text { Southeast Asia, China, } \\
\text { South Asia }\end{array}$ & European Union & Europe & $\begin{array}{l}\text { Introduction of infected } \\
\text { live animal }\end{array}$ & $\mathrm{N} / \mathrm{A}$ \\
\hline $\begin{array}{l}\text { Eastern Asia, Near and } \\
\text { Middle East, Eastern } \\
\text { Europe, Southern } \\
\text { Africa, Western } \\
\text { Africa, North America, } \\
\text { Caribbean, Southern } \\
\text { Asia, Eastern Africa, } \\
\text { Oceania, Central and } \\
\text { South America, South- } \\
\text { eastern Asia, Northern } \\
\text { Africa, Central Africa }\end{array}$ & $\begin{array}{l}\text { Near and Middle East } \\
\text { region }\end{array}$ & Great Britain & Great Britain & Not identified & $\begin{array}{l}\text { Object-oriented simulation of } \\
\text { flow, probability, Monte Carlo } \\
\text { simulation }\end{array}$ \\
\hline Non-EU countries & Not identified & Great Britain & Not identified & Not identified & $\mathrm{N} / \mathrm{A}$ \\
\hline Not identified & $\begin{array}{l}\text { Southeast Asia, China, } \\
\text { South Asia }\end{array}$ & European Union & Europe & Not identified & $\mathrm{N} / \mathrm{A}$ \\
\hline Not identified & Not identified & Not identified & Not identified & Not identified & $\mathrm{N} / \mathrm{A}$ \\
\hline European Union & Not identified & Spain & North-eastern Spain & Not identified & $\begin{array}{l}\text { Binomial probability, Monte Carlo } \\
\text { approach }\end{array}$ \\
\hline Not identified & Not identified & England & Not identified & $\begin{array}{l}\text { Introduction into wild boar } \\
\text { population/spread and } \\
\text { duration of the disease }\end{array}$ & $\mathrm{N} / \mathrm{A}$ \\
\hline Mongolia & $\begin{array}{l}\text { Mongolia (eastern } \\
\text { region) }\end{array}$ & Mongolia & Mongolia (western region) & Not identified & $\mathrm{N} / \mathrm{A}$ \\
\hline Canada (Ontario) & Not identified & Canada (Ontario) & Not identified & Not identified & $\begin{array}{l}\text { Focus groups and interviews of } \\
\text { feed-company personnel and } \\
\text { swine producers }\end{array}$ \\
\hline Not identified & Not identified & $\begin{array}{l}\text { Turkey (Samsun } \\
\text { Province) }\end{array}$ & Not identified & Not identified & Linear regression \\
\hline Not identified & Not identified & Australia & Not identified & Not identified & $\begin{array}{l}\text { Scenario trees and Monte Carlo } \\
\text { stochastic simulation }\end{array}$ \\
\hline
\end{tabular}


TABLE A1 (Continued)

\begin{tabular}{|c|c|c|c|c|}
\hline Authors \& date & Pathogen & Type of study & Assessed pathways of introduction & Highest risk pathway of introduction \\
\hline DEFRA (2017) & FMDV & Both & $\begin{array}{l}\text { Commercial and personal importations of products of animal } \\
\text { origin; live animals commercial and personal imports and the } \\
\text { EU Pet Travel Scheme; commercial and personal imports of } \\
\text { plant and plant products (including wood, wood products } \\
\text { and bark); veterinary medicines (commercial and personal } \\
\text { import of illegal veterinary medicines) }\end{array}$ & Meat and dairy products \\
\hline $\begin{array}{l}\text { Delgado } \\
\text { et al. (2017) }\end{array}$ & FMDV & $\begin{array}{l}\text { Semi- } \\
\text { quantitative }\end{array}$ & $\begin{array}{l}\text { Legal and illegal movements of animals and animal products, } \\
\text { and airborne transmission }\end{array}$ & $\begin{array}{l}\text { Legal, non-commercial movement of people and goods } \\
\text { across and within borders of live animals and animal } \\
\text { products }\end{array}$ \\
\hline
\end{tabular}

\begin{tabular}{|c|c|c|c|c|}
\hline $\begin{array}{l}\text { Goldsmith } \\
\text { et al. (2017) }\end{array}$ & FMDV & Qualitative & Not identified & Not identified \\
\hline $\begin{array}{l}\text { Beltran-Alcrudo } \\
\text { et al. (2019) }\end{array}$ & FMDV & Qualitative & International trade animals and animals products, and fomites & Not identified \\
\hline Davidson (1992) & $\begin{array}{l}\text { Not } \\
\text { identified }\end{array}$ & Quantitative & Importations of animal materials by mail or air passengers & Animal products imported by air passengers \\
\hline Shih et al. (2005) & $\begin{array}{l}\text { Not } \\
\text { identified }\end{array}$ & Quantitative & $\begin{array}{l}\text { Illegal importation of animal products by air passenger } \\
\text { baggage }\end{array}$ & Not identified \\
\hline Whyte (2006) & $\begin{array}{l}\text { Not } \\
\text { identified }\end{array}$ & Qualitative & $\begin{array}{l}\text { Legal and illegal imports (including infected materials brought } \\
\text { in passenger baggage and sent in the mail) }\end{array}$ & Not identified \\
\hline $\begin{array}{l}\text { Chaber } \\
\text { et al. (2010) }\end{array}$ & $\begin{array}{l}\text { Not } \\
\text { identified }\end{array}$ & Qualitative & Illegally imported bushmeat by air passenger & Not identified \\
\hline $\begin{array}{l}\text { Noordhuizen } \\
\text { et al. (2013) }\end{array}$ & $\begin{array}{l}\text { Not } \\
\text { identified }\end{array}$ & Qualitative & $\begin{array}{l}\text { Illegal importation of animals and animal products by } \\
\text { travellers }\end{array}$ & Not identified \\
\hline Falk et al. (2013) & $\begin{array}{l}\text { Not } \\
\text { identified }\end{array}$ & Qualitative & $\begin{array}{l}\text { Illegal importation of bushmeat and meat products by air } \\
\text { passenger baggage }\end{array}$ & Not identified \\
\hline $\begin{array}{l}\text { Porphyre } \\
\text { et al. (2014) }\end{array}$ & $\begin{array}{l}\text { Not } \\
\text { identified }\end{array}$ & Both & Fomites and human mediated movement & Not identified \\
\hline Melo et al. (2014) & $\begin{array}{l}\text { Not } \\
\text { identified }\end{array}$ & Quantitative & Illegal importation of animal products via air travel & Not identified \\
\hline $\begin{array}{l}\text { Beutlich } \\
\text { et al. (2015) }\end{array}$ & $\begin{array}{l}\text { Not } \\
\text { identified }\end{array}$ & Qualitative & Illegally imported food by air passenger & Air passenger baggage \\
\hline Jansen et al. (2016) & $\begin{array}{l}\text { Not } \\
\text { identified }\end{array}$ & Both & $\begin{array}{l}\text { Illegal importation of products of animal origin by air } \\
\text { passenger }\end{array}$ & Not identified \\
\hline
\end{tabular}




\begin{tabular}{|c|c|c|c|c|c|}
\hline $\begin{array}{l}\text { Assessed geographic } \\
\text { source }\end{array}$ & $\begin{array}{l}\text { Highest risk } \\
\text { geographic source }\end{array}$ & $\begin{array}{l}\text { Assessed } \\
\text { geographic } \\
\text { destination }\end{array}$ & $\begin{array}{l}\text { Highest risk geographic } \\
\text { destination }\end{array}$ & Highest risk consequence & Model \\
\hline Worldwide & $\begin{array}{l}\text { Passengers returning } \\
\text { from Southern and } \\
\text { Eastern Asia, Near } \\
\text { and Middle East, and } \\
\text { West Africa }\end{array}$ & United Kingdom & Not identified & Not identified & $\mathrm{N} / \mathrm{A}$ \\
\hline $\begin{array}{l}\text { Non-EU trading } \\
\text { partners/countries, } \\
\text { EU member countries } \\
\text { with confirmed } \\
\text { FMDV outbreaks and } \\
\text { laboratories }\end{array}$ & $\begin{array}{l}\text { European Union and } \\
\text { trading partners with } \\
\text { FMDV outbreaks }\end{array}$ & United Kingdom & United Kingdom & Not identified & Systemic model \\
\hline Not identified & Not identified & Not identified & Not identified & Not identified & $\mathrm{N} / \mathrm{A}$ \\
\hline Not identified & Not identified & Not identified & Not identified & Not identified & $\mathrm{N} / \mathrm{A}$ \\
\hline Not identified & Not identified & New Zealand & Not identified & Not identified & N/A \\
\hline Worldwide & China and Hong Kong & Taiwan & CKS International Airport & Not identified & Monte Carlo Simulation \\
\hline Not identified & Not identified & New Zealand & New Zealand & Not identified & $\mathrm{N} / \mathrm{A}$ \\
\hline Sub-Saharan Africa & $\begin{array}{l}\text { Central African } \\
\text { Republic, Cameroon, } \\
\text { Republic of Congo }\end{array}$ & France & Not identified & Not identified & $\mathrm{N} / \mathrm{A}$ \\
\hline Worldwide & Not identified & European Union & Not identified & Not identified & $\mathrm{N} / \mathrm{A}$ \\
\hline Worldwide & Kosovo & $\begin{array}{l}\text { Switzerland (Zurich } \\
\text { and Geneva } \\
\text { airports) }\end{array}$ & Not identified & Not identified & Stochastic model \\
\hline Scotland & Not identified & Scotland & Not identified & Not identified & External-Internal Index \\
\hline Worldwide & $\begin{array}{l}\text { Eastern Europe, } \\
\text { Portugal }\end{array}$ & Brazil & Not identified & Not identified & $\begin{array}{l}\text { Chi square, logistic regression and } \\
\text { odds ratios }\end{array}$ \\
\hline Worldwide & Turkey and Russia & Germany & Not identified & Not identified & $\mathrm{N} / \mathrm{A}$ \\
\hline Worldwide & $\begin{array}{l}\text { Meat- Russia and the } \\
\text { Caucasus, Dairy- } \\
\text { Turkey and Middle } \\
\text { East }\end{array}$ & Germany & International airports & Not identified & $\mathrm{N} / \mathrm{A}$ \\
\hline Worldwide & China & $\begin{array}{l}\text { Brazil - GRU/SBGR } \\
\text { Airport }\end{array}$ & Not identified & Not identified & $\mathrm{N} / \mathrm{A}$ \\
\hline
\end{tabular}




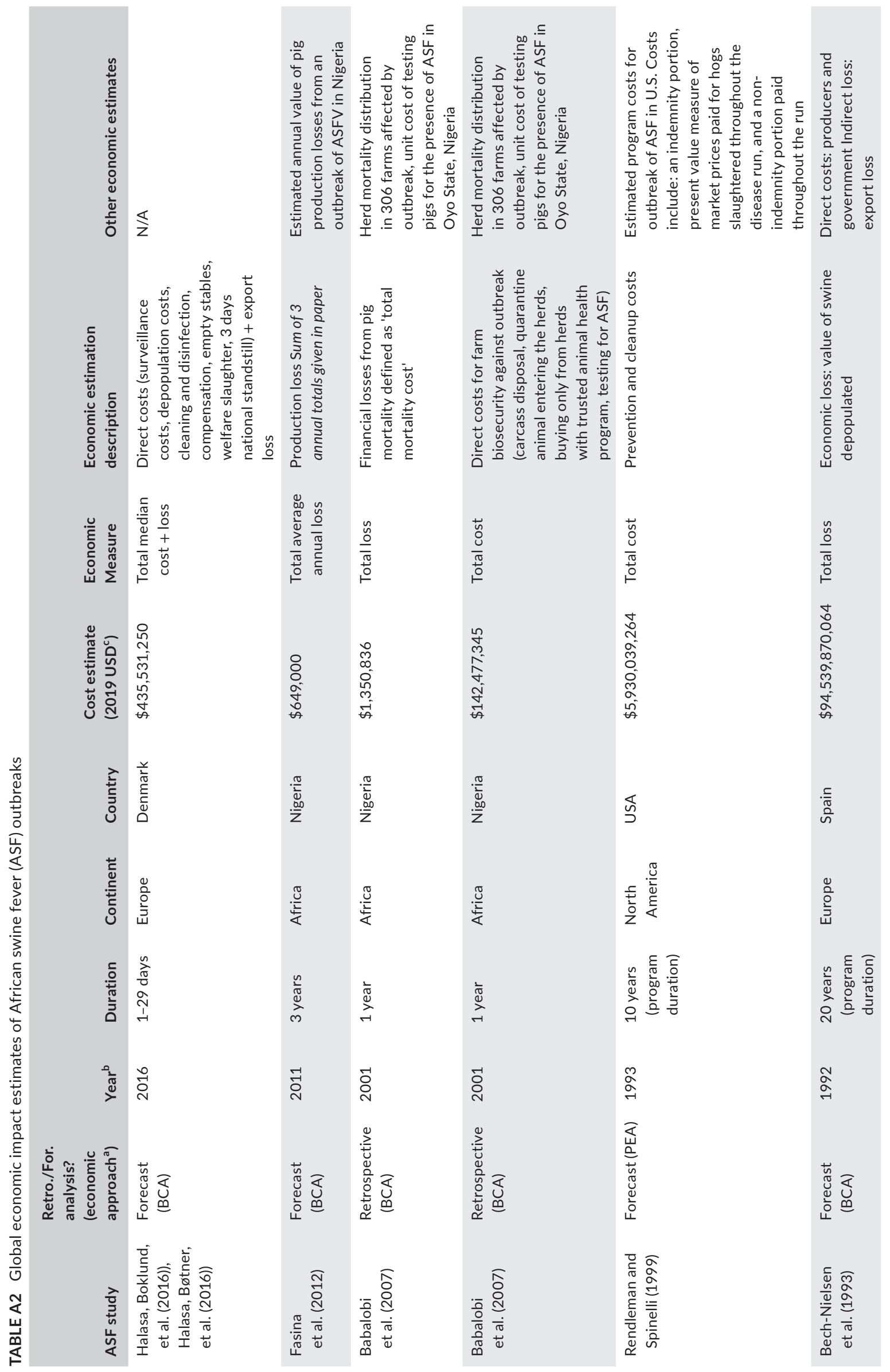




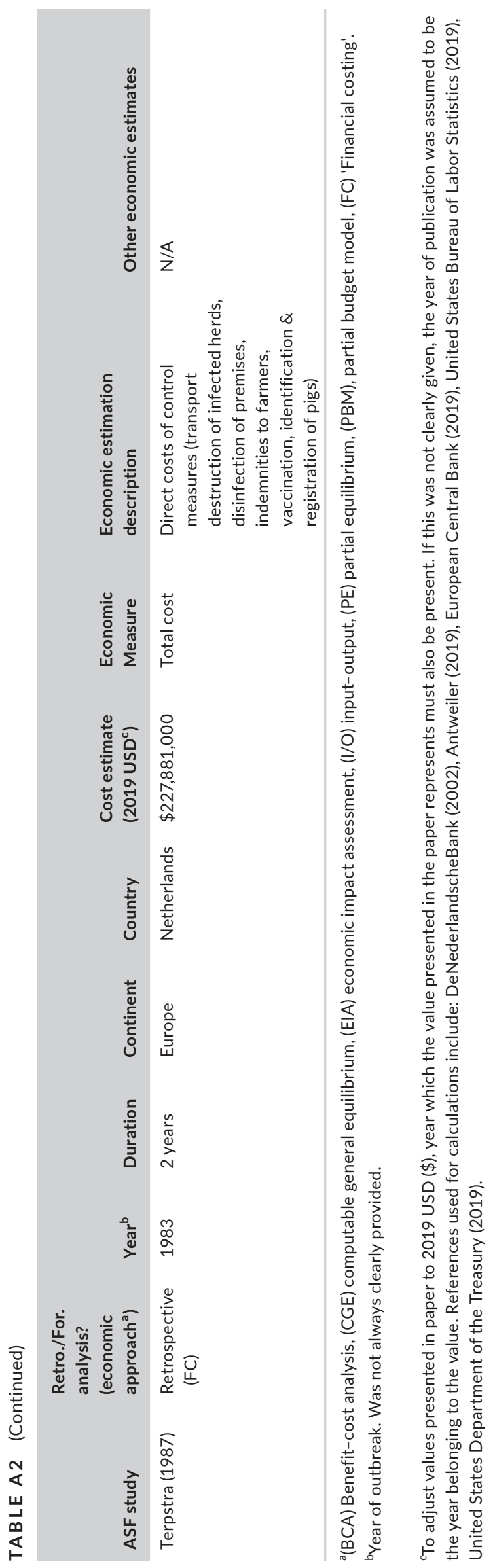




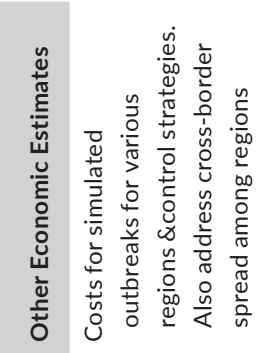

$\frac{5}{z}$
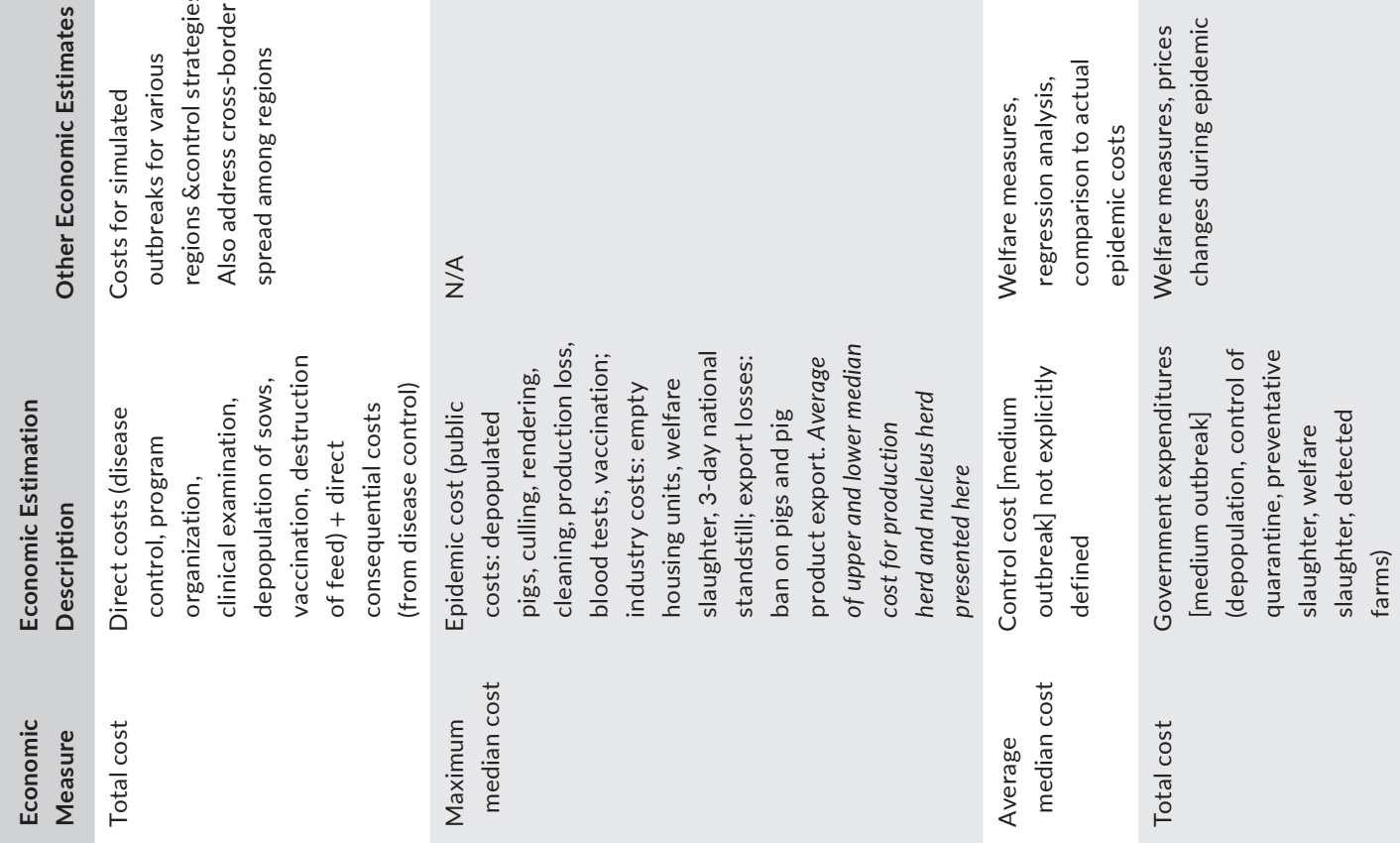

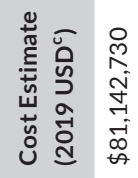
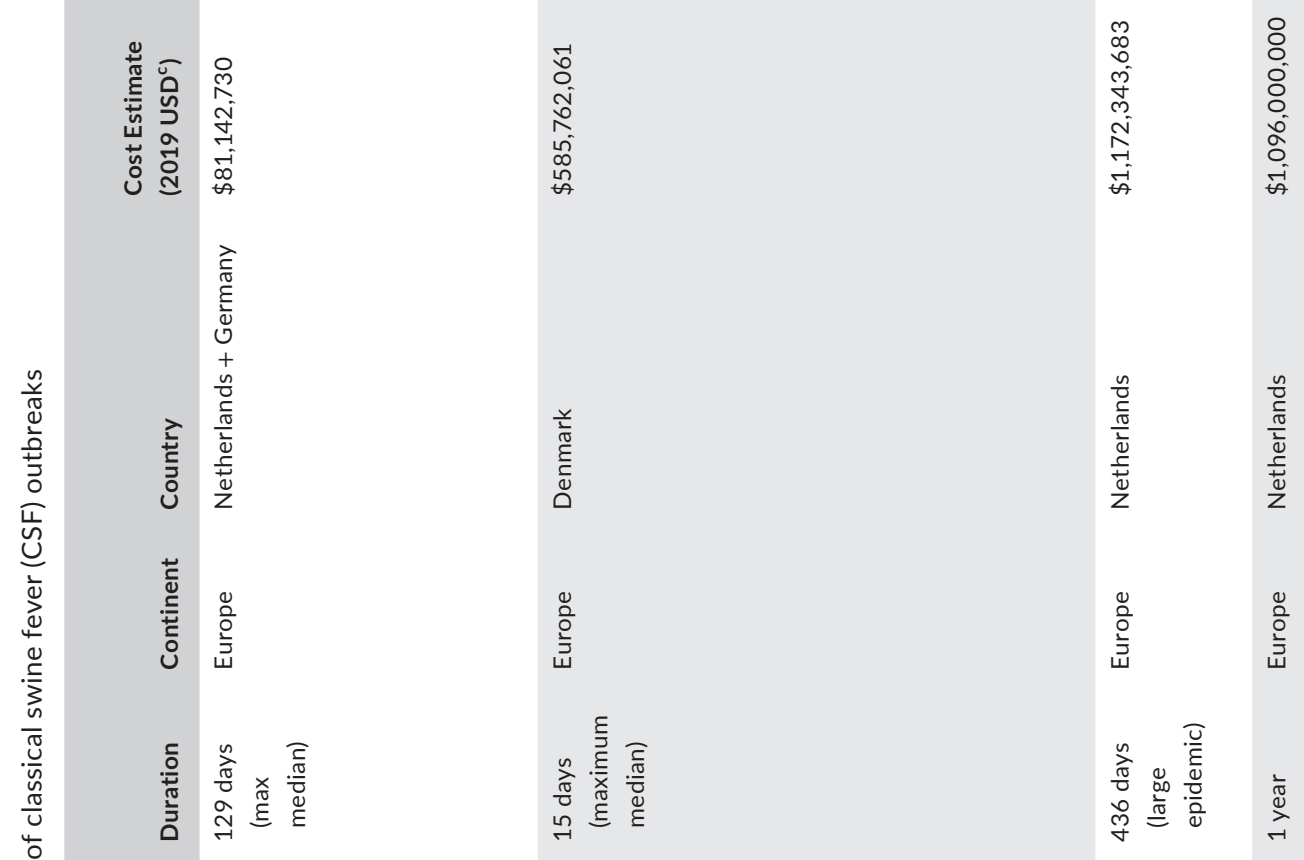

Фั.

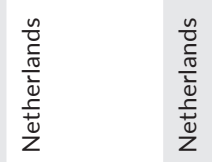

을

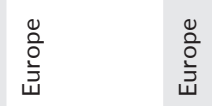
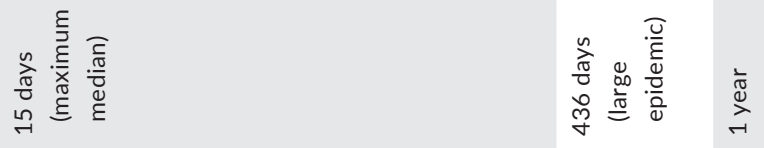

ֻั๊

$\overleftarrow{z}$

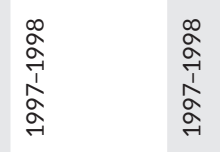

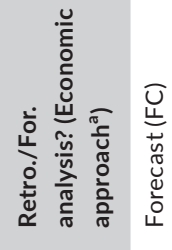

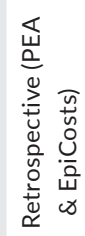

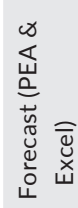

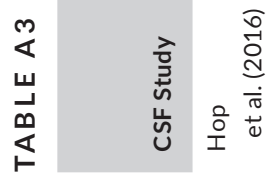

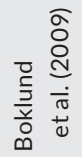

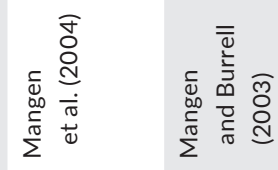




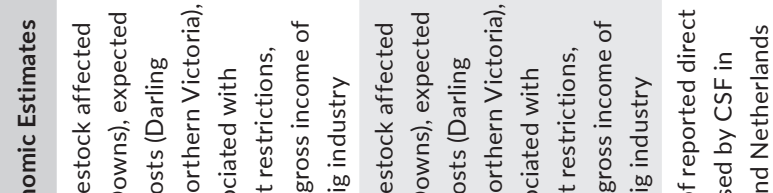

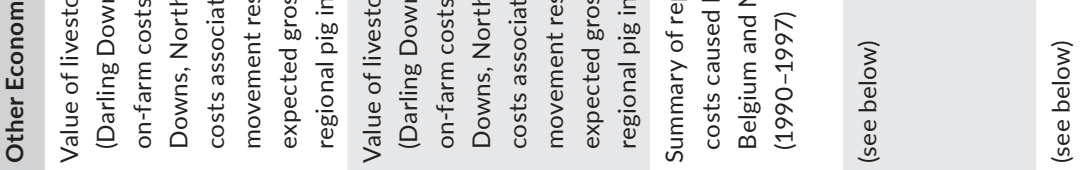

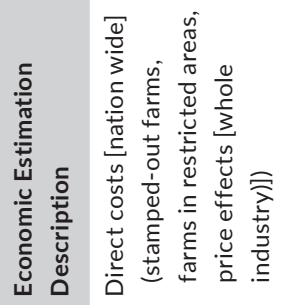

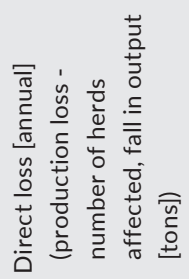

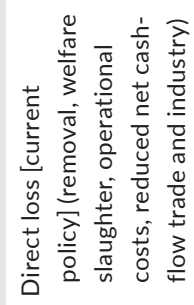

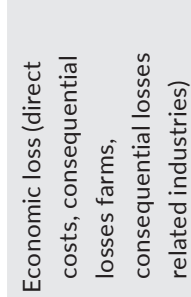

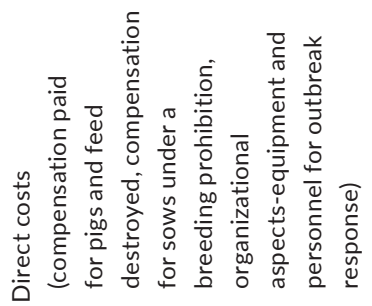

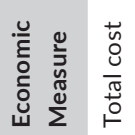

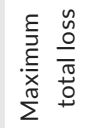

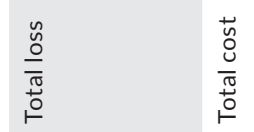

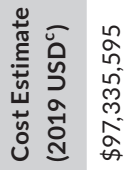

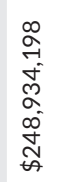

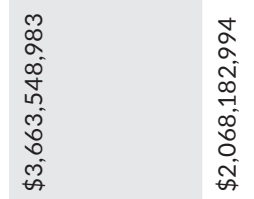

辛

$\frac{\sqrt{\frac{\pi}{\pi}}}{\frac{\sqrt{5}}{3}}$

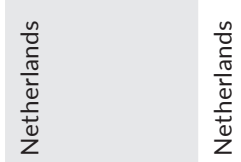

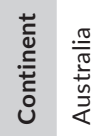

$\frac{\frac{\pi}{\frac{\pi}{5}}}{\frac{\pi}{40}}$

$\frac{n}{0}$
$\frac{0}{0}$
$\frac{0}{0}$
$\frac{5}{0}$
$z$
$\varepsilon$
$\frac{5}{0}$
$\frac{5}{00}$
$\infty$

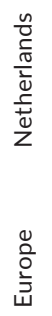

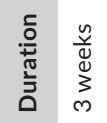

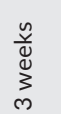

옹

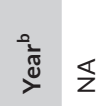

$\overleftarrow{z}$

0
$\stackrel{0}{0}$
$\stackrel{5}{3}$

$\frac{\sqrt{0}}{\frac{0}{0}}$

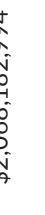

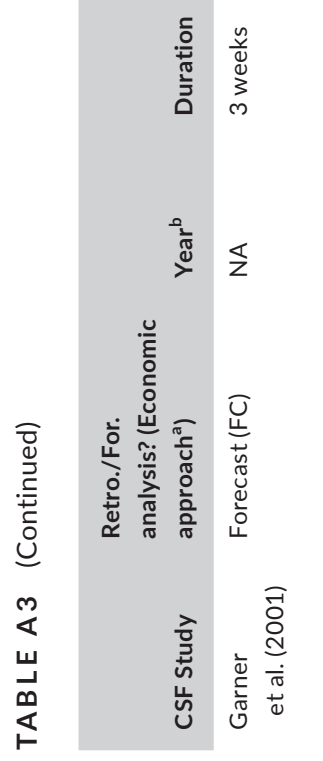

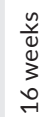

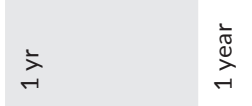

$\S$

$\infty$
$\stackrel{2}{a}$
$\frac{1}{\alpha}$
$\frac{a}{\sigma}$

$\infty$
$\frac{2}{\sigma}$
$\frac{1}{\alpha}$
$\frac{a}{a}$

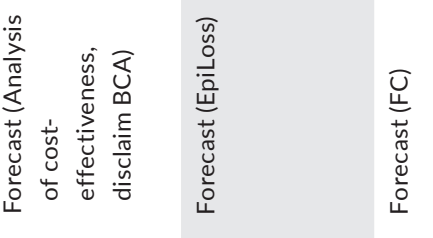

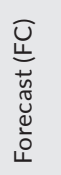

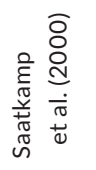

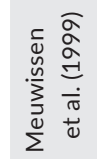

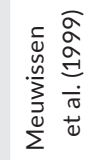




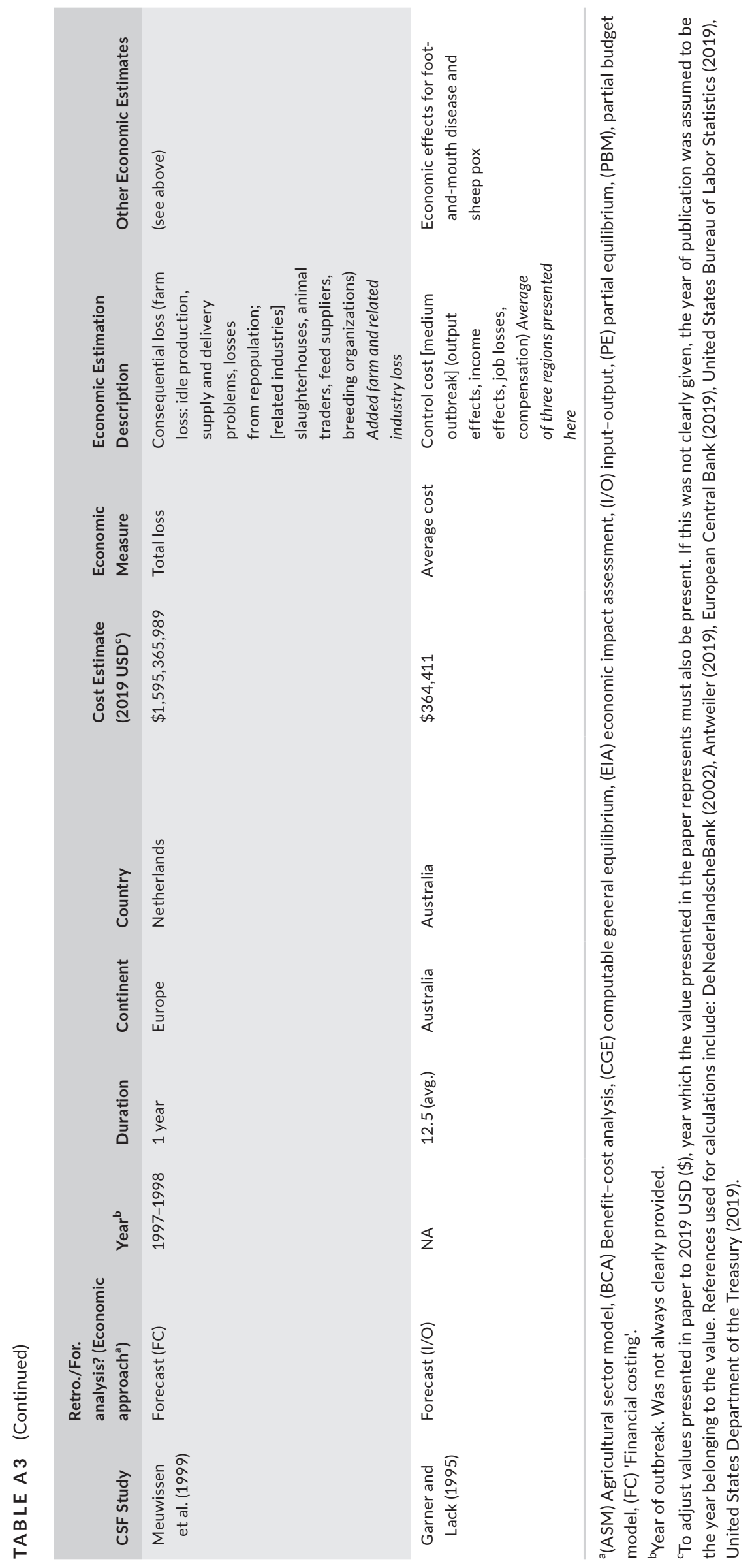



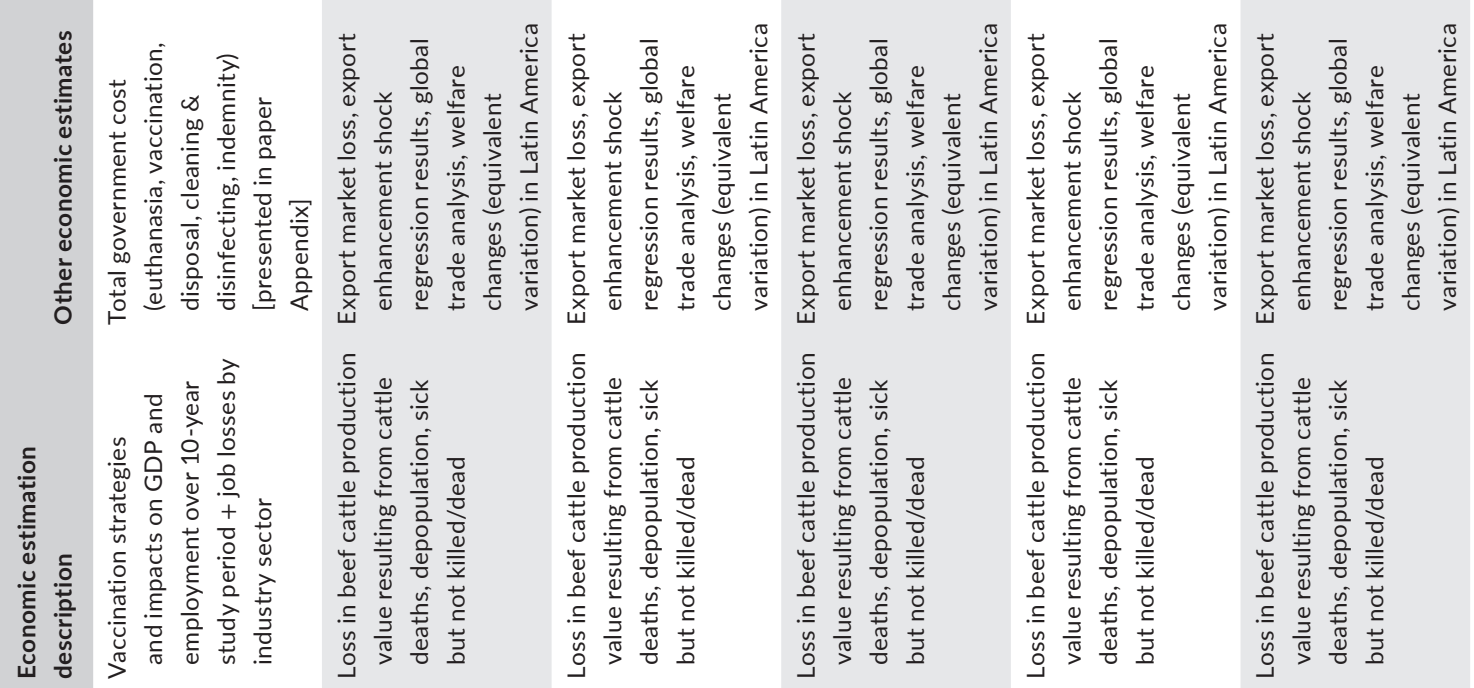

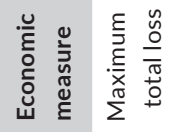

$\widetilde{n}$
$\frac{0}{\pi}$
$\stackrel{\widetilde{0}}{\circ}$

$\tilde{n}$
$\stackrel{0}{\pi}$
$\stackrel{0}{0}$
$\stackrel{0}{0}$

$\frac{\tilde{u}}{\stackrel{0}{\pi}}$

$\tilde{n}$
$\stackrel{0}{\bar{\pi}}$
$\stackrel{0}{\circ}$

$\widetilde{0}$
$\frac{0}{\pi}$
$\stackrel{0}{0}$

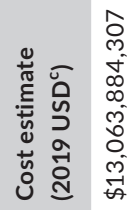

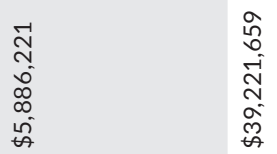

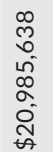

ơ

ָั

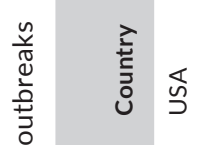

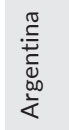

$\frac{\sqrt{0}}{3}$

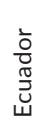

$\frac{\pi}{\frac{\pi}{\omega}}$

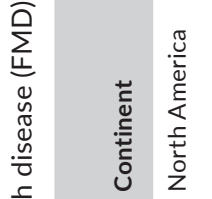

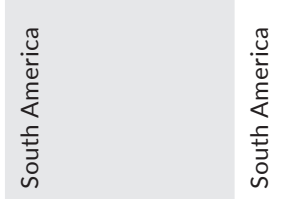

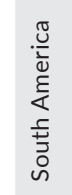

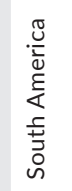

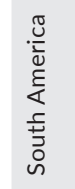

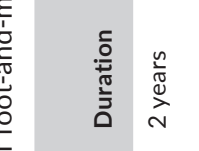

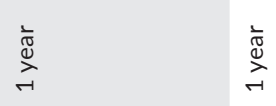

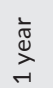

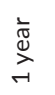

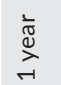

ڤั่

इ

ฐ

亏ั

亏
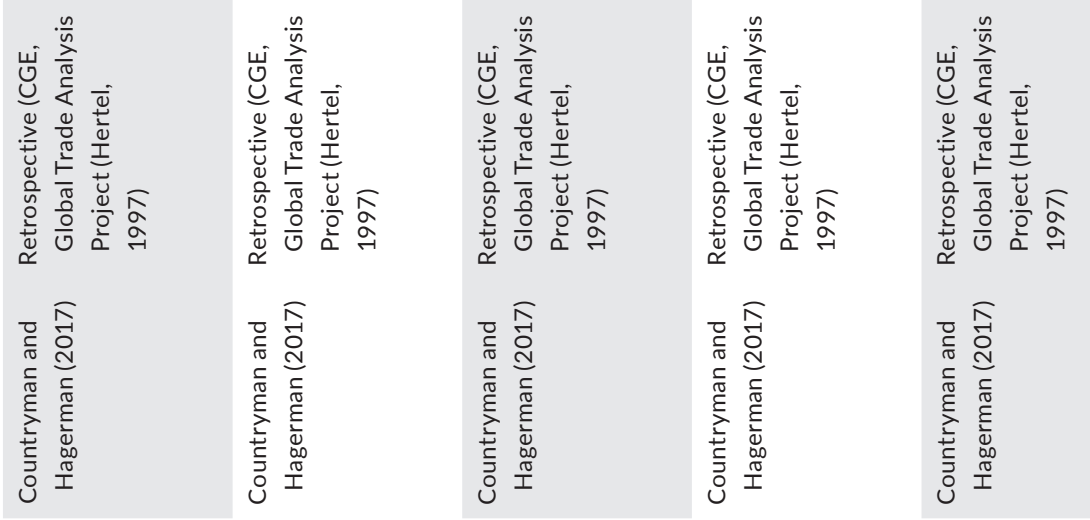


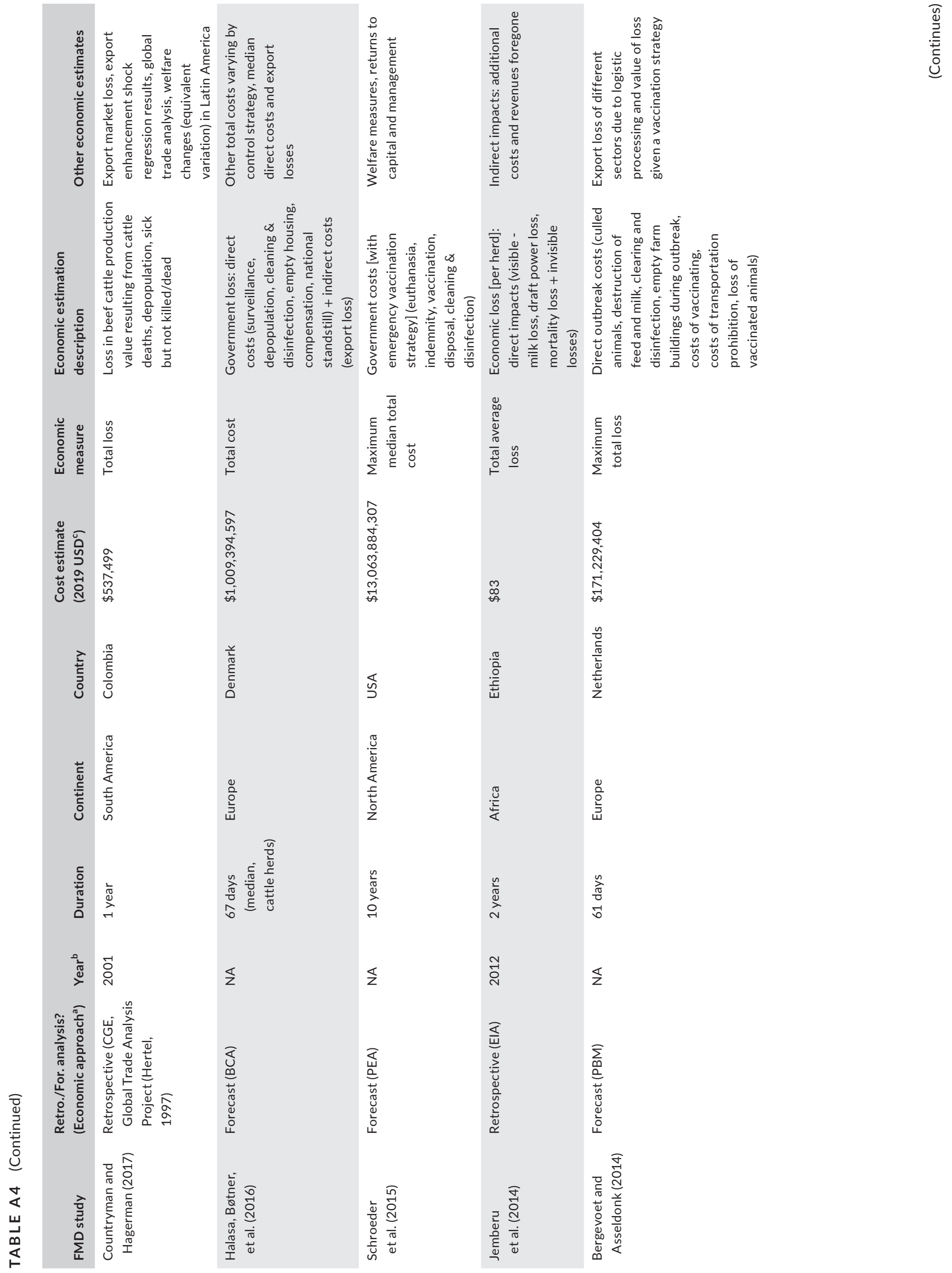



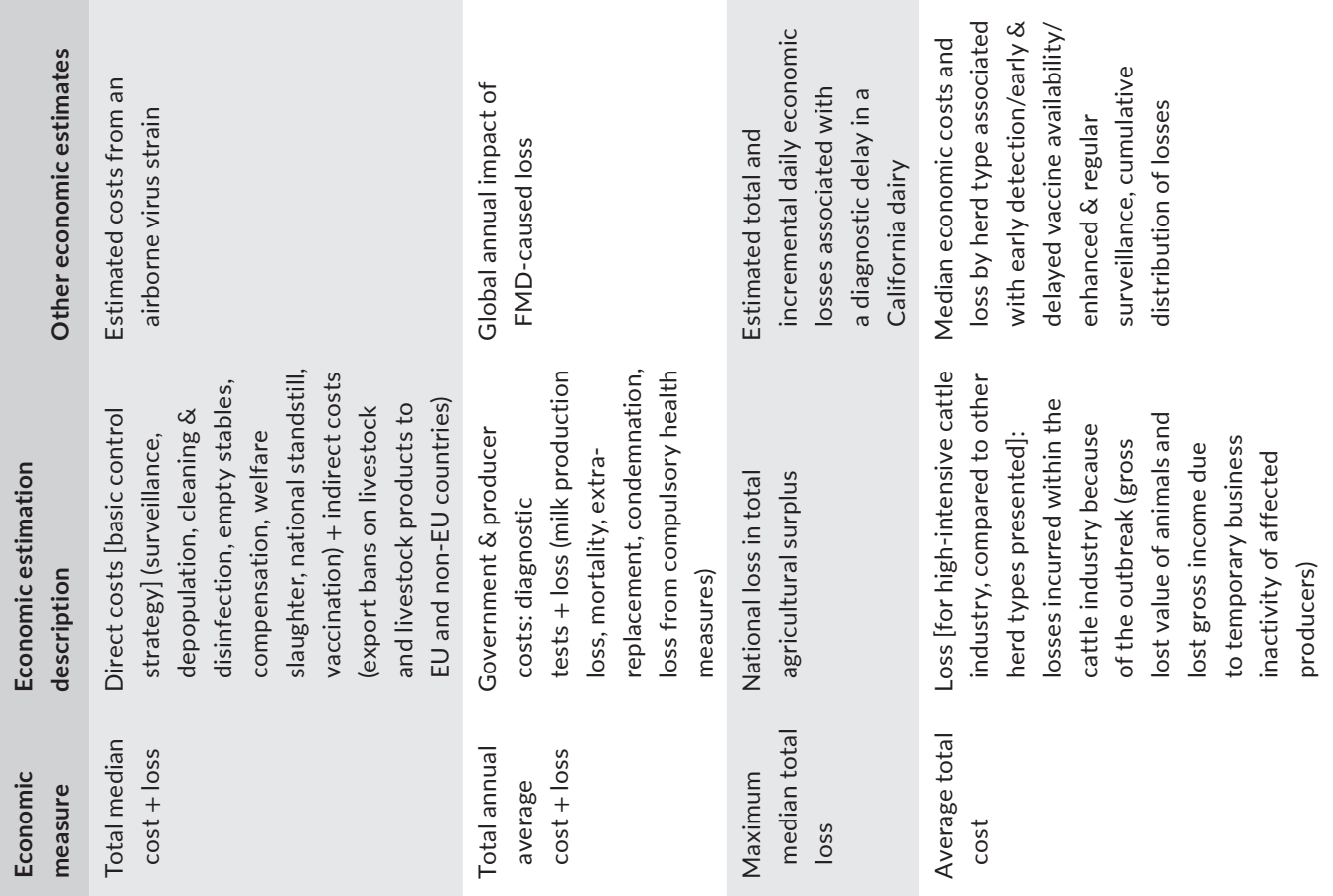

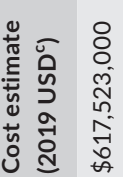
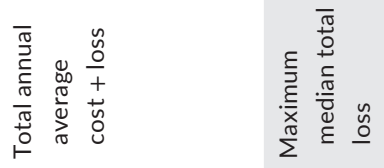

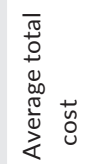

章

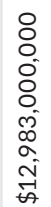

0
8
0
0
0
0
0
0
0
0
0

苗

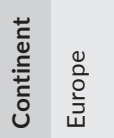

임
응

范

ฐัง

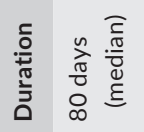

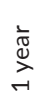

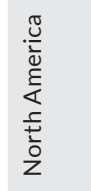

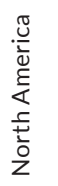

离

$\stackrel{s}{z}$

ํ.

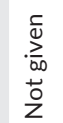

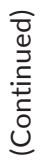

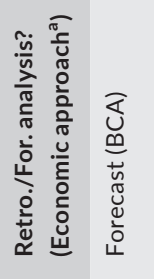

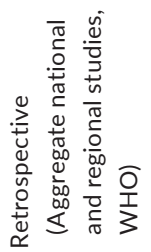

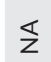

$\frac{s}{z}$

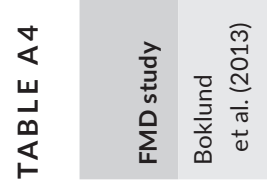

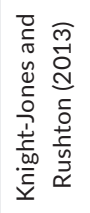

竞

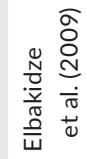



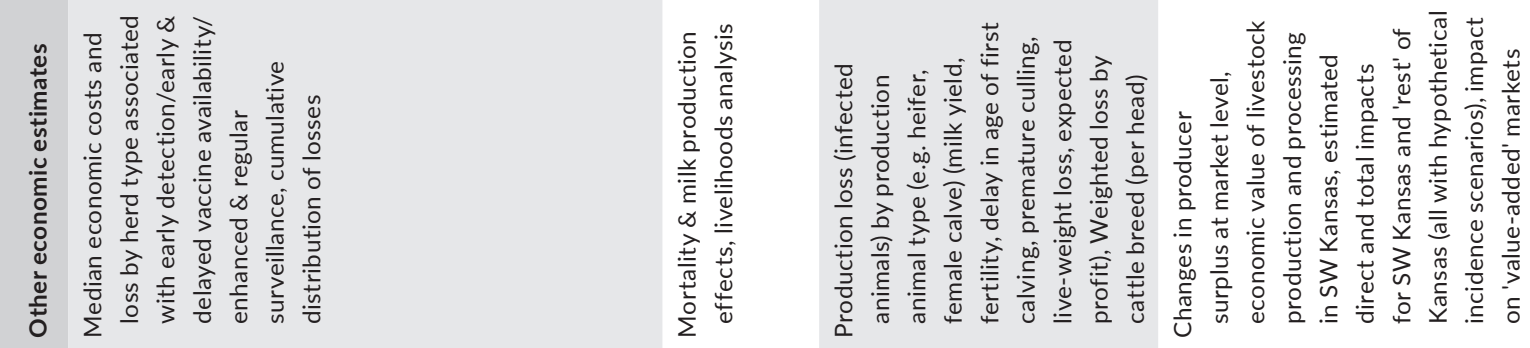

矛
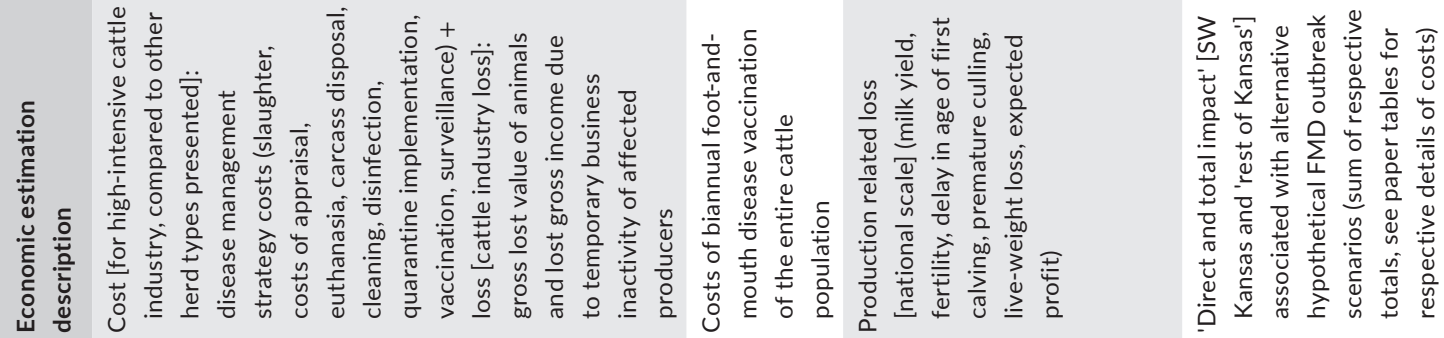

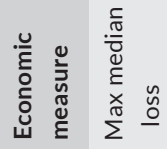

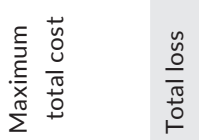

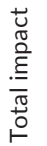

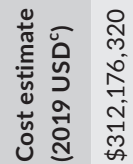

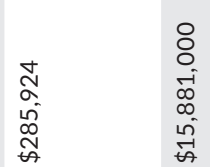

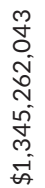

ปั

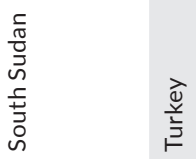

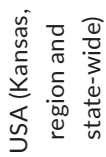

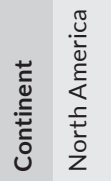<smiles></smiles>

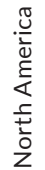

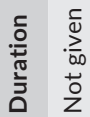<smiles>CCCC</smiles>

$\underset{\substack{n \\ \frac{\pi}{0}}}{\stackrel{n}{\infty}}$

ฝั

ঃ্

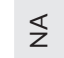

ź

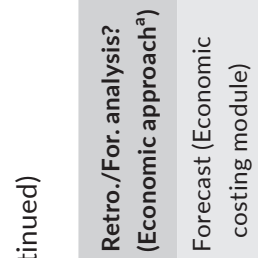

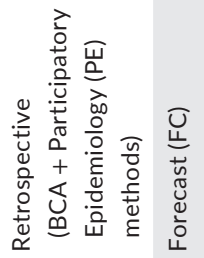

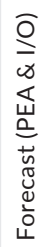

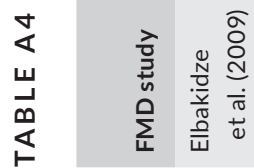

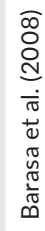

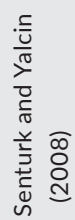

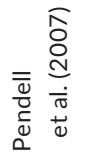



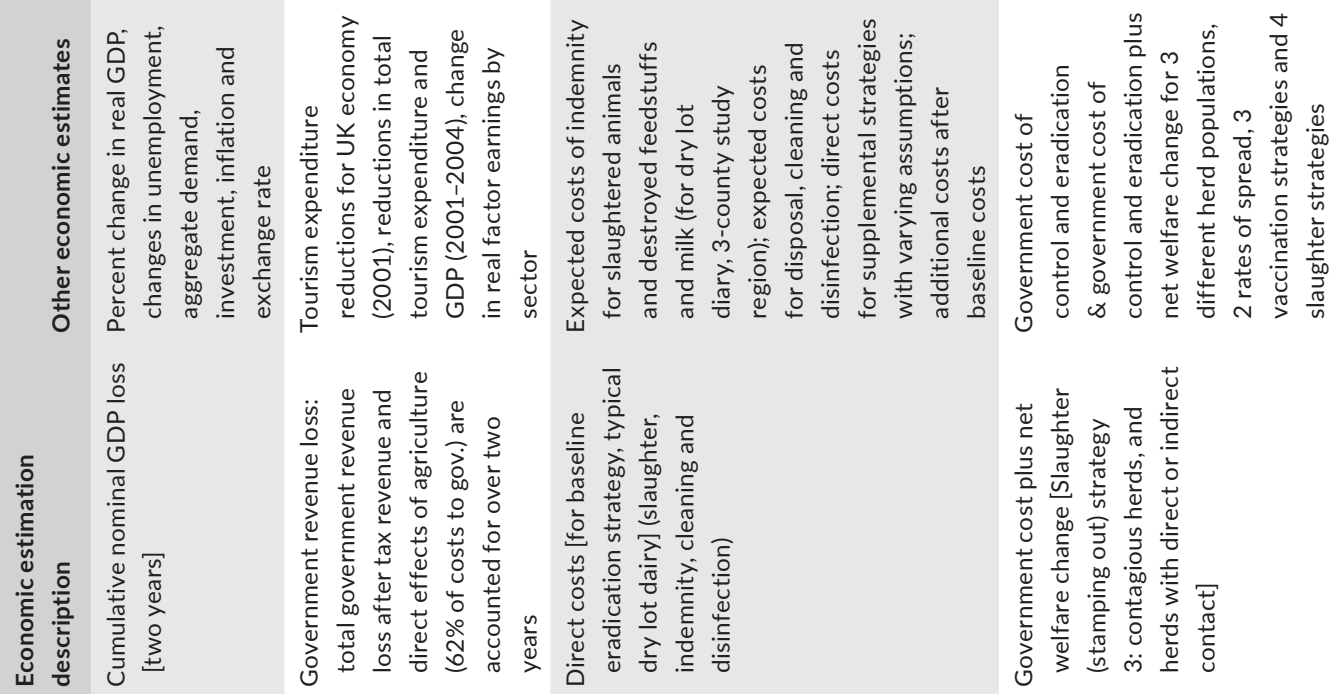

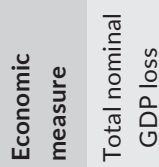

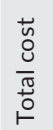

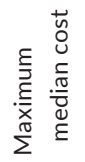

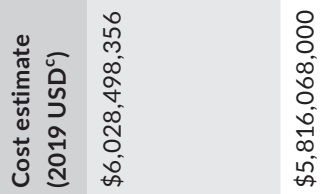

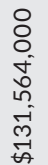

ה-

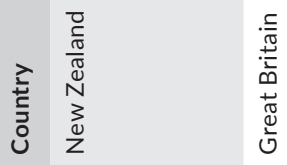

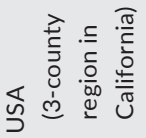

离

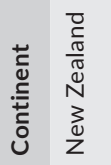

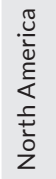

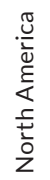

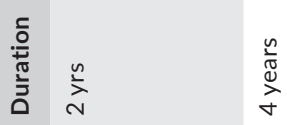

赵离

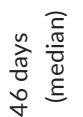

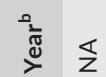

용

$\stackrel{s}{z}$

$\overleftarrow{z}$
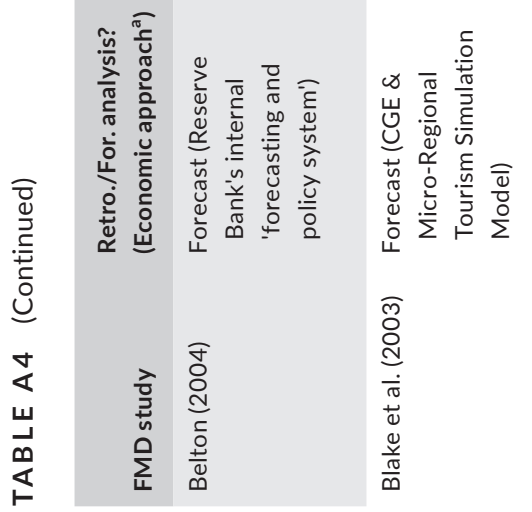

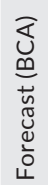

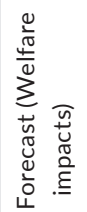

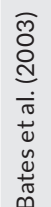

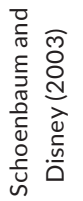



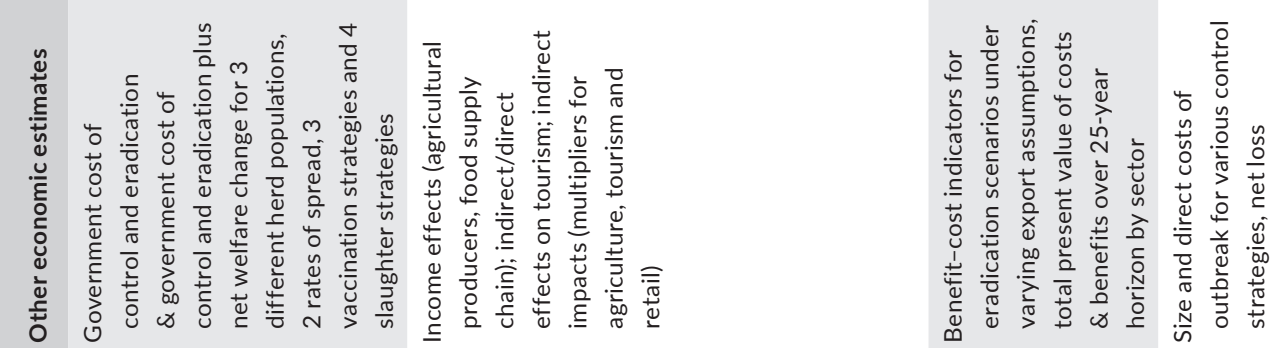

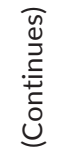
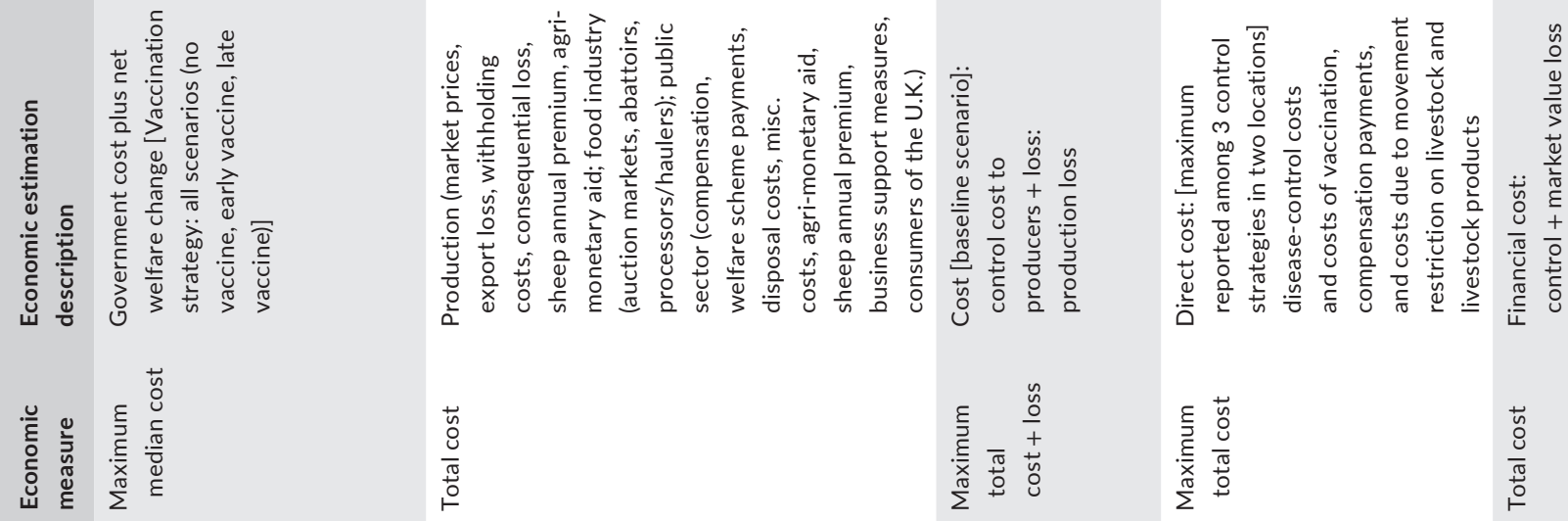

苍

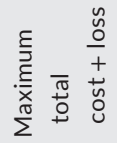

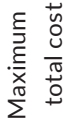

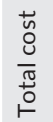

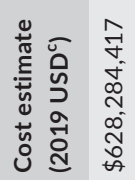

0
0
0
0
0
0
0
0
0
0
0
0

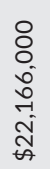

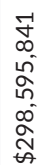

ปั

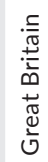

ษั

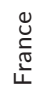

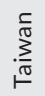

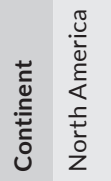

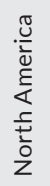

ํํㄹ

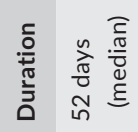

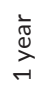

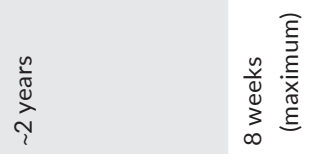

$\frac{\frac{\pi}{4}}{4}$

ข้

ํํํ

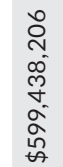

光

$\ll$

a

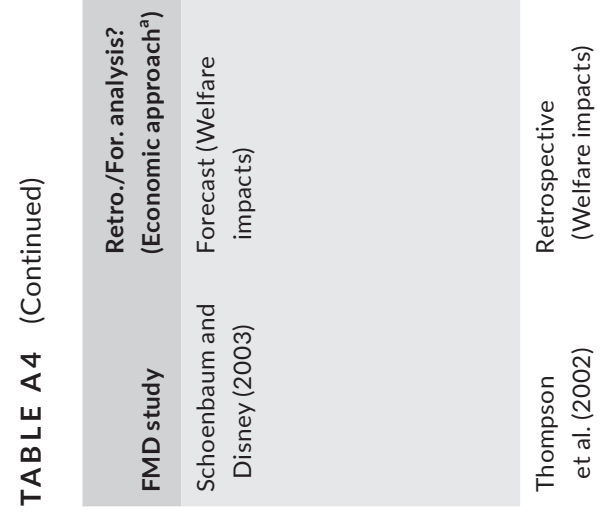

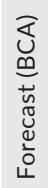

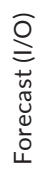

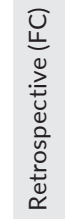

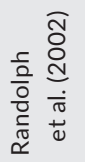

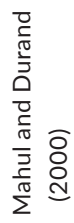

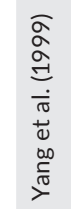




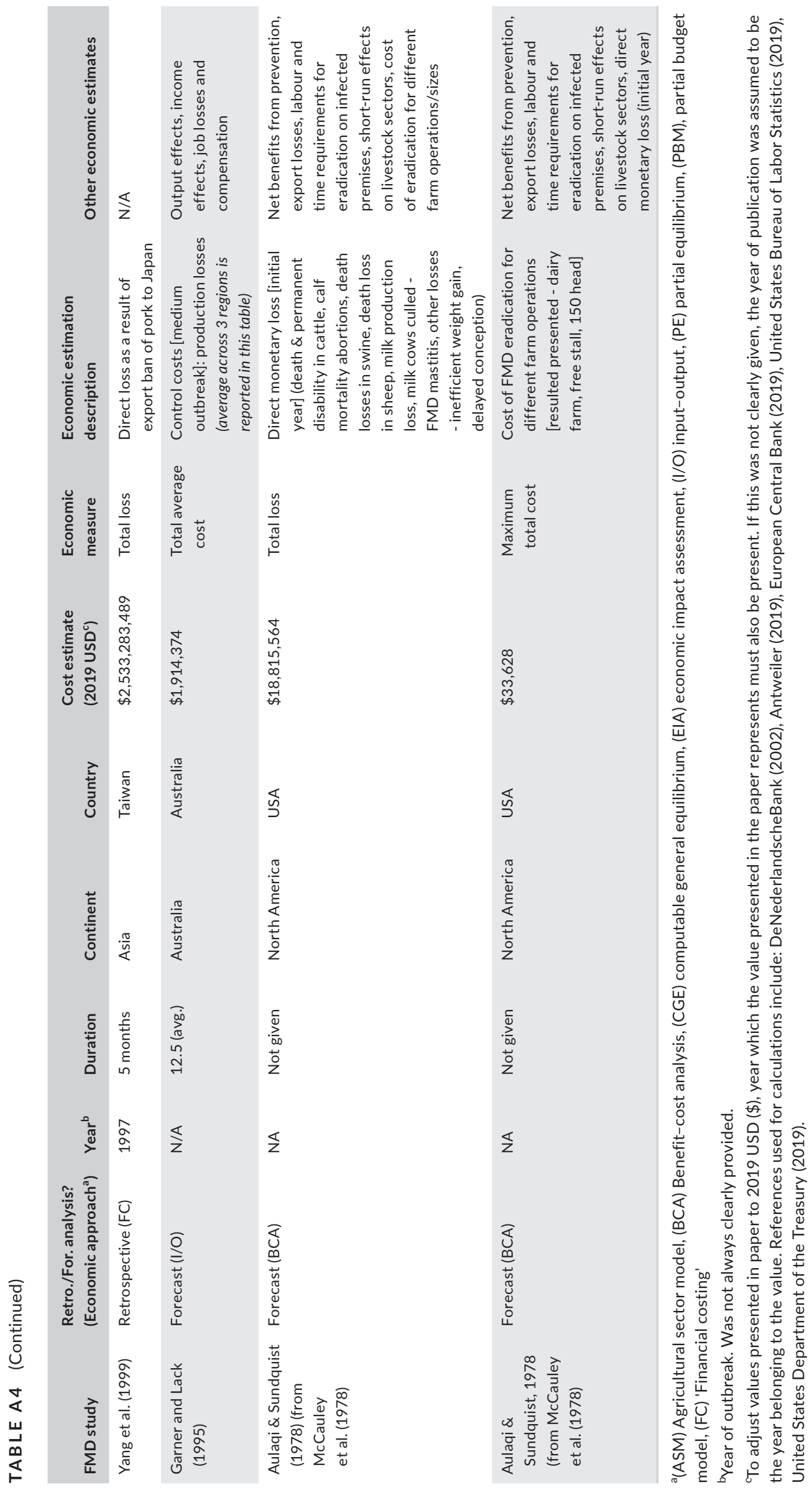


TAB LE A5 (Global) Number of outbreaks by country and livestock population estimates (head)

\begin{tabular}{|c|c|c|c|c|c|c|c|}
\hline Country Name & \# FMD & \# ASF & \# CSF & $\begin{array}{l}\text { Total \# } \\
\text { Outbreaks }\end{array}$ & $\begin{array}{l}2018 \text { Livestock } \\
\text { Pop. (head) }\end{array}$ & $\begin{array}{l}2018 \text { Swine } \\
\text { Pop. (head) }\end{array}$ & 2018 Human Pop. \\
\hline Afghanistan & 4 & 0 & 0 & 4 & $24,790,567$ & - & $37,171,921$ \\
\hline Algeria & 2 & 0 & 0 & 2 & $42,066,070$ & 2,792 & $42,228,408$ \\
\hline Angola & 3 & 0 & 0 & 3 & $4,230,156$ & $1,479,676$ & $30,809,787$ \\
\hline Argentina & 5 & 0 & 3 & 8 & $26,123,915$ & $6,778,976$ & $44,361,150$ \\
\hline Armenia & 4 & 4 & 1 & 9 & $1,999,698$ & 238,197 & $2,951,745$ \\
\hline Australia & 0 & 0 & 0 & 0 & $48,579,310$ & $5,378,100$ & $24,898,152$ \\
\hline Austria & 1 & 0 & 2 & 3 & $6,798,064$ & $5,151,074$ & $8,891,388$ \\
\hline Azerbaijan & 2 & 2 & 0 & 4 & $8,406,305$ & 9,220 & $9,949,537$ \\
\hline Belgium & 1 & 3 & 3 & 7 & $12,827,789$ & $11,230,544$ & $11,482,178$ \\
\hline Belize & 0 & 0 & 1 & 1 & 54,759 & 39,003 & 383,071 \\
\hline Benin & 9 & 9 & 0 & 18 & $2,321,858$ & 207,606 & $11,485,044$ \\
\hline Bhutan & 10 & 0 & 7 & 17 & 229,165 & 19,185 & 754,388 \\
\hline Bolivia & 9 & 0 & 7 & 16 & $6,753,435$ & $2,145,000$ & $11,353,142$ \\
\hline $\begin{array}{l}\text { Bosnia and } \\
\text { Herz. }\end{array}$ & 0 & 0 & 8 & 8 & 754,826 & 101,509 & $3,323,925$ \\
\hline Botswana & 14 & 2 & 0 & 16 & 974,861 & 13,006 & $2,254,068$ \\
\hline Cameroon & 9 & 9 & 0 & 18 & $7,486,838$ & $1,103,239$ & $25,216,267$ \\
\hline Canada & 0 & 0 & 0 & 0 & $26,942,592$ & $21,561,500$ & $37,074,562$ \\
\hline $\begin{array}{l}\text { Central African } \\
\text { Rep. }\end{array}$ & 5 & 4 & 0 & 9 & $3,052,998$ & 616,519 & $4,666,368$ \\
\hline Chad & 8 & 6 & 0 & 14 & $28,238,491$ & 79,898 & $15,477,729$ \\
\hline Chile & 1 & 0 & 1 & 2 & $7,746,152$ & $5,011,692$ & $18,729,160$ \\
\hline China & 25 & 4 & 16 & 45 & $1,090,792,328$ & $694,540,656$ & $1,427,647,786$ \\
\hline Colombia & 13 & 0 & 9 & 22 & $14,282,063$ & $4,001,545$ & $49,661,048$ \\
\hline Congo & 0 & 4 & 0 & 4 & 247,485 & 47,576 & $5,244,359$ \\
\hline Costa Rica & 0 & 0 & 2 & 2 & $1,768,731$ & 862,448 & $4,999,441$ \\
\hline Cote d'Ivoire & 7 & 6 & 0 & 13 & $1,786,867$ & 233,117 & $25,069,230$ \\
\hline Croatia & 1 & 0 & 6 & 7 & $2,606,234$ & $1,567,200$ & $4,156,405$ \\
\hline Cuba & 0 & 1 & 6 & 7 & $5,759,300$ & $4,068,300$ & $11,338,134$ \\
\hline Cyprus & 1 & 0 & 0 & 1 & $1,254,596$ & 560,255 & $1,189,265$ \\
\hline Czech Rep. & 1 & 1 & 4 & 6 & $3,311,974$ & $2,413,685$ & $10,665,677$ \\
\hline $\begin{array}{l}\text { Dem. Rep. } \\
\text { Congo }\end{array}$ & 0 & 4 & 0 & 4 & $2,503,101$ & 541,811 & $84,068,091$ \\
\hline $\begin{array}{l}\text { Dem. Rep. } \\
\text { Korea }\end{array}$ & 3 & 1 & 0 & 4 & $7,042,121$ & $2,611,312$ & $25,549,604$ \\
\hline
\end{tabular}


TABLE A5 (Continued)

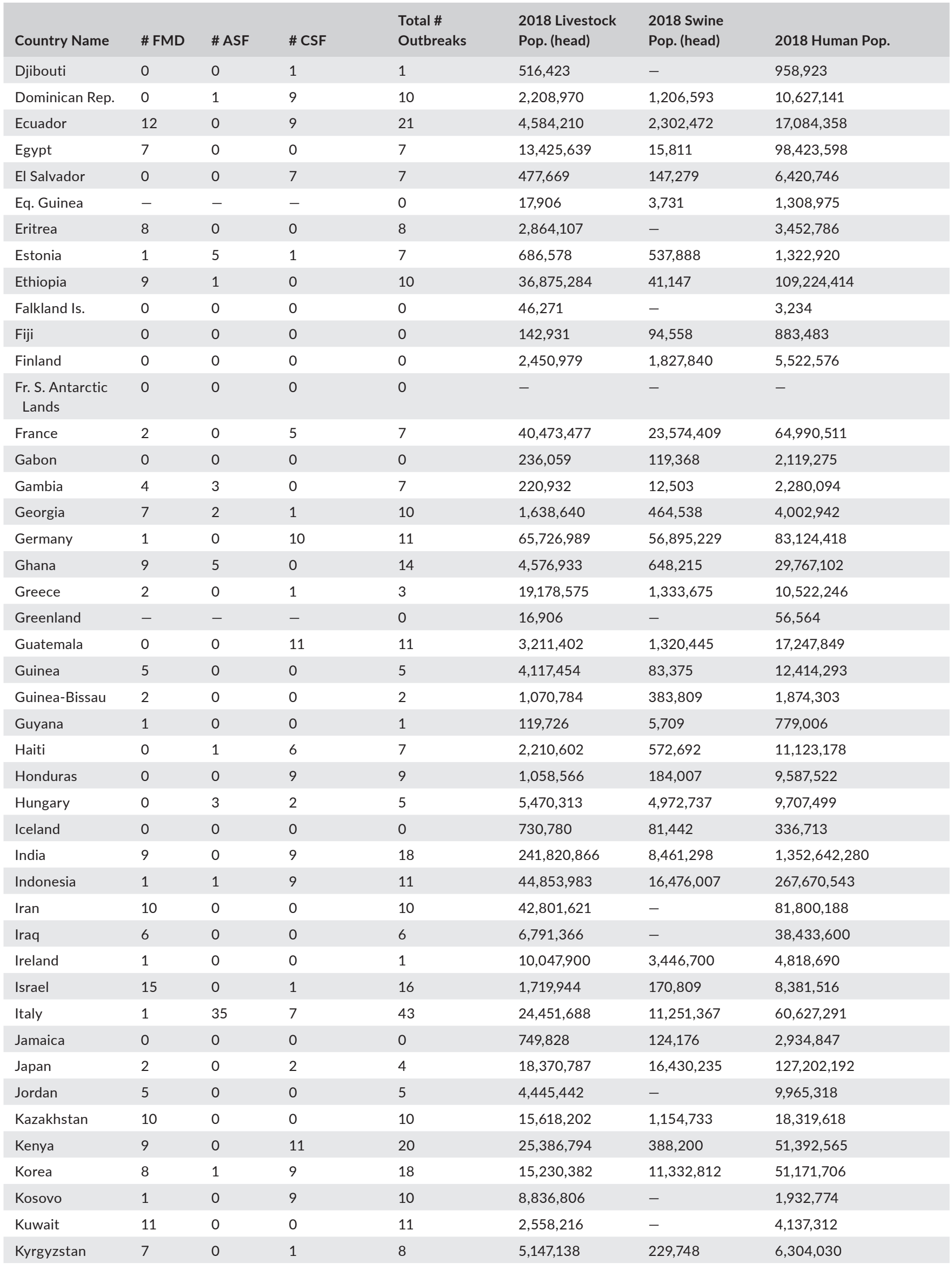


TABLE A5 (Continued)

\begin{tabular}{|c|c|c|c|c|c|c|c|}
\hline Country Name & \# FMD & \# ASF & \# CSF & $\begin{array}{l}\text { Total \# } \\
\text { Outbreaks }\end{array}$ & $\begin{array}{l}2018 \text { Livestock } \\
\text { Pop. (head) }\end{array}$ & $\begin{array}{l}2018 \text { Swine } \\
\text { Pop. (head) }\end{array}$ & 2018 Human Pop. \\
\hline Lao PDR & 10 & 1 & 8 & 19 & $3,168,232$ & $2,538,393$ & $7,061,507$ \\
\hline Lebanon & 11 & 0 & 0 & 11 & $1,237,385$ & 10,855 & $6,859,408$ \\
\hline Lesotho & 0 & 0 & 0 & 0 & $1,069,171$ & 71,429 & $2,108,328$ \\
\hline Libya & 6 & 0 & 0 & 6 & $5,919,019$ & - & $6,678,559$ \\
\hline Lithuania & 1 & 6 & 3 & 10 & $1,430,142$ & 892,692 & $2,801,264$ \\
\hline Luxembourg & 0 & 0 & 6 & 6 & 245,148 & 159,924 & 604,245 \\
\hline Macedonia & 1 & 0 & 7 & 8 & $1,156,435$ & 145,000 & $2,082,957$ \\
\hline Madagascar & 0 & 7 & 9 & 16 & $5,141,526$ & 932,251 & $26,262,313$ \\
\hline Mauritania & 8 & 0 & 0 & 8 & $8,362,146$ & - & $4,403,313$ \\
\hline Mexico & 0 & 0 & 10 & 10 & $36,743,298$ & $18,526,707$ & $126,190,788$ \\
\hline Moldova & 0 & 8 & 0 & 8 & $1,720,287$ & 740,465 & $3,364,496$ \\
\hline Mongolia & 11 & 1 & 6 & 18 & $23,239,008$ & 13,771 & $3,170,216$ \\
\hline Montenegro & - & - & - & 0 & 289,948 & 34,101 & 627,809 \\
\hline Morocco & 5 & 0 & 0 & 5 & $18,794,043$ & 12,868 & $36,029,093$ \\
\hline Mozambique & 9 & 9 & 0 & 18 & $5,250,678$ & $2,279,523$ & $29,496,004$ \\
\hline Myanmar & 14 & 1 & 7 & 22 & $25,369,278$ & $12,506,464$ & $53,708,320$ \\
\hline Nicaragua & 0 & 0 & 8 & 8 & $1,834,069$ & 235,600 & $6,465,501$ \\
\hline Niger & 9 & 0 & 0 & 9 & $14,487,751$ & 33,480 & $22,442,822$ \\
\hline Nigeria & 8 & 12 & 0 & 20 & $55,522,573$ & $6,306,518$ & $195,874,683$ \\
\hline Norway & 0 & 0 & 0 & 0 & $3,658,387$ & $1,703,823$ & $5,337,962$ \\
\hline Oman & 8 & 0 & 0 & 8 & $3,840,898$ & - & $4,829,473$ \\
\hline Pakistan & 8 & 0 & 0 & 8 & $81,482,184$ & - & $212,228,286$ \\
\hline Palestine & 12 & 0 & 0 & 12 & $1,315,008$ & - & $4,862,979$ \\
\hline Panama & 0 & 0 & 0 & 0 & $1,066,130$ & 594,917 & $4,176,869$ \\
\hline $\begin{array}{l}\text { Papua New } \\
\text { Guinea }\end{array}$ & 0 & 0 & 0 & 0 & $2,042,330$ & $2,014,729$ & $8,606,323$ \\
\hline Paraguay & 5 & 0 & 1 & 6 & $4,722,134$ & $2,315,343$ & $6,956,066$ \\
\hline Peru & 5 & 0 & 9 & 14 & $8,688,064$ & $3,090,907$ & $31,989,260$ \\
\hline Philippines & 9 & 1 & 9 & 19 & $32,353,557$ & $27,712,985$ & $106,651,394$ \\
\hline Poland & 0 & 9 & 1 & 10 & $27,092,284$ & $22,779,899$ & $37,921,592$ \\
\hline Portugal & 1 & 9 & 1 & 11 & $7,468,718$ & $5,550,127$ & $10,256,193$ \\
\hline Puerto Rico & 0 & 0 & 0 & 0 & 203,382 & 62,137 & $3,039,596$ \\
\hline Qatar & 6 & 0 & 0 & 6 & 999,725 & - & $2,781,682$ \\
\hline Romania & 0 & 5 & 4 & 9 & $22,635,877$ & $5,579,000$ & $19,506,114$ \\
\hline
\end{tabular}


TABLE A5 (Continued)

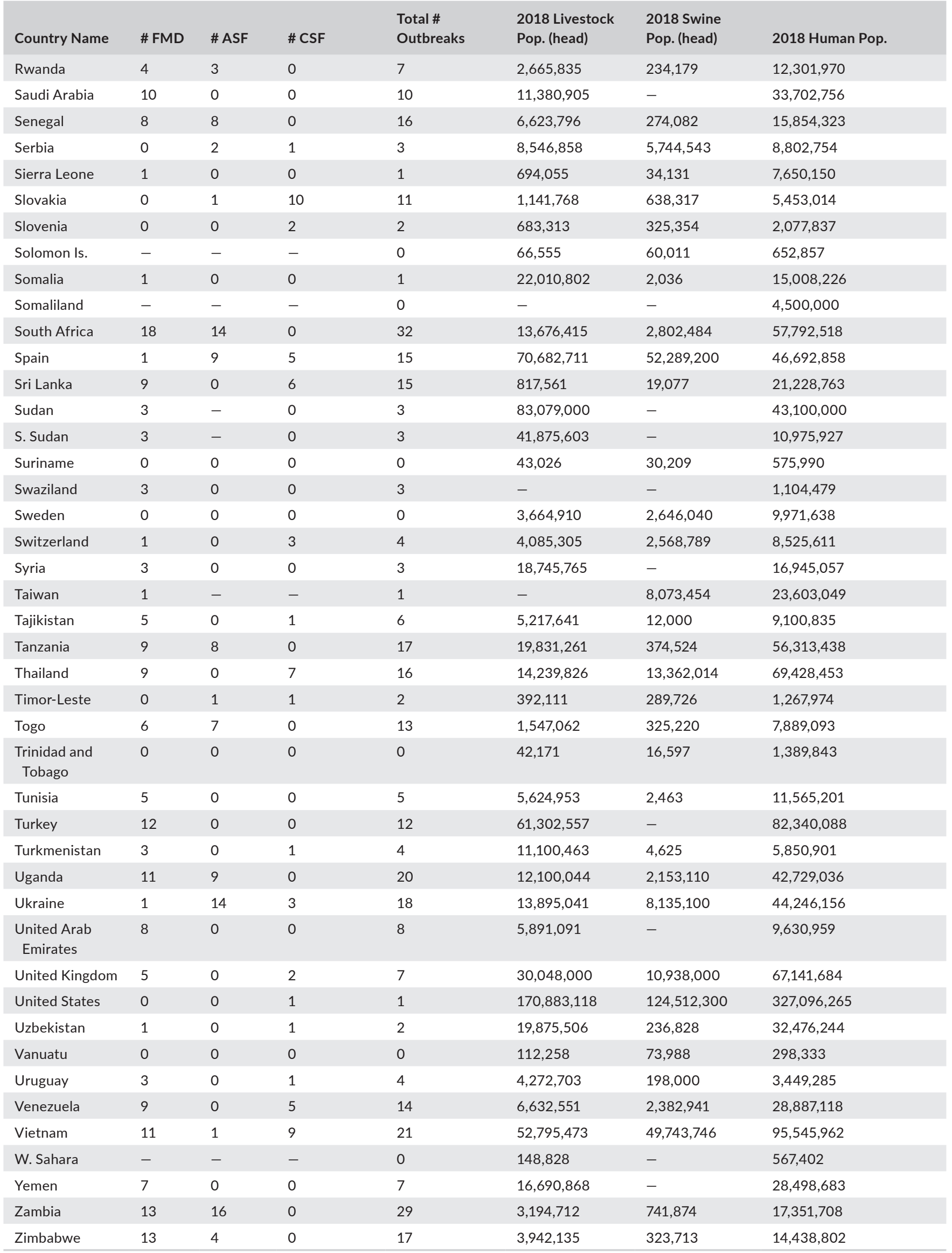

